6-1992

\title{
Cultural Resources Monitoring/Survey of a JTF-6 Action, Van Horn, Texas Sector
}

Frank Winchell

Geo-Marine, Inc.

George Brown

Geo-Marine, Inc.

Maynard B. Cliff

Geo-Marine, Inc.

Sherrian K. Edwards

Geo-Marine, Inc.

Follow this and additional works at: https://scholarworks.sfasu.edu/ita

Part of the American Material Culture Commons, Archaeological Anthropology Commons, Environmental Studies Commons, Other American Studies Commons, Other Arts and Humanities Commons, Other History of Art, Architecture, and Archaeology Commons, and the United States History Commons

Tell us how this article helped you.

This Article is brought to you for free and open access by the Center for Regional Heritage Research at SFA ScholarWorks. It has been accepted for inclusion in Index of Texas Archaeology: Open Access Gray Literature from the Lone Star State by an authorized editor of SFA ScholarWorks. For more information, please contact cdsscholarworks@sfasu.edu. 
Cultural Resources Monitoring/Survey of a JTF-6 Action, Van Horn, Texas Sector

Creative Commons License

(ब) $(1) \Theta$

This work is licensed under a Creative Commons Attribution-NonCommercial-No Derivative Works 4.0 International License. 


\section{CULTURAL RESOURCES MONITORING/SURVEY OF A JTF-6 ACTION, VAN HORN, TEXAS SECTOR}

by

Frank Winchell

George Brown

Maynard B. Cliff

Sherrian K. Edwards

Principal Investigator: Duane E. Peter

\section{MISCELLANEOUS REPORT OF INVESTIGATIONS,}

Number 33

Prepared for:

Fort Worth District

U.S. Army Corps of Engineers

Fort Worth, Texas

Contract No. DACA63-90-D-0061

by

Geo-Marine, Inc.

550 Fifteenth Street

Plano, Texas

June 1992 


\begin{tabular}{|c|c|c|c|c|c|}
\hline \multicolumn{2}{|l|}{$\begin{array}{l}\text { 1a. REPORT SECURITY CLASSIFICATION } \\
\text { Unclassified }\end{array}$} & \multicolumn{4}{|c|}{ 1b. RESTRICTIVE MARKINGS } \\
\hline \multicolumn{2}{|l|}{ 2a. SECURITY CLASSIFICATION AUTHORITY } & \multicolumn{4}{|c|}{$\begin{array}{l}\text { 3. DISTRIBUTION/AVAILABILITY OF REPORT } \\
\text { Approved for public release }\end{array}$} \\
\hline $\begin{array}{l}\text { 4. PERFORMING ORGANIZATION REPORT N } \\
\text { Miscellaneous Report of Invest }\end{array}$ & $\begin{array}{l}\text { MBERS } \\
\text { ations No. } 33\end{array}$ & \multicolumn{4}{|c|}{ 5. MONITORING ORGANIZATION REPORT NUMBER(S) } \\
\hline $\begin{array}{l}\text { 6a. NAME OF PERFORMING ORGANIZATION } \\
\text { Geo-Manine Inc. }\end{array}$ & $\begin{array}{l}\text { 6b. OFFICE SYMBOL } \\
\text { (if applicable) }\end{array}$ & \multicolumn{4}{|c|}{$\begin{array}{l}\text { 7a. NAME OF MONITORING ORGANIZATION } \\
\text { US Army Corps of Engineers, Fort Worth District }\end{array}$} \\
\hline \multicolumn{2}{|c|}{550 E. Fifteenth Street / Plano, Texas / 75074} & \multicolumn{4}{|c|}{$\begin{array}{l}\text { 7b. ADDRESS (City, State, and Zip Code) } \\
\text { PO Box } 17300 \\
\text { Fort Worth, Texas } 76102\end{array}$} \\
\hline $\begin{array}{l}\text { 8a. NAME OF FUNDING/SPONSORING } \\
\text { ORGANIZATION } \\
\text { US Army Corps of Engineers, } \\
\text { Fort Worth District }\end{array}$ & $\begin{array}{l}\text { 8b. OFFICE SYMBOL } \\
\text { (if applicable) }\end{array}$ & \multicolumn{4}{|c|}{$\begin{array}{l}\text { 9. PROCUREMENT INSTRUMENT ID NUMBER } \\
\text { DACA63-D-0061, Delivery Order No. } 0012\end{array}$} \\
\hline \multirow{2}{*}{\multicolumn{2}{|c|}{ 8c. ADDRESS (City, State, and Zip Code) }} & \multicolumn{4}{|c|}{ 10. SOURCE OF FUNDING NUMBERS } \\
\hline & & $\begin{array}{l}\text { PROGRAM } \\
\text { ELEMENT NO. }\end{array}$ & $\begin{array}{l}\text { PROJECT } \\
\text { NO. }\end{array}$ & $\begin{array}{l}\text { TASK } \\
\text { NO. }\end{array}$ & $\begin{array}{l}\text { WORK UNIT } \\
\text { ACCESSION NO. }\end{array}$ \\
\hline
\end{tabular}

11. TITLE (Include Security Classification)

Cultural Resources Monitoring / Survey of a JTF-6 Action, Van Horn, Texas Sector

12a. PERSONAL AUTHOR(S)

Frank Winchell, George Brown, Maynard B. Cliff, and Sherrian K. Edwards

\begin{tabular}{|c|c|c|c|}
\hline $\begin{array}{l}\text { 13a. TYPE OF REPORT } \\
\text { Final Report }\end{array}$ & $\begin{array}{l}\text { 13b. TIME COVERED } \\
\text { FROM } \_ \text {- } / 91 \text { TO } \quad 6 / 92\end{array}$ & $\begin{array}{l}\text { 14. DATE OF REPORT (Year, Month, Day) } \\
\text { June } 1992\end{array}$ & $\begin{array}{l}\text { 15. PAGE COUNT } \\
89\end{array}$ \\
\hline
\end{tabular}

16. SUPPLEMENTARY NOTATION

17. COSATI CODES

\begin{tabular}{l|l|l} 
FIELD & GROUP & SUB-GROUP \\
\hline
\end{tabular}

05

06
18. SUBJECT TERMS (Continue on reverse if necessary and identify by block number)

Archeology / Cultural Resources in Culberson, Jeff Davis, Hudspeth, and Presidio counties, Texas

\section{ABSTRACT (Continue on reverse if necessary and identify by block number)}

This report presents the results of the cultural resources monitoring and survey activities connected with a Department of Defense (DOD) Joint Task Force Six (JTF-6) project encompassing the area in southern Hudspeth and Culberson, western Jeff Davis and northern Presidio counties, Texas. These cultural resource activities were prompted by road improvement activities initiated by the U.S. Border Patrol. The road improvement activities were designed to aid the U.S. Border Patrol in their battle against illegal drug trade and smuggling operations along the U.S.-Mexico border. Geo-Marine, Inc. conducted the survey as part of an indefinite delivery contract with the Fort Worth District of the U.S. Army Corps of Engineers. The survey and monitoring were tailored to focus only on those areas to be disturbed by road repair activities and to identify cultural resource sites which were to be avoided during such activities.

The survey and monitoring resulted in the recording of thirty-one (31) cultural resource properties--all dating to the prehistoric era. Of the 31 sites recorded, 24 are surficial sites with only minimum depth and no evidence of stratified deposits. Some are quite extensive horizontally, but lack of vertical depth, subsistence data, and features limit their research value. Consequently, none of these sites have any potential to contribute data important to our understanding of the prehistory of the region and would not be considered eligible for nomination to the National Register of Historic Places. The remaining seven sites are of unknown status due to the possibility that some depth of deposit may be present on some or all of these sites. A feature (possible hearth) has also been located on one of these sites. At this time, no further work is recommended for these seven sites so long as they are not affected by any other road construction activities. However, if further road improvement is to impact any of these seven sites, then it is recommended that they be tested to determine if buried materials exist.

20. DISTRIBUTION/AVAILABILITY OF ABSTRACT DUNCLASSIFIED/UNLIMITED 囚SAME AS RPT. 口DTIC USERS 22a. NAME OF RESPONSIBLE INDIVIDUAL Mr. Jay Newman

\section{ABSTRACT SECURITY CLASSIFICATION Unclassified}

22b. TELEPHONE (Include Area Code) 22c. OFFICE SYMBOL 817/334-2625 CESWF-PL-RC 


\section{CONTRACT DATA}

The preparation of this document was accomplished under Contract No. DACA63-90-D-0061, Delivery Order No. 0012, with the U.S. Army Corps of Engineers, Fort Worth District, P.O. Box 17300, Fort Worth, Texas 76102 . 


\section{MANAGEMENT SUMMARY}

This report presents the results of cultural resources monitoring and survey activities connected with a Department of Defense (DOD) Joint Task Force Six (JTF-6) project in southern Hudspeth and Culberson, western Jeff Davis, and northern Presidio Counties, Texas. These cultural resource activities were prompted by road improvement activities initiated by the U.S. Border Patrol. The road improvement activities were designed to aid the U.S. Border Patrol in their battle against illegal drug trade and smuggling operations along the U.S.-Mexico border. Geo-Marine, Inc. conducted the survey as part of an indefinite delivery contract with the Fort Worth District of the U.S. Army Corps of Engineers. The survey and monitoring were tailored to focus only on those areas to be disturbed by road repair activities and to identify cultural resource sites which were to be avoided during such activities.

The survey and monitoring resulted in the recording of thirty-one (31) cultural resource properties--all dating to the prehistoric era. Of the 31 sites recorded, 24 are surficial sites with only minimum depth and no evidence of stratified deposits. Some are quite extensive horizontally, but lack of vertical depth, subsistence data, and features limits their research value. Consequently, none of these sites have any potential to contribute data important to our understanding of the prehistory of the region and would not be considered eligible for nomination to the National Register of Historic Places. The remaining seven sites are of unknown status due to the possibility that some depth of deposit may be present on some or all of these sites. A feature (possible hearth) has also been located on one of these sites. At this time, no further work is recommended for these seven sites so long as they are not affected by any other road construction activities. However, if future road improvement work is to impact any of these seven sites, then it is recommended that they be tested to determine if additional buried archeological material exists. 


\section{TABLE OF CONTENTS}

Management Summary $\ldots \ldots \ldots \ldots \ldots \ldots \ldots \ldots \ldots \ldots \ldots \ldots \ldots \ldots \ldots \ldots \ldots$

Acknowledgements $\ldots \ldots \ldots \ldots \ldots \ldots \ldots \ldots \ldots \ldots \ldots \ldots \ldots \ldots \ldots \ldots \ldots \ldots$

Introduction $\ldots \ldots \ldots \ldots \ldots \ldots \ldots \ldots \ldots \ldots \ldots \ldots \ldots \ldots \ldots \ldots \ldots \ldots \ldots \ldots \ldots \ldots$

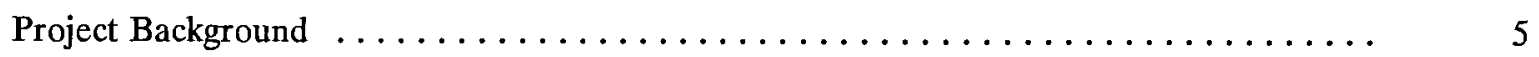

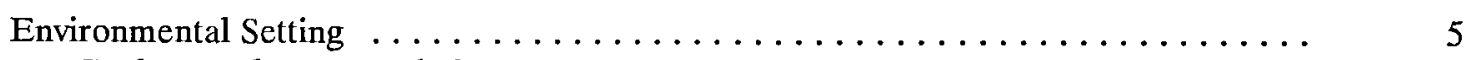

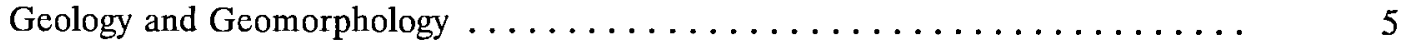

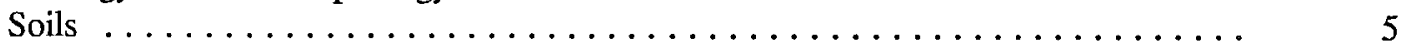

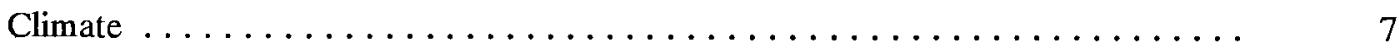

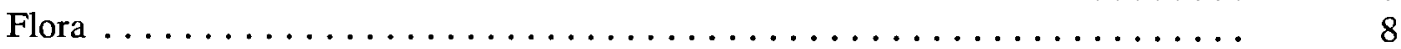

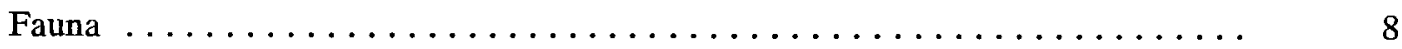

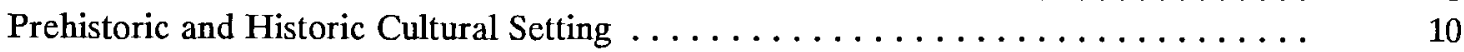

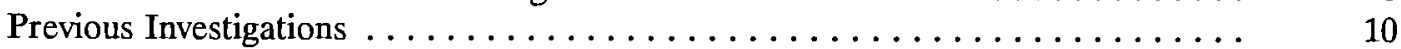

Prehistoric . . . . . . . .

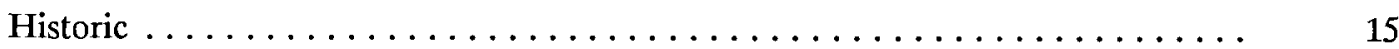

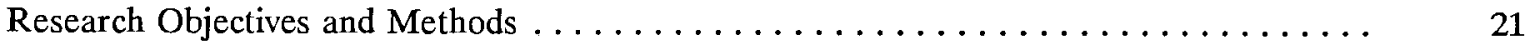

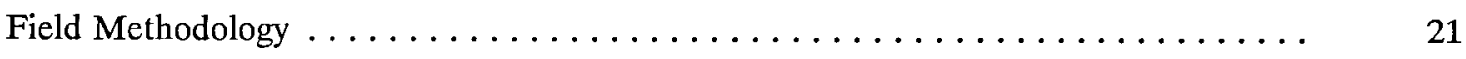

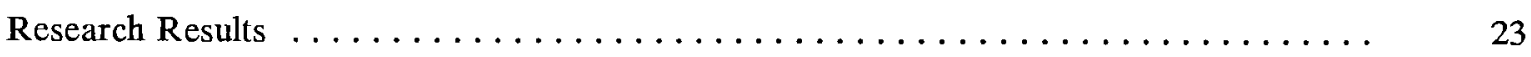

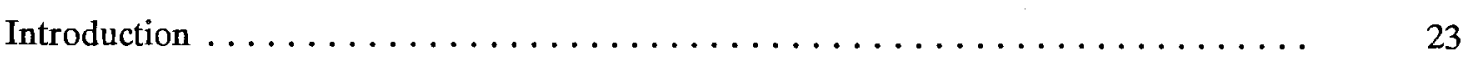

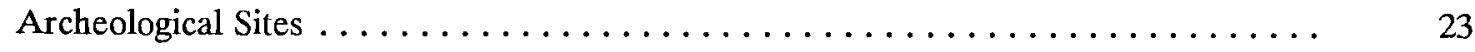

Site Assessment and Recommendations . . . . . . . .

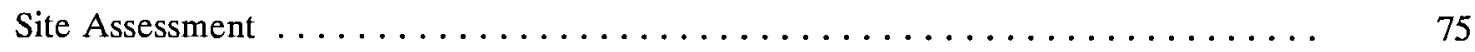

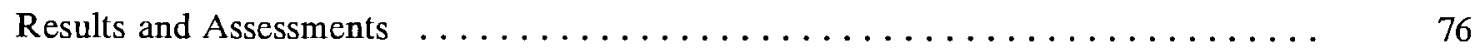

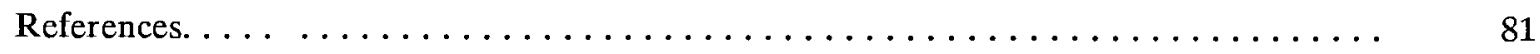

Appendix A - Curated Material from JTF-6 Van Horn 



\section{LIST OF FIGURES}

No.

$\underline{\text { Page }}$

1 The general location of the JTF-6 Van Horn project area ............. 2

2 Major vegetative regions of the Trans-Pecos (after Schmidly 1977) . . . . . . . 9

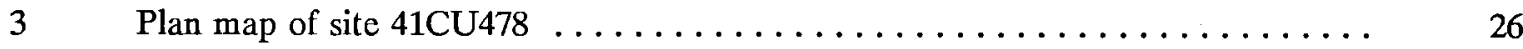

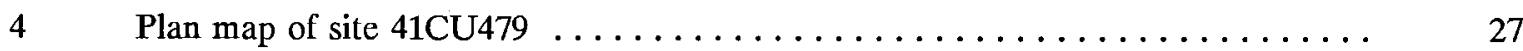

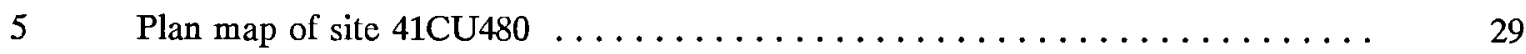

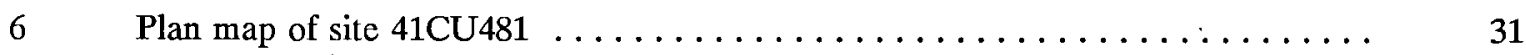

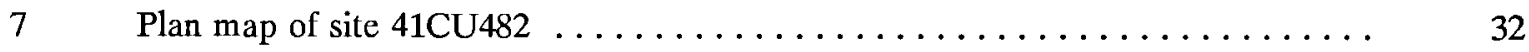

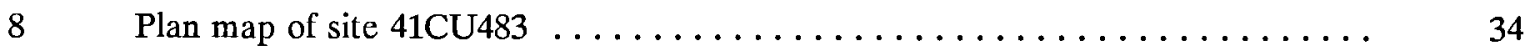

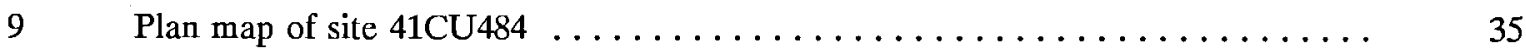

$10 \quad$ Plan map of site $41 \mathrm{CU} 485 \ldots \ldots \ldots \ldots \ldots \ldots \ldots \ldots \ldots \ldots \ldots \ldots \ldots \ldots \ldots \ldots \ldots$

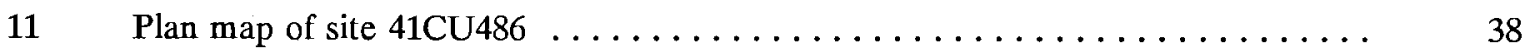

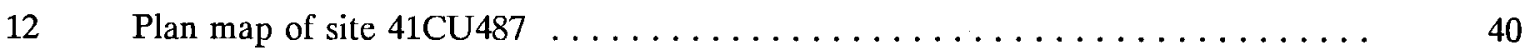

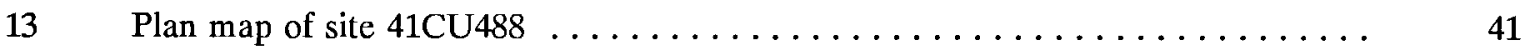

14 Projectile points from $41 \mathrm{CU} 488 \ldots \ldots \ldots \ldots \ldots \ldots \ldots \ldots \ldots \ldots \ldots \ldots \ldots$

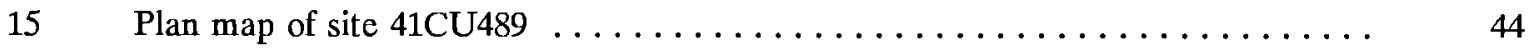

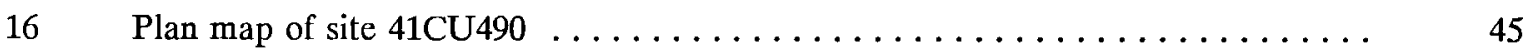

$17 \quad$ Plan map of site $41 \mathrm{CU} 491 \ldots \ldots \ldots \ldots \ldots \ldots \ldots \ldots \ldots \ldots \ldots \ldots \ldots \ldots \ldots$

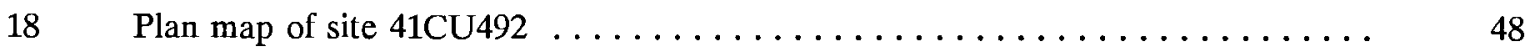

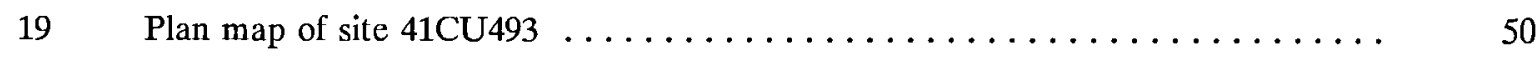

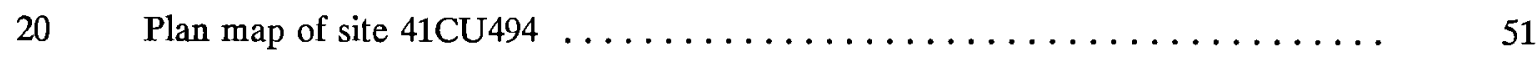

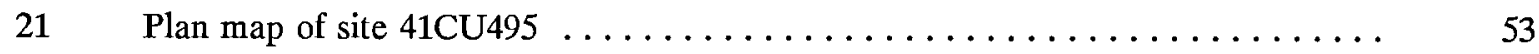

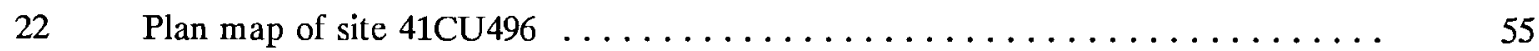

23 Plan map of possible feature on site $41 \mathrm{CU} 496 \ldots \ldots \ldots \ldots \ldots \ldots \ldots \ldots$

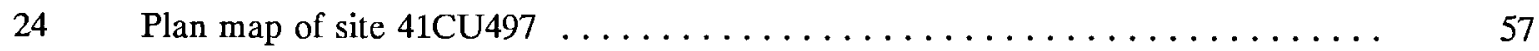




\section{List of Figures}

(cont'd)

No.

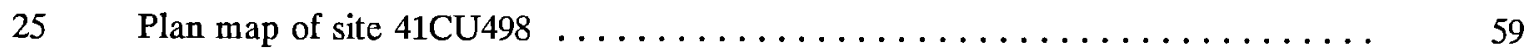

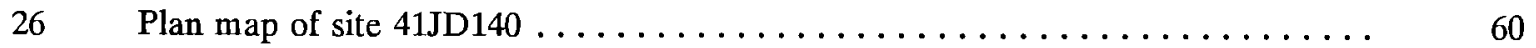

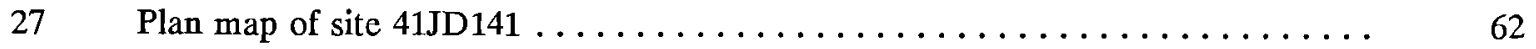

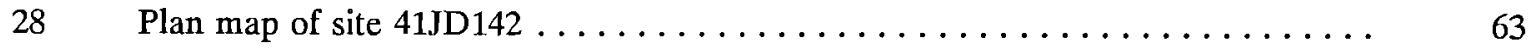

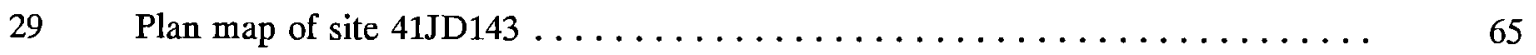

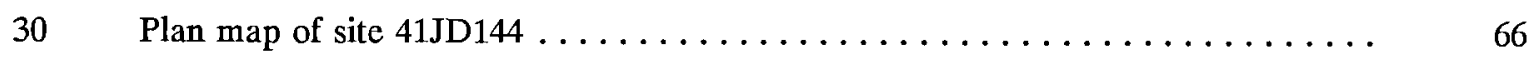

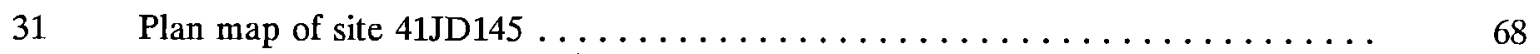

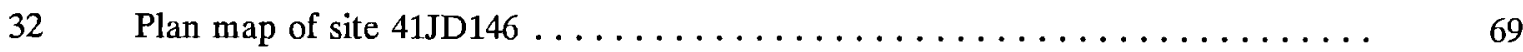

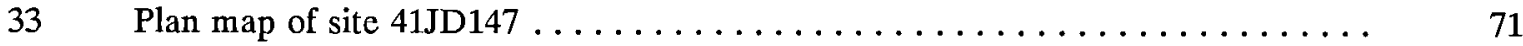

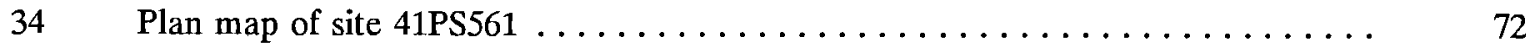

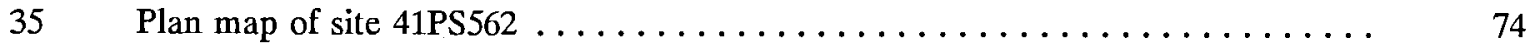

\section{List of Attachments}

1 Locations of recorded sites along the Van Horn Sector. For the protection of sensitive site location information, this attachment may be obtained only through the U.S. Army Corps of Engineers, Worth District. 


\section{LIST OF TABLES}

No.

1 Water-bearing Characteristics of Geologic Units that are Significant Sources

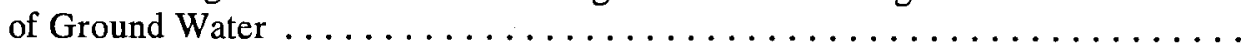

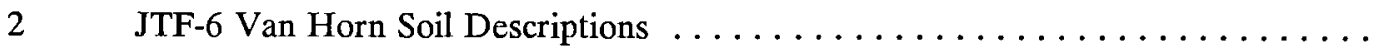

3 GMI Field Number/Texas State Site Number Correlation, JTF-6/Van

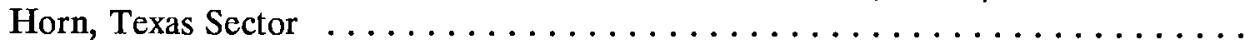

$4 \quad$ Utilization and Estimated Period of Occupation of Sites Recorded during the JTF-6 Van Horn Road Repair Project, 1991 . . . . . . . . . . . . . . .

$5 \quad$ NRHP Assessment of Cultural Resource Sites for the JTF-6 Van Horn Road

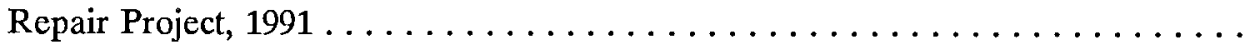





\section{ACKNOWLEDGEMENTS}

We would like to express our appreciation to the many individuals and organizations who contributed to the successful completion of this project. The U.S. Border Patrol, especially Chief Agent Amaro Munoz, was particularly helpful in providing access to the project area and directing our attention to the unique cultural resources of the region. Local avocational archeologists, Mr. H.O. Haynes and Mr. Jack Hedrick, also graciously shared their knowledge of the area with our personnel. As usual, such interaction contributed to a better understanding of the regional archeology. Mr. Jay Newman, our primary contact with the U.S. Army Corps of Engineers, Fort Worth District, provided excellent administrative guidance and constructive comments.

In the field, the experience and dedication of Mr. George Brown, Field Supervisor, and Mr. Steven Hunt, Mr. Robert Perales, and Mr. Gary Shaw, as Field Assistants, were essential for the protection of the sites through avoidance. Mr. Frank Winchell, Mr. George Brown, Dr. Maynard Cliff, and Ms. Sherrian Edwards were the primary contributors to the report. Mr. Charles Suhler drafted the site maps while Ms. Kim Kane, Ms. Sharlene Allday, and Mr. Steven Hunt were responsible for editing and final report production. Ms. Patricia Knowles, Office Manager, was instrumental in formatting the final report. 


\section{CHAPTER 1}

\section{INTRODUCTION}

This report presents the results of a cultural resource monitoring and survey assessment of the area to be affected by a Department of Defense (DOD) Joint Task Force Six (JTF-6) action in southern Hudspeth and Culberson, western Jeff Davis, and northern Presidio Counties, Texas (Figure 1). The general boundary of the project area falls south of the town of Van Horn, just below US 10, and includes lands in and around the Van Horn Mountains and the northern part of the Sierra Vieja Mountains. The project area is bordered by the Green River on the west and Lobo Valley on the east. The surveyed roads within the Van Horn project area basically run along the lower slope edges and pass between the mountain ranges.

The JTF-6 Van Horn road repair project was conducted in response to a request by the U.S. Border Patrol to increase their effectiveness in the current battle against drug trafficking and smuggling activities. The project was intended to assist the U.S. Border Patrol in maintaining increased visibility within known high traffic areas, and includes the repair of approximately 60 miles of generally private ranch roads scattered around the Van Horn, Texas area which have been significantly disturbed by original road construction, grading/dozing, and periodic road maintenance activities in the past.

A records search revealed that at least two previously recorded archeological sites were present in the project area (41HZ280 and CM-3), with several more known within the surrounding vicinity, including the National Register site 41CU9. An initial reconnaissance survey conducted by U.S. Army Corps of Engineers (COE) personnel indicated that one of the two recorded sites within the project area (site CM-3) had been mislocated on maps and was actually outside the project area. Site 41CU9 was found to be within the project area but was over a kilometer west of the nearest road right-of-way. This site will not be affected by any of the U.S. Border Patrol road improvement activities. The remaining site, $41 \mathrm{HZ2} 20$, was also within the project area not far (within several hundred meters) of one of the road right-of-ways.

Since archeological sites have been located and recorded within the greater Van Horn area, the U.S. Army Corps of Engineers, Fort Worth District, required an archeological monitoring of the JTF-6 actions. This work was conducted in accordance with, and in partial fulfillment of, the U.S. Army/Department of Defense obligations under the National Historical Preservation Act of 1966, as amended (PL-96-515); the Archeological and Historical Preservation Act of 1974, as amended (PL-93291); the National Environmental Policy Act of 1969 (PL-90-190); Executive Order No. 11593, "Protection and Enhancement of the Cultural Environment;" and Army Regulation (AR) AR-200-2.

In September of 1991, Geo-Marine, Inc. was contracted by the U.S. Army Corps of Engineers to conduct cultural resource monitoring and survey for the JTF- 6 Van Horn road repair project. The project was restricted to previously existing border and ranch road right-of-ways. The recorded site, $41 \mathrm{HZ2} 20$, was to be avoided by any construction-related activities and reflagged (this site had been flagged initially during the COE survey). Any additional sites discovered during survey or monitoring were to be further avoided, and all construction work which could possibly impact a site was to cease immediately. New sites were to be recorded on State of Texas site forms and flagged. All survey and selective monitoring of the road repair work was to be done by one or more qualified archeologists.

The cultural resources monitoring field work was conducted between September 17 and October 14, 1991 by a crew of two archeologists. Mr. Duane Peter, Senior Archeologist of Geo-Marine, Inc., served as Principal Investigator, while Mr. George Brown served as Field Supervisor. This work was performed under Delivery Order No. 0012 of Contract No. DACA63-90-D-0061. 


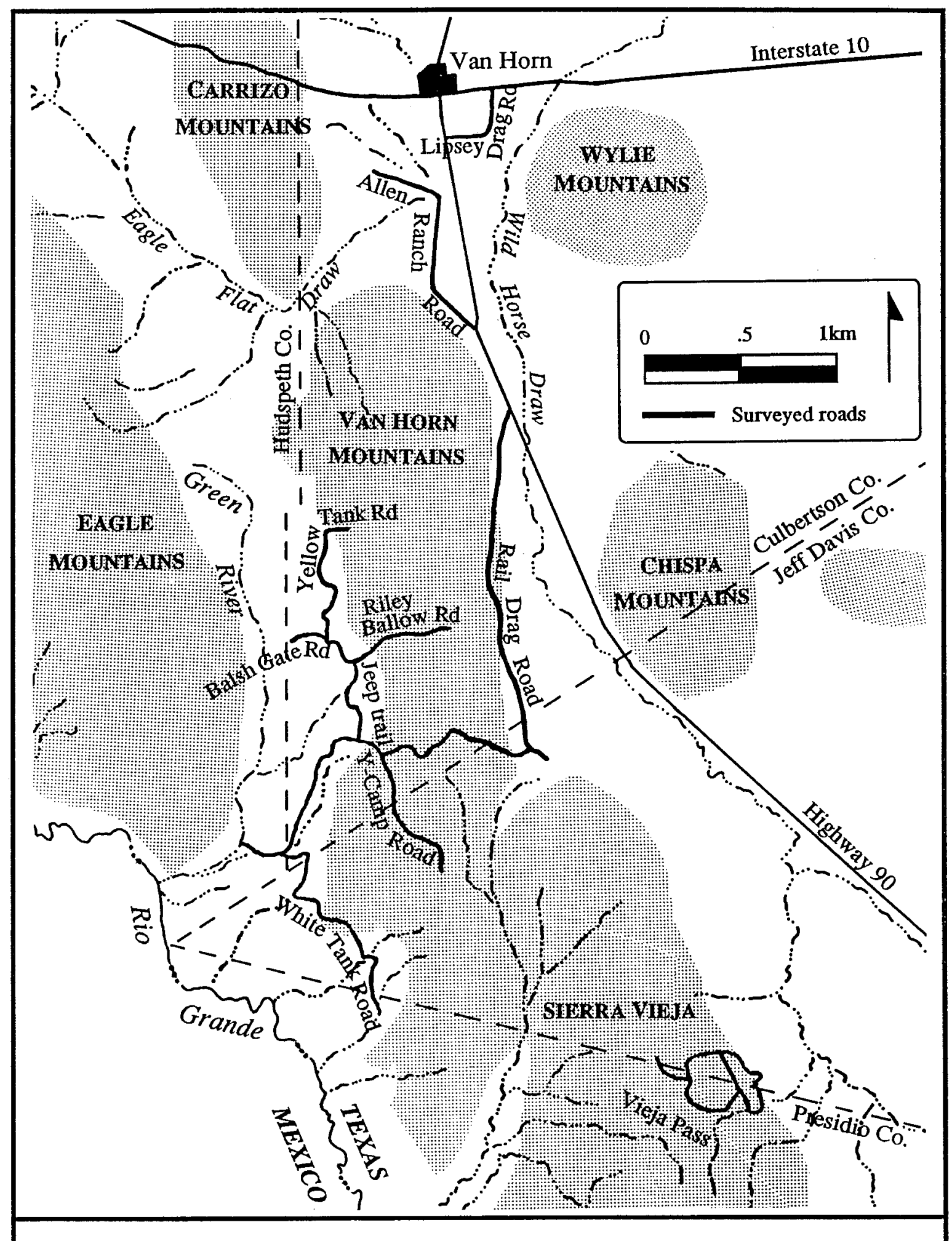

Figure 1. The general location of the JTF-6 Van Horn project area. 
Thirty-one sites were identified during the survey, and all date to the prehistoric past. Unfortunately, most of the sites could not be associated with any temporally diagnostic artifacts. The few that could, indicated that the project area was occupied during both the Archaic and Late Prehistoric periods. Since the contract scope-of-work did not include shovel testing, seven of the recorded sites are of unknown depth and may have some research value remaining, and thus presently are considered to have insufficient information available to evaluate properly their potential for inclusion on the National Register of Historic Places (NRHP). The remaining 24 sites, however, appear to be only surface manifestations overlying bedrock and thus are felt to have no research value and presently are considered to be ineligible for inclusion on the NRHP.

This report contains five chapters. The natural and cultural setting of the project area is presented in Chapter 2. Chapter 3 presents the research goals and methods for the survey and monitoring activities. Site descriptions are presented in Chapter 4. Assessment of the National Register eligibility of the recorded sites and an assessment of the need for additional investigations are presented in Chapter 5. A listing of references cited follows Chapter 5. 


\title{
CHAPTER 2
}

\section{PROJECT BACKGROUND}

\author{
Environmental Setting
}

\section{Geology and Geomorphology}

The Van Horn Project area is situated within what is generally termed the Trans-Pecos region. The Trans-Pecos consists of mountains and canyons and stretches of plateaus and plains between two relatively broad valleys; the Rio Grande on the west, and the Pecos River on the east. The project area falls within the interior subregion of the Trans-Pecos area which is characterized by true basin and range topography (Mallouf 1985:5; Hicks 1989:13). Generally, the mountains are irregular in shape, trend south and southeast, and are separated by parallel belts of lowlands or bolsons. The Rio Grande is the only permanently flowing stream in the area, and forms the border on the west and south of the project area. All other streams are ephemeral.

The geology in and around the Van Horn project area is complex, featuring evidence of many geologic processes including faulting, folding, and igneous intrusions. Exposed rocks in and around the project area range in age from Precambrian to Recent, with nearly all geologic systems being represented. The majority of rocks are of sedimentary origin; however, igneous rocks occupy a large part of Jeff Davis and Presidio Counties (Gates et al. 1980).

Unconsolidated Tertiary and Quaternary deposits fill the basins. Volcanic, volcanic-clastic, and intrusive rocks of Tertiary Age outcrop over much of the project area including parts of the Quitman, Eagle, and Van Horn Mountains. These latter deposits also comprise most of the Sierra Vieja highlands south of the Wylie Mountains and the Davis, Chinati, and Bofecillos Mountains (Gates et al. 1980). Limestone and sandstone rocks of Cretaceous age form outcrops on the southern Diablo Plateau, between the Davis and Apache Mountains and in the Van Horn Mountains. Rocks of Permian age, primarily limestone, crop out in the Wylie, Apache, Delaware, and Guadalupe Mountains and on the Diablo Plateau.

The Texas Lineament, a prominent structural feature crossing the project area along the northern side of Eagle Flat, is considered to be part of a transcontinental fracture zone by some geologists (Gates et al. 1980). At Eagle Flat, the Texas Lineament coincides with the boundary between the Diablo Plateau and the Chihuahua Trough. Structurally, this is a low area underlain by thick deposits of mostly Cretaceous age. Major geologic units and their water bearing characteristics are detailed in Table 1.

\section{$\underline{\text { Soils }}$}

The soils along the JTF-6 Van Horn Border Road Project consist primarily of three soil associations: 1) Redona-Verhalen-Reagan association, 2) the Musquiz-Santo Tomas-Boracho association, and 3) the Nickel-Canutio-Delnorte association within Jeff Davis County. For the most part, these three associations are deep soils and subsoils resting on beds of caliche and gravel. The texture of the soils ranges from fine sand to clay with clay loams as the predominate texture (Table 2).

These soils support a variety of vegetation depending upon annual rainfall amounts. The RedonaVerhalen-Reagan and Nickel-Canutio-Delmonte associations in the area experience an annual rainfall of 6 to 14 inches. Both have sparse amounts of desert scrub vegetation. The Musquiz-Santo TomasBoracho association maintains a moderate cover of grass instead of desert scrub vegetation because of the area's increased average rainfall, over 15 inches of rainfall annually in some places. These main soil associations within Jeff Davis County primarily support rangeland, irrigated crops, and wildlife habitat. 


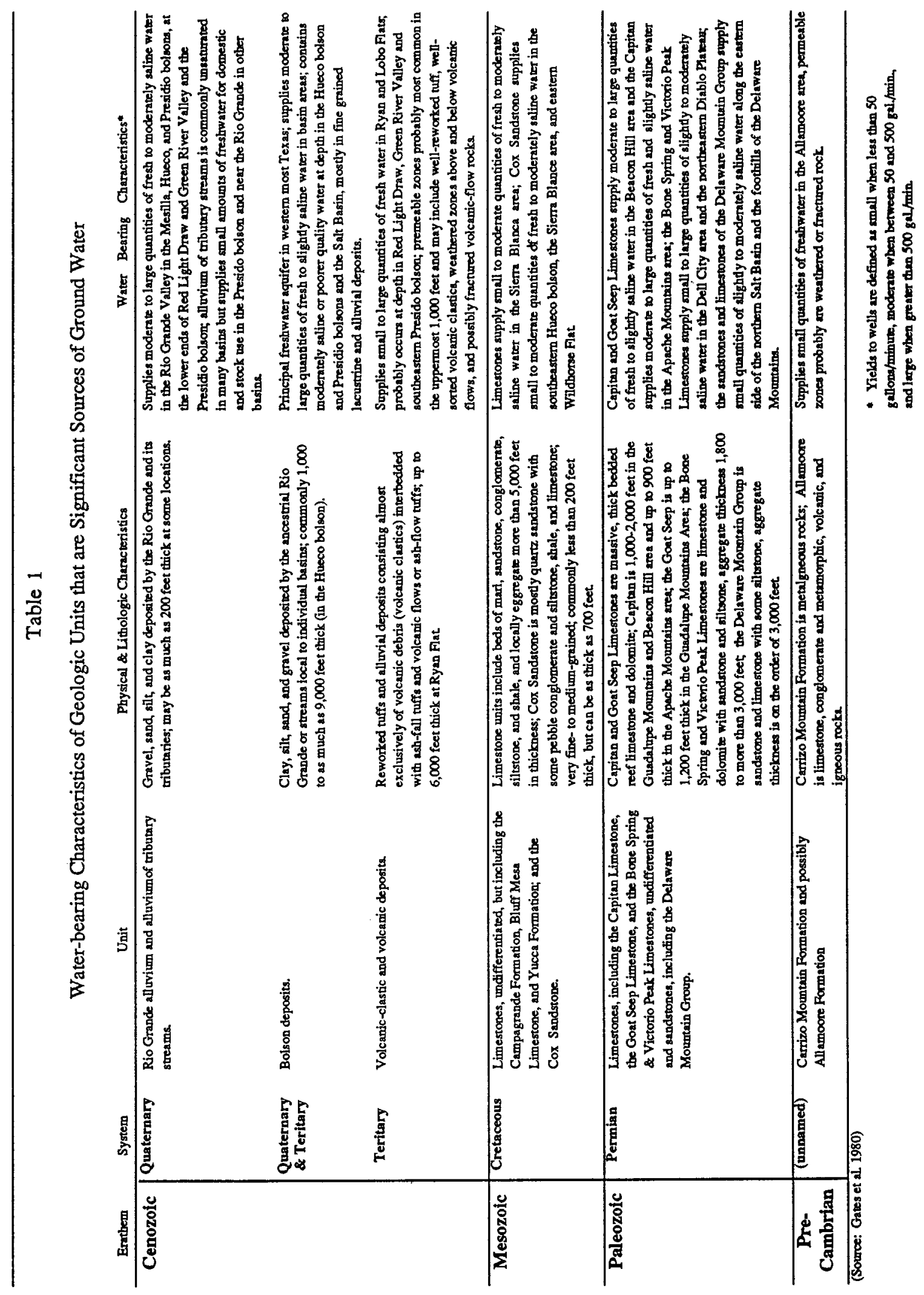


Table 2

JTF-6 Van Horn Soil Descriptions

1. REDONA-VERHALEN-REAGAN Association: Deep, nearly level to gently sloping, noncalcareous to calcareous, light colored soils on valleys and plains between the mountains. About $40 \%$ of the soils are made up of sandy loams to clays with surface layers that range from 6 to 60 inches thick. Approximately $0 \%$ of the association is made up of soils that are more gravelly, more shallow, or less clayey which occur in small drains or narrow ridges. Their main use is for rangeland and wildlife. Production potential is moderate for adapted species.

2. MUSQUIZ-SANTO TOMAS-BARACHO Association: Deep to shallow, nearly level, calcareous and noncalcareous dark colored soils on intermountain valleys. Approximately $55 \%$ of the soils in this association consist of loams and very gravelly loams to clay loams with surface layers that range in thickness from 7 to 24 inches. About $45 \%$ of the association is made up of soils that are either on flats or on old high terraces and fans next to mountains. Their main use is for rangeland wildlife. Production potential is high for adapted species.

3. NICKEL-CANUTIO-DELNORTE Association: Deep to shallow, undulating to rolling, light colored, calcareous, gravelly soils on rolling hills. About $75 \%$ of the soils in this association consist of gravelly loams to fine sands with caliche covered pebbles throughout. The surface layers range from 6 to 8 inches thick. About $25 \%$ of the association is made up of badlands and similar soils that are deeper and less gravelly. Their main use is for rangeland and wildlife. Production potential is low for adapted species.

\section{Climate}

Unless otherwise noted, the climatic conditions (long-term averages) described herein are a composite of data compiled by the U.S. Department of Commerce and National Oceanic and Atmospheric Administration (NOAA) at stations in Presidio, Van Horn (1941-1970), and Alpine, Texas (1951-1980). The climate in the area is arid sub-tropical with average total precipitation ranging from 8.61 to 14.83 inches per year. Snowfall is rare and is considered of little importance. Irrigation is required to support plant life other than desert vegetation. Winters are characterized by fair, dry weather with mild days and cool nights. Freezes occur about half the time during December and January. The lowest recorded temperatures were $-7^{\circ},-2^{\circ}$, and $4^{\circ} \mathrm{F}$ at Van Horn, Alpine, and Presidio, respectively. Upper summer daytime temperatures range from warm (under $95^{\circ} \mathrm{F}$ ) at Van Horn to over $100^{\circ} \mathrm{F}$ at Presidio. The wind, generally from the north, averages 9 miles per hour. The strongest winds occur during the spring months and are from the west southwest.

The average annual precipitation for this area is between 9 and 10 inches, of which about 75 to 80 percent occurs from May through October. Showers greater than 0.10 inches occur about once every 10 days during the summer. Very little precipitation occurs from February through April. Heavy snows ( 7 to 13 inches) have occurred at Van Horn, but are so infrequent as to be considered insignificant. The area receives abundant sunshine all year long. From 70 to 80 percent of the days throughout the year are sunny. During the fall months, the number of sunny days is reduced to about 76 percent of the days. During an average year, 193 days will be clear; 99, partly cloudy; and 73, cloudy. 
Although historic records indicate that about 2.2 days per year will exhibit heavy fog with visibility of 0.25 miles or less, no such fog was observed June through August of the recording period 1951 to 1980. The highest probability of heavy fog occurs in December and January with 0.6 and 0.7 days, respectively.

The area is arid subtropical with a mean monthly relative humidity of about 45 percent in January, from 30 to 38 percent in April, about 40 percent in July, and from 38 to 45 percent in October. Due to nighttime cooling, relative humidity increases at night with maximum values occurring in early morning near sunrise and minimum values occurring at early evening near sunset. The noon values of relative humidity are normally less than 20 percent of the morning levels and 10 percent more than the evening levels.

\section{Flora}

The JTF-6 Road Repair Project lies entirely within the Trans-Pecos mountain and basin ecological area of Texas (Gould 1969) and falls within the northern reaches of the Chihuahuan Desert (Hicks 1989:13). Of the seven major vegetative regions in the Trans-Pecos region (as defined by Schmidly 1977:8-11), three can be found in the Van Horn project area and are illustrated in Figure 2. The majority of the project area is composed of desert scrubland and grasslands with some montane woodlands present in the higher elevations.

Dominant vegetation in the project area consists primarily of three types: 1) creosotebush-lechuguilla shrub (associated with desert scrubland), 2) tobosa-black grama grassland (associated with grasslands), and 3) grey oak-pinyon pine-alligator juniper parks/woods (associated with montane woodlands). Common associates of the creosotebush-lechuguilla shrub type include mesquite, yucca, catclaw acacia, prickly pear cactus, black grama, and tarbrush (McMahan et al. 1984). Plants commonly associated with the tobosa-black grama grassland include blue grama, sideoats grama, Arizona cottontop, creosotebush, broom snakeweed, and white thorn acacia. Commonly associated plants of the grey oak-pinyon pinealligator juniper parks/woods include Gambel's oak, mountain mahogany, pine dropseed, blue grama, pinyon ricegrass, and heartleaf ground cherry.

Plants such as agave, sotol, yucca, Texas persimmon, prickly pear cactus, and ocotillo would have been economically important to the aboriginal inhabitants living in the Van Horn project area (Mallouf 1985:6-9; Hicks 1989:13). Of these plants, agave, sotol, and yucca are found in the foothills (ca. 975$1675 \mathrm{~m}$ amsl). In addition to these plants, Texas persimmon, prickly pear cactus, and ocotillo are found in the lower elevations (ca. 550-1065 m amsl).

\section{Fauna}

In the Van Horn project area there is a diversity of wildlife including a wide variety of reptiles, amphibians, fish, birds, and mammals. Generally, wildlife ranges freely between the desert scrubland and grassland vegetative regions (Schmidly 1977:12-13). Animals within the montane woodlands tend to be more restricted in their movements and venture less frequently into the desert scrublands (Schmidly 1977:12-13).

Native inhabitants within the Van Horn project area probably subsisted off a wide range of animals (ranging from large mammals to small rodents and reptiles) as evidenced by the accounts of other hunter-gatherer populations living within similar environments in south-central Texas (Ruecking 1953, 1955). Among the mammalian population, desert cottontail, black-tailed jack rabbits, Texas antelope squirrel, Mexican ground squirrel, spotted ground squirrel, desert pocket gopher, silky pocket mouse, 


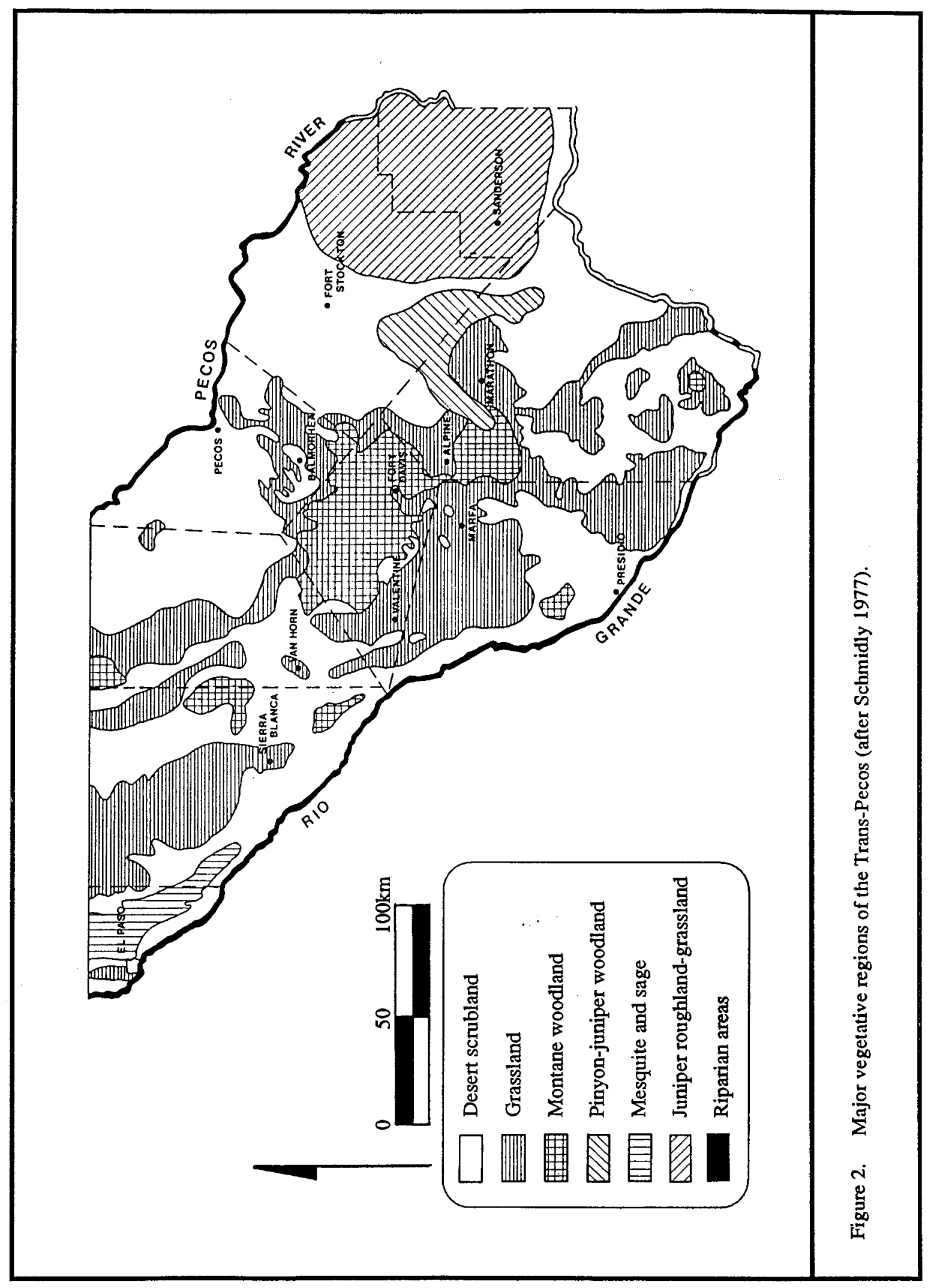


desert pocket mouse, banner-tailed kangaroo rat, coyote, ringtail collared peccary, and mule deer would have been important food resources found in the desert scrubland. Eastern cottontail, black-tailed jack rabbit, rock squirrel, black-tailed prairie dog, hispid pocket mouse, plains harvest mouse, hispid cotton rat, white-throated wood rat, porcupine, raccoon, mule deer, white-tailed deer, pronghorn, and bison would have been important food resources found in the grasslands (Schmidly 1977:19-22). In the montane woodlands, important mammalian food sources would have included eastern cottontail, rock squirrel, brush mouse, pinyon mouse, rock mouse, Mexican wood rat, Mexican vole, porcupine, black bear, white-tailed deer, and mountain (bighorn) sheep (Schmidly 1977:19-22). In addition to the important game birds such as ducks, turkeys, pigeons, and bobwhites, many species of turtles, lizards, and snakes were also probably exploited regularly by aboriginal populations living within the Van Horn project area (Geo-Marine 1989:27-42).

\section{Prehistoric and Historic Cultural Setting}

\section{$\underline{\text { Previous Investigations }}$}

The culture history of the Van Horn project area falls within the interior subregion of the Trans-Pecos area and has been recently summarized by Mallouf (1985), Hedrick (1988), and Hicks (1989). Other than the works of Kelley (1952a, 1952b, 1955, 1986), most of the archeology in the Trans-Pecos area has focused on the prehistoric past. The first archeological publications dealing with the prehistory of the Trans-Pecos area centered on the excavations of caves and rockshelters which produced finds of numerous perishable items not commonly found in other parts of Texas (Coffin 1932; Howard 1932; Smith 1932, 1933, 1934, 1938; Smith and Kelley 1933; Sayles 1935, 1941; Holden 1938, 1941; Mera 1938). Spectacular rock pictographs and petroglyphs, predominantly found in the eastern parts of the TransPecos region and along the lower Pecos River, were reported by Kirkland (1937) and Jackson (1938). Most of the more extensive archeological excavations in the Trans-Pecos area were conducted prior to 1940. Subsequent archeological investigations have been limited to a smaller scale dealing predominantly with sub-surface testing of sites (Peter n.d.:2). In the last 20 years, over 90 percent of the archeological work done in the region has been associated with cultural resource management programs (most of which have been reconnaissance in nature) involving pedestrian surveys and site testing (Peter n.d.:5).

Systematic archeological investigations in the interior subregion began in the 1930s and represent some of the earliest work done in the Trans-Pecos area (Coffin 1932; Sayles 1935; and Smith 1938). In the vicinity of Van Horn, archeological research has been going on since the late 1950s (Lehmer 1958; Hedrick 1968, 1975, 1986; Lindsay 1969; Skinner and Bousman 1973; Banks 1975; Gerald 1978; Cliff and Fifield 1980; Betancourt 1981; Foster and Kelley 1987).

\section{$\underline{\text { Prehistoric }}$}

The prehistory of the interior subregion is based on the general chronological framework of the TransPecos area (which is closely affiliated to the chronology of central Texas) and can be broken down into five temporal periods (Suhm, Krieger, and Jelks 1954; Lehmer 1958; Marmaduke 1978; Mallouf 1985; Hedrick 1988; Hicks 1989). Each temporal period is principally defined by the presence of diagnostic projectile points (Mallouf 1985:29-33), but is intended to represent more generalized developmental facies (based on subsistence practices, settlement pattern, technology, environment, etc.) within the Trans-Pecos area. It is important to note, however, that the chronological framework for this region is cursory and that very little supporting data, outside of diagnostic artifacts, is available for any one period. Beyond stratified cave or rockshelter deposits, many of the diagnostic artifacts dating to a particular period are often found in mixed association with materials from other periods. Furthermore, the radiometric dating of any one period has been tenuous at best. Of the 51 published radiocarbon 
dates recovered from archeological sites in the Trans-Pecos area, only five are prior to $2000 \mathrm{BP}$, and almost none were associated with diagnostic artifacts (Peter n.d.:4).

The five prehistoric periods are:

\author{
$\underline{\text { Temporal Period }}$ \\ Paleo-Indian \\ Early Archaic \\ Middle Archaic \\ Late Archaic \\ Late Prehistoric
}

\author{
Approximate Dates \\ $10,000-6500$ B.C. \\ 6500 - 3000 B.C. \\ 3000 - 500 B.C. \\ 500 B.C. - A.D. 1000 \\ A.D. $1000-1600$
}

\section{Paleo-Indian Period}

The Paleo-Indian period in the Trans-Pecos area is defined by the presence of basally ground, lanceolate projectile points which include Clovis, Folsom, Plainview, Golondrina, Meserve, Angostura, and Lerma types. Based on the temporal succession of these projectile points, the Paleo-Indian period can be divided on an inter-regional level into three sub-periods commonly referred to as the Llano (early), Folsom (middle), and Plano (late). The Llano sub-period is recognized by the presence of Clovis points, the Folsom by Folsom points, and the Plano (in the Trans-Pecos area) by a series of unfluted points such as Plainview, Golondrina, Meserve, Angostura, and Lerma.

On a general level, the Paleo-Indian period represents the first well-documented settlement of the New World by aboriginal peoples (of Eurasic decent) who crossed the Bearing Land Bridge during the close of the Pleistocene epoch (ca. 11,500 BP). In the west, most Paleo-Indian sites have been found in the Great Plains east of the Rocky Mountains. Although very few Paleo-Indian sites have been located in the Trans-Pecos area, the majority of the Paleo-Indian material which has been recovered in this region comes from the Rio Grande Valley (Hicks 1989:35). Sites along the Rio Grande tend to be situated on prominent terraces near sand dunes overlooking the valley (Quimby and Brooks 1967; Anderson and Carter 1981:28). In other parts of the Trans-Pecos region, Paleo-Indian occupations frequently have been found along playa shorelines (Betancourt 1981:38).

Social groups associated with the early Paleo-Indian period were probably composed of highly mobile hunter-gatherers who subsisted off of large Pleistocene herbivores supplemented with some gathered plant resources. Group size would have been restricted primarily to small bands (less than 20 individuals) who traveled on a seasonal basis over great distances in pursuit of game, or in acquisition of other kinds of food resources and raw materials. This kind of settlement pattern and subsistence strategy can be verified by the widespread inter-regional distribution of Clovis points often found hundreds of miles from the quarries from which they were produced. Much of what is known about the Clovis sub-period comes from kill sites where bones of extinct Pleistocene mega-fauna (primarily mammoths) have been found in direct association with points and other lithic tools designed for butchering.

Due to the paucity of Paleo-Indian sites in the Trans-Pecos area, almost nothing is known about Clovis occupations in this region. In the interior subregion of the Trans-Pecos area, only two isolated finds of Clovis suggest the presence of early Paleo-Indian occupations (Lindsay 1969:103; Sommer 1974:134135; Hicks 1989:36). One of these Clovis points was found near Van Horn (Lindsay 1969:103). The paucity of Clovis points may indicate that the interior subregion (as well as all of the Trans-Pecos area) was inhabited sparsely during the early part of the Paleo-Indian period and that groups merely passed through periodically from more heavily populated areas such as the Great Plains (Hicks 1989:36, 38). 
The climate during the early Paleo-Indian period was probably more moist and cooler than today, and mountain areas in the interior subregion would have been heavily forested, while the lower elevations would have been covered by pinon-juniper parklands with grassy understories (Katz 1978; Marmaduke 1978:15; McNatt 1981:121; Mallouf 1981:126, 1985:99; Hicks 1989:36, 38).

This interior subregion of the Trans-Pecos area has more frequently yielded data associated with the Folsom aspect of the Paleo-Indian period. In the vicinity of Van Horn, a number of Folsom occupations (Sommer 1974; Hedrick 1975) and a significant habitation site were recorded south of Van Horn along Wild Horse Draw (Lehmer 1958; Lindsay 1969; Betancourt 1981; Mallouf 1985:98). Unfortunately, there is not a published report on this site; nevertheless, several "dense concentrations of Folsom material," including hundreds of scrapers, knives, blades, channel flakes, gravers, and projectile points were found (Hicks 1989:36). It has been proposed that the Folsom occupation in the Van Horn area was plainsoriented (Mallouf 1981).

A number of lanceolate point finds associated with the Plano aspect of the Paleo-Indian period have also been found in the interior subregion; however, these points usually have been found in a mixed context with later occupations (Sommer 1974; Katz 1978; Marmaduke 1978; Bradford 1980; Mallouf 1985). In the vicinity of Van Horn, it appears that there was a continued presence of Paleo-Indian occupations from Folsom through Plano times (Hicks 1989:36).

Late Paleo-Indian finds (consisting of Plainview and other types of unfluted lanceolate points) in this area are frequently found along extinct playa shorelines and on creek terraces (Mallouf 1985:99; Hicks 1989:36). Based on the location of many of these occupations, it appears that late Paleo-Indian groups throughout the interior subregion were to some extent big game hunters pursuing bison and antelope in the lower elevations, and deer and bighorn sheep in the higher mountainous region (Marmaduke 1978:14, 92, 111-114, 125; Hicks 1989:36). It is suspected that during the late Paleo-Indian period and perhaps earlier, the Lobo Valley, adjacent to the Van Horn project area, served as a major north-south corridor for migratory animals traveling between the Davis and Guadalupe Mountains (Hedrick 1988:147).

During this time (ca. 8000 B.C.), the climate in the interior subregion was becoming drier and many of the forested areas were being supplanted by plants and animals affiliated with the Chihuahuan Desert regime (Mallouf 1981:133; Hedrick 1988:147). Because of the encroachment of a desert climate, it is likely that big game hunting activities were significantly curtailed by the close of the Paleo-Indian period, if not earlier (Mallouf 1985:37).

\section{Early Archaic Period}

The Early Archaic period of the Trans-Pecos area is essentially defined by the presence of projectile points which were stemmed and either corner- or side-notched. Examples are Martindale, Baker/Uvalde, Nolan, Pandale, and Bulverde points. Projectile points such as the Meserve (and possibly the Lerma), which frequently have been found in the Trans-Pecos area, clearly represent transitional forms between the Late Paleo-Indian and Early Archaic periods. Many of the Early Archaic corner- and side-notched forms also have ground bases.

As a cultural manifestation, the Early Archaic represents a period of adjustment from former PaleoIndian settlement/subsistence patterns of high mobility (partially or largely dependent on large migratory game) to a more localized hunting and gathering strategy based on a wider spectrum of plants and animals. Once in place, this kind of generalized Archaic pattern was to last for thousands of years in the Trans-Pecos area, changing very little over time (Taylor 1964:200; Shafer 1977:13). There can be little question that Early Archaic populations residing in the Trans-Pecos area were also adjusting to increasingly arid conditions which changed the landscape from a woodland/plains-like setting to a more 
desert-like environment with much less biomass (Mallouf 1985:17; Hicks 1989:69-71). Under these changing climatic conditions, forests located within the river valleys probably migrated into the higher mountain zones (Mallouf 1985:17; Hicks 1989:69-71). However, it also appears that there were still savanna-grasslands containing a mixture of woodland and desert biota in some of the lower elevations (Mallouf 1985:17).

Outside the Big Bend area, there are very few known Early Archaic occupations in the interior subregion (Katz and Lukowski 1981; Mallouf 1985:102; 1986:71; Hicks 1989:71) and virtually none have been found in the vicinity of Van Horn (Hedrick 1975). Ones that have been located in the Big Bend area are situated in the higher elevations along arroyo terraces and ridge tops (Katz 1978). These sites consist of lithic scatters, burned rock middens, and hearth fields (Andretta 1976; Marmaduke and Whitsett 1975). A few rockshelters with Early Archaic materials have also been found (Andretta 1976; Marmaduke and Whitsett 1975). Based on the paucity of archeological data, it appears that the Van Horn area was sparsely populated during Early Archaic times, and this may reflect the fact that the local environment was not conducive for long term settlement. Nevertheless, the lack of Early Archaic sites in this area may be due more to taphanomic processes than to reflecting demographic patterns.

\section{Middle Archaic Period}

The Middle Archaic period in the Trans-Pecos area is defined by the presence of large stemmed, corner-notched, and side-notched projectile points, as well as some basal notched forms. Examples are Langtry, Val Verde, Castroville, Montell, Lange, Conejo, Almagre, Williams, Shumla, and Marcos points.

The Middle Archaic period in the Trans-Pecos area represents a continuation of the general Archaic lifestyle of broad-based hunting and gathering. During this time, climatic conditions in the area became increasingly drier and warmer with some intervening wet spells (Mallouf 1981:128-131). Rockshelters in the eastern subregion and along the lower Pecos River to the east have yielded a wealth of information about the lifeways of Middle Archaic people, including a host of perishable remains such as basketry, matting, netting, cordage, sandals, worked wood, etc. In these areas, the Middle Archaic was flourishing with marked population increases relative to the earlier periods (Mallouf 1985:115; Hicks 1989:72). Indeed, the increase in rockshelter occupations (which was the preferred type of habitation site) from the Early to Middle Archaic period in the Trans-Pecos region is dramatic (Mallouf 1985:115).

Other than in the southern portions of the interior subregion, Middle Archaic settlements continued to be rare with perhaps a slight increase in their numbers subsequent to the Early Archaic period (Hicks 1989:71-72). Sites in the Big Bend area consist of open-air lithic scatters, burned rock middens, hearth fields, and some rockshelters (Bousman and Rohrt 1974:223). From these particular sites, it appears that there was a heavier reliance on plant foods (Mallouf 1985:115). Furthermore, the internal patterning of these sites appears to be very consistent. This may reflect a highly integrated level of organization which, in turn, might indicate a higher degree of territoriality among local groups (Mallouf 1985:115). Like the Early Archaic period, settlements during the Middle Archaic tend to be situated in the higher elevations along ridge crests and benches, and high stream terraces (Hicks 1989:71). In the vicinity of Van Horn, no Middle Archaic sites have been found (Katz and Lukowski 1981), and this may indicate a continued underdevelopment of the area. However, to the north of Van Horn in the Salt Basin area, a significant number of Middle Archaic occupations recently have been found (Peter n.d.:7).

\section{Late Archaic Period}

The Late Archaic period in the Trans-Pecos area is defined by the presence of smaller, side- and cornernotched points, as well as some bifurcated forms. Common types include Figeroa, Ellis, Darl, Edgewood, Frio, Paisano, Palmillas, and Ensor points. 
Climatic conditions in the Trans-Pecos area during the Late Archaic period appear to have been more moist in the beginning with a pronounced drying trend occurring towards the end (Peter n.d.:7-8). These changing climatic conditions may have produced a more varied adaptive response among groups in this area (or introduction of new populations into the region) which are reflected in the many different kinds of Late Archaic occupations, as well as in the number of different projectile point styles present throughout the region (Peter n.d.:7-8).

Overall, the Late Archaic period in the Trans-Pecos area, as in other parts of North America, represents a marked increase in population growth and intensification of food acquisition practices. For example, Late Archaic sites are found in all elevations in all kinds of physiographic settings (Hicks 1989:73), and are more heavily re-occupied, resulting in deeper midden deposits (Mallouf 1985:120-121). Ring middens and pit ovens also appear in significant numbers across the Trans-Pecos area, probably reflecting an increased utilization of plants such as prickly pear, sotol, and lechuguilla (Peter n.d.:8; Hicks 1989:73). The proportion of ground stone, especially querns, manos, and metates, also increased dramatically (Mallouf 1985:120-121; Hicks 1989:72). The introduction of cultigens, such as maize, cotton, and chili peppers into the Trans-Pecos area may have occurred during this time as well, perhaps as early as A.D. 200 to 500 (Kelley et al. 1940:27; Mallouf 1985:127). Due to increasing populations, territoriality and long distance trade relationships also became more pronounced in the Trans-Pecos region during the Late Archaic period. Indications of territoriality can be seen between the eastern interior subregion and the lower Pecos River where there are clear stylistic differences among the Late Archaic pictographs and petroglyphs which are prolific throughout this area (Mallouf 1985:125-127).

In the vicinity of Van Horn, there is a full range of Late Archaic occupations including rockshelters, lithic scatters, quarry sites, hearthfields, burned rock and ring middens, rock circles, and petroglyphs (Mallouf 1985:124-125). There can be little doubt that there was a significant increase in the number of settlements in the Van Horn area during this time period.

\section{Late Prehistoric Period}

The Late Prehistoric period in the Trans-Pecos area is defined by the presence of arrow points and ceramics, and in some areas, namely the Rio Grande, the presence of cultigens. Common arrow points associated with the Trans-Pecos Late Prehistoric include Cliffton, Toyah, Scallorn, Perdiz, Livermore, Harrell, and Fresno points. Ceramics include a wide variety of locally made and foreign wares including El Paso Brown, El Paso Polychrome, Chupadero Black on White, Jornada Brown, Three Rivers Red on Terra Cotta, Mimbres Black on White, Northern Mexican wares (polished tan, plain, Corrugated tan, and Playas Red Incised), Galisteo Black on White, Black on Red Glaze, and Middle Pecos Micaceous Brown.

The earliest and most prolific Late Prehistoric occupations in the Trans-Pecos area occurred along the Rio Grande River near El Paso and can be identilied culturally as the Jornada Mogollon (Kelley 1952a). Groups affiliated with this culture probably settled the El Paso area sometime after A.D. 200, lived in pit houses, and had formed puebloan communities with above ground structures by A.D. 1200 (Lehmer 1943; Kelley 1952a; Mallouf 1986; Hicks 1989:113-114). The Jornada Mogollon were agriculturalists and grew maize, squash, beans, and bottle gourds (Ford 1977:200; Whalen 1981:85). Farther to the south in the La Junta region near Presidio, similar puebloan communities were established along the Rio Grande and Rio Conchos Rivers by A.D. 1200 (Kelley et al. 1940:31-38; Kelley 1952b:277). It has been suspected by some that the La Junta settlements (identified as the Bravo Valley aspect) represent a southern movement of the Jornada Mogollon into the La Junta area (Shackelford 1955; Lehmer 1958). The populations of the La Junta pueblos were probably the immediate ancestors of the Patarabueye, with whom the Spanish made contact in the late sixteenth century (Lehmer 1958; Kelley 1952a, 1952b, 1955, 1986). Non-agricultural groups such as the historic Jumano (perhaps originating in the interior 
subregion) were probably in the La Junta region by Late Prehistoric times and lived periodically with the early Patarabueyes (Kelley 1952a, 1952b, 1955, 1986; Lehmer 1958; Mallouf 1985:136-138).

Ceramics and the bow and arrow probably were introduced from the Rio Grande Valley as early as A.D. 300 in the northern part of the interior subregion, and present in other parts subsequent to A.D. 900 (Mallouf 1985:129; Hicks 1989:116). To date, none of the Late Prehistoric occupations in the interior subregion appear to represent true agricultural settlements; cultigens have not been found in any convincing quantities. Nevertheless, sites with Jornada Mogollon ceramics have been found along alluvial fans, playa edges, and other level, low-lying areas which would have been conducive to simple rain-based agriculture (Mallouf 1985:129). In the Davis Mountains, some maize cobs which appear to date to the Late Prehistoric period were found in a rockshelter. This may suggest that some interior groups engaged in limited agricultural practices (Smith 1938; Mallouf 1985:134).

Overall, it appears that Late Prehistoric populations in the interior subregion carried on subsistence strategies which were similar to those practiced in the Late Archaic (Hicks 1989:117). Indeed, sites seem virtually unchanged during the Late Prehistoric period except for the presence of ceramics and arrow points. On the other hand, ceremonial rock structures, stylized rock art, and purposeful inhumations are conspicuously present during this time (Hedrick 1988), suggesting that many groups living within the interior subregion were developing complex social and ritualistic systems not seen in the earlier periods. Furthermore, it is likely that hunter-gatherers from the interior were engaged in extensive contacts with agriculturalists living along the Rio Grande Valley, as reflected by the relations between the Patarabueye and Jumano during early historic times (Mallouf 1985:136-138).

In the vicinity of Van Horn, Late Prehistoric occupations are found throughout the area and there may have been a slight increase in the number of settlements after the end of the Late Archaic period. Due to the observed high frequencies of Livermore and Toyah arrow points, Hedrick also believes that the greater Van Horn area may be the core area of Kelley's (1957) Livermore focus (Hedrick 1988:149). Based on the ceramics found in the same area, it appears there were also contacts from the outside, involving the Jornada Mogollon of the Rio Grande Valley and possibly other groups from northern Mexico (Hedrick 1988:149). Since no heavy concentrations of ceramics were found anywhere in the greater Van Horn area, outside contacts made by the Jornada Mogollon or other agriculturalists probably were limited to sporadic trading forays (Hedrick 1988:149). Since there are salt flats associated with the Salt Basin just to the north of Van Horn and not more than $50 \mathrm{~km}$ from Rio Grande Valley, it is conceivable that such commodities as salt would have attracted agricultural groups such as the Jornada Mogollon to the area on a periodic basis.

\section{Historic}

The history of the interior subregion is based on the larger historic chronological framework of the Trans-Pecos area which mirrors the general history of Texas and can be broken down into five basic temporal periods. Like the prehistoric periods, the historic periods principally are defined by particular items of material culture, in addition to historical events and other lines of documentary information. Nevertheless, each historic period is intended to demarcate a particular socio-cultural facies (based primarily on the presence of certain European and North American settlements) within the Trans-Pecos area. The five temporal periods are as follows: 
Temporal Period

Spanish Exploration

Spanish Colonial

Mexican Colonial

Texas Republic \& Nineteenth Century American

Twentieth Century American

\section{Dates}

A.D. 1535 - 1659

A.D. $1659-1821$

A.D. $1821-1836$

A.D. 1836 - 1900

A.D. 1900 - present

Spanish Exploration Period

The Spanish Exploration period is represented by the presence of European explorers in the TransPecos area. The period began around 1535 when Cabeza de Vaca and others of the ill-fated Narvaez expedition passed through the area on their way to Culiacan, Mexico, on the Pacific coast. No traces of Cabeza de Vaca's travels have been found in the Trans-Pecos area; however, it likely that he and others of the expedition passed through parts of the interior subregion south of Van Horn (see routes of Cabeza de Vaca in Skeels 1972 Figure 4, in Fox 1983:55, and Pool et al. 1975:21). Existing Native Americans in the interior subregion noted by Cabeza de Vaca were nomadic hunter-gatherers possibly affiliated with the Jumano (Kelley 1952b:277-278; Mallouf 1985:136-138; Riley 1987:295-297). Following Cabeza de Vaca, the expeditions of Rodriques-Chamuscado (1581), Espejo (1582), and Onate (1598) also passed through the Trans-Pecos area. These particular expeditions started from the small colonial town of Santa Barbara in northern Mexico and followed the Rio Conchos north to the confluence of the Rio Grande and Rio Conchos called La Junta de los Rios (Pool et al. 1975:25-27). At La Junta, these early Spanish explorers noted both Patarabueyes and the Jumano living, trading, and interacting with each other along the Rio Conchos and the Rio Grande (Kelley 1952b). Unlike Cabeza de Vaca, these later explorers did not venture deep into the interior subregion, but traveled mainly along the river routes skirting the Trans-Pecos area. However, Espejo did cross overland from the upper Pecos River to the la Junta area, somewhere to the east of Van Horn on his way back to Mexico (Kelley 1952b:265; Skeels 1972:Figure 4 [in Fox 1983:55]). Onate, noted for his founding of Santa Fe, traveled up river on the Rio Grande from La Junta through the El Paso area into New Mexico. Other than establishing base camps along the Rio Grande in the La Junta and El Paso areas, no permanent settlements were established by the Spanish in the Trans-Pecos area during this time.

Very little to no archeological information has been recovered from these first Spanish occupations in the Trans-Pecos area, and any traces conceivably dating to the Exploration period would more than likely be found along the Rio Grande River near La Junta or El Paso. In the interior subregion, there are no known sites dating to this period.

Spanish Colonial Period

The Spanish Colonial period in the Trans-Pecos area began with the establishment of a mission and frontier outpost near El Paso in 1659 (Jenkins and Schroeder 1974; Hicks 1989:139). As a result of the Pueblo Revolt in 1680, refugee Spanish colonists from Santa Fe and other northern Rio Grande settlements relocated to the small mission complex at El Paso (called Our Lady of Guadalupe) and established a permanent community there (Jenkins and Schroeder 1974:22). Shortly thereafter, in 1683 several missions and presidios were set up farther downriver in the La Junta area (Kelley 1952b:266). These later missions were established at the request of the aboriginal populations residing in the $\mathrm{La}$ Junta area, mainly for protection against incoming hostile Plains Indians, and also for reasons of consolidating the frontier boundaries along the northern borderlands claimed by the Royal Government. The La Junta mission settlements were intermittently occupied and abandoned until 1732 when they were permanently occupied until the end of the Spanish Colonial period (Kelley 1952b:266-270; Tyler 1975:26). 
During this time, Apaches and Comanches entered the Trans-Pecos area from the territory of New Mexico and carried on adversarial relationships with the Spanish colonists and Native American mission neophytes. These activities consisted of raids and counterattacks which took place chiefly along the Rio Grande Valley. As a result of the Apache and Comanche raiding, more missions and presidios were established throughout the Rio Grande in the Trans-Pecos area (Tyler 1975:31-33). By the last quarter of the eighteenth century, many mounted Native Americans from the plains were using the Trans-Pecos area extensively as a place of refuge and raiding, and as a result, military expeditions such as those carried out by Ugalde in 1787 organized to repel the marauding tribes were commissioned regularly by the Spanish authorities (Hicks 1989:139). Military campaigns were carried out in the area until 1791 when a peace treaty was finally agreed upon by all the warring parties (Tyler 1975:49). Nevertheless, the Comanche (as well as some Apaches) continued their raiding activities in the Trans-Pecos area through the first half of the nineteenth century (Hicks 1989:139).

At the turn of the eighteenth century, the Spanish colonial mission-presidio system declined considerably in Texas and other parts of the northern Spanish borderlands as a result of the disintegrating Spanish Colonial Empire (Poyo and Hinojosa 1991). By the 1790s the Rio Grande missions of the Trans-Pecos area as well as all other missions in the borderlands were essentially secularized and decoupled from centralized Spanish authority (Hinojosa 1991:74, 82). By the early 1800s, Spanish colonials and neophyte Native Americans along the Rio Grande Valley abandoned the mission system and merged into more integrated Hispanic communities centering around the old mission-presidio complexes. The inhabitants of these Rio Grande communities were engaged primarily in subsistence farming and small-scale ranching.

Other than the Mendoza-Lopez expedition which left La Junta in 1683 and crossed the interior subregion on its way to exploring central Texas, there were virtually no Spanish colonial occupations or encampments outside the Rio Grande Valley in the Trans-Pecos area. Like the Spanish Exploration period, there are no known archeological sites in the interior subregion which date to this period. However, it is conceivable that Apache or Comanche camps dating to this period may exist in some parts of the interior subregion, perhaps in the Van Horn project area.

\section{Mexican Period}

The Mexican period began with the political independence of Mexico from Spain in 1821. This period is essentially characterized by the Empresario Grant system, initiated in the closing days of the Royal Spanish Government and carried on by the newly independent Mexicans, which allowed settlement of the Texas borderlands by Anglo-Americans and immigrant Europeans. In the Trans-Pecos area, no Empresario land grants were issued, and as a result, no new settlements were added along the Rio Grande Valley or in other parts of the interior. For the most part, lives of the local inhabitants along the Rio Grande remained essentially the same as during colonial times. Nevertheless, Hispanic communities in this area continued to become more independent from the policies of Mexico City.

\section{Texas Republic and Nineteenth Century American Period}

This period began with the establishment of the Republic of Texas in 1836, and the subsequent annexation of Texas into the United States in 1845. During the first half of the nineteenth century, trade relationships between Texas, the United States, and Mexico increased significantly. As a result, local centers such as Santa Fe, San Antonio, and El Paso grew proportionately and there was a need to improve previous overland trade routes such as the Santa Fe Trail and the Camino Real, as well as to create new trails which could cross-connect with the older routes. By the end of the 1840s and beginning of the 1850 s, the Chihuahua Trail which connected Chihuahua City, Mexico to Indianola, Texas on the Gulf Coast was established (Tyler 1975:54-55). This trail followed the old Spanish route along the Rio Conchos to La Junta and then crossed overland to the northeast. The importance of the 
Chihuahua Trail in the Trans-Pecos area was twofold in that it 1) diverted some of the trade from the Santa Fe Trail, promoting more interaction with urban areas such as San Antonio, and 2) helped to establish new settlements (posts, forts, and towns) in the interior subregion (Hicks 1989:140). Other smaller east-west trails (Neighbors-Ford and Smith and Whiting) were also blazed through the TransPecos area from El Paso to San Antonio by 1849 (Pool et al. 1975:100). Both these trails passed near the vicinity of Van Horn, and the Neighbors-Ford Trail actually passed within the project area through the Van Horn Mountains.

With the annexation of Mexican lands by the United States after the Mexican-American War (18461848), settlement of the Trans-Pecos area by Anglo-Americans increased significantly. Fort Leaton and the town of Presidio were established in the La Junta area by 1848, and systematic mapping projects of the Trans-Pecos region were initiated in the early 1850s (Tyler 1975:77, 81, 101). From the Corps of Topographic Engineers, the naturalist-scientist William Emory made systematic observations of the environment along the Rio Grande Valley and adjacent mountain areas, and passed through the Van Horn area in 1852 (Pool, et al. 1975:104-105). Fort Davis was established in 1854 to protect a newly blazed road from hostile Native Americans, primarily Apache and Comanches. The road was originally surveyed in 1850 (Tyler 1975:101). Shortly thereafter, the U.S. Army also sent a small garrison from Fort Davis to Van Horn Wells in the northwest (Wylie 1973:4-5). Van Horn Wells was established near a natural spring which was situated just south of the modern town of Van Horn at the northeastern edge of the Van Horn Mountains. Based on an oral history from local 85-year-old Van Horn resident Evans Heans, there was a small military outpost located four to five miles "up stream in Van Horn Canyon on Soldier Springs Ranch--Diez y Ocho Camp" (Bearden:1977:2). Apparently this outpost was occupied until World War I (Bearden:1977:2). Another outpost called the "Valentine Fort" also was established somewhere in the vicinity of Van Horn (Bearden:1977:2). Many of these smaller establishments were set up by private landowners for protection against Indian attacks (Wylie 1973).

With the influx of prospectors and entrepreneurs passing through the Trans-Pecos region on their way to the California gold fields (Wylie 1973:1), more attention was focused on the interior subregion as a potential area for mining. As a result, silver mining began in the Chinati Mountains by 1860 , and other mines were established a few years later in the vicinity of Marfa (Tyler 1975:138-145).

Many of the newly established nineteenth century forts and settlements in the Trans-Pecos area suffered as a result of the Civil War due to the relocation of troops to the southeast. Fort Davis was abandoned, and as a consequence, raiding activities by the Apaches and Comanches increased significantly. Depredations by the mounted Native Americans were serious enough to force many settlers out of the area. Fort Davis was re-established several years after the end of the war and Native American hostilities subsided until 1876, when they resumed (Hicks 1989:140). Many of these latter raids were initiated by the Mescalero Apache under the leadership of Victorio (Tyler 1975:117-119; Hicks 1989:140). These raids lasted until his death in 1880 (Tyler 1975:117-119; Hicks 1989:140). It is worth noting that somewhere in the Eagle Mountains or adjacent area there is an alleged battle ground (date unknown) where a contingent of black soldiers fought some Indians (Wylie 1973:11). Apparently some of the blacks were killed and buried on the site (Wylie 1973:11).

Based on the oral history of Evans Heans, who moved to Van Horn in 1903, Indians camped "up and down" an unnamed river, perhaps Wild Horse Draw, where they "used to build a big fire, then take the rocks out and lay their venison or whatever on those hot rocks to cook it" (Bearden 1977:2). Heans was asked if this was the same way that the Native Americans (not named) cooked plants. He said no, "to cook Sotol they dug a well-like arrangement and put a fire in the well, the[n] put the plants in and cover[ed] them over until cooked" (Bearden 1977:2). According to Heans, the traces of these Native American encampments at one time could have been found along the edges of the river, but are scarce today because the sites have "been picked over" (Bearden 1977:1-2). 
Significant increases in settlement of the Trans-Pecos area, especially in the interior subregion, began to re-occur after the end of Indian hostilities and the arrival of the railroads in the early 1880s (Hicks 1989:140). The Southern Pacific Railroad linked El Paso with Sierra Blanca, which in turn fed to the interior settlements of Pecos and Marfa (Pool et al. 1975:164). Van Horn was established as a railroad water depot in 1881 (Peter nd.:12). Nine years earlier Presidio County had been established and Jeff Davis County was later founded in 1887 . As a result of the railroads, cattle ranching became a leading industry in the interior subregion (Hicks 1989:140). Approximately 90 percent of the cattle ranches in Presidio County were established between 1880 and 1890 (Peter nd. 12). With the discovery of mercury in 1894, mining also increased significantly around the Big Bend area and other parts of the interior subregion (Tyler 1975:138-145). During this period, copper, lead, iron, silver, tin, manganese, sulphur, fluorite, lead, marble, and salt were mined in large quantities around the Van Horn area (Peter n.d.:13).

The implementation of irrigation systems coupled with the cultivation of cotton (ca. 1870s), the use of barbed wire (ca. 1880s), and the introduction and subsequent breading of Hereford cattle (ca. 1885) were other late nineteenth century innovations which increased settlement in the interior subregion and were to have a lasting effect on the overall economy (Peter nd. 12).

\section{Twentieth Century American Period}

The twentieth century American period represents the modern era. In the Trans-Pecos area, cattle ranching and mining continued to prosper and settlements in the interior subregion increased in size and number. In the early twentieth century, Camp Holland was built for troops protecting the border from Poncho Villa. In the Big Bend area, candelilla wax factories were established in 1911 and "continue[d] to be a major industry on both sides of the border" (Hicks 1989:140). Culberson County was established in 1912 and Van Horn became the county seat. Hudspeth County was established five years later in 1917. During the 1900s, the town of Van Horn became a local center of commerce, agriculture, and mining (Wylie 1973).

Nevertheless, the interior subregion as a whole remained sparsely populated with a scattering of small communities and isolated ranches (Hicks 1989:140). Due to the basin and range topography and low population density, this area sustained its old reputation as a place of refuge and was used extensively between 1912 and 1920 by Pancho Villa and other Mexican revolutionaries as a staging ground for raids along the border (Hicks 1989:140). Based on the oral history of Evans Heans, there was a raid (called the Heville Raid) by Mexican revolutionaries somewhere in the Van Horn area (Bearden 1977:4). As a consequence, the U.S. Government sent troops into the general area and more than 100,000 National Guards were stationed along the border zone in 1916. According to Heans, a town called Pilares (located on the border south of Van Horn?) was burned "on both sides of the river" by soldiers (U.S.?) where "a lot of people were killed" (Bearden 1977:4). The burning of Pilares occurred sometime after 1918 (Bearden 1977:4).

By the early 1920s, conditions along the border became more stabilized (Tyler 1975:157-187) and the interior subregion of the Trans-Pecos area took on its modern character of small western mining and ranching towns with large cattle ranches occupying the otherwise vacant basin and range country. Today, much of the interior subregion gets its revenue from tourism, and Van Horn, since the late 1950s, has been a stopping point for tourists traveling through the area (Wylie 1973). 



\section{CHAPTER 3}

\section{RESEARCH OBJECTIVES \\ AND METHODS}

The present work was undertaken with two primary management goals in mind:

1. to locate and flag for avoidance the cultural resources occurring within the impact area of the road repair project, and,

2. to monitor the road repair work while in progress, insuring that none of the flagged sites, nor any new sites, were impacted by the project.

In addition, there were two secondary research goals:

3. to assess the research potential of the recorded sites along with their significance in regard to their potential for inclusion on the National Register of Historic Places (NRHP); and,

4. to make recommendations for the future treatment of the sites based on these assessments.

The first of these goals was accomplished by a pedestrian survey of the road areas to be impacted by the road repair project. The second goal was accomplished by examining (monitoring) areas just prior to being affected by the road improvement activities. The assessments of site significance are based largely on the presence or absence of a potential for buried deposits. These assessments, as well as recommendations for future action, are presented in a preliminary fashion in the next chapter on research results and are reiterated in the final recommendations chapter.

\section{Field Methodology}

The pedestrian survey of the road repair project area involved an on-the-ground inspection of the areas at systematic intervals. While surveying, the archeologists systematically paralleled the section of road to be repaired at intervals of 20 meters. Due to the high degree of ground surface visibility and shallow soils found within the survey area, shovel testing as a site location technique was of limited utility.

Once a site was located, its boundaries were established on the basis of the limits of the surficial materials, i.e., surface scatter of artifacts. Since the main purpose of the survey was to locate and flag sites for avoidance, shovel testing was not used as a technique to determine site area. Rough counts of surface artifacts were made and all temporally diagnostic artifacts observed on the surface were drawn, photographed, and left in place. A site form noting locational information, vegetation cover, contextual integrity, estimated temporal period, and artifactual materials was completed for each site. A scaled pace-and-compass map also was prepared for each site on graph paper. A complete photographic record, including both color and black-and-white photographs, was kept to document cultural remains, field techniques, and the general topography and condition of the area at the time of the survey. At least two overviews were taken of each site.

Archeological monitoring involved the close inspection of areas on and off the road right-of-ways which were to be affected by earth moving operations related to the road improvement activities. The earth moving activities involved the building of spreaders and the use of mechanical equipment such as bulldozers, road graders, front end loaders, and backhoes for leveling and grading of roadbeds. Some borrowing was also done off the road right-of-way in various places. 
All areas to be impacted by these kinds of activities were carefully inspected visually for the presence of artifacts or other signs of human occupation. These areas tended to be located on inclines or in other places where the surfaces were subject to heavy deflationary processes. In all areas, there were no indications of any kind of sedimentation which would have resulted in the accumulation of buried deposits. Based on these observations, once the impacted areas were inspected and cleared of having any cultural resources, it was deemed that no more monitoring work was necessary during the actual earth moving procedures. This kind of monitoring approach was also more effective in handling the anticipated multiple road improvement activities which were slated to occur simultaneously in a number of locations throughout the project area. 


\title{
CHAPTER 4
}

\section{RESEARCH RESULTS}

\author{
Introduction
}

Thirty-one cultural resource sites were identified and recorded as a result of survey and monitoring connected with the approximately 60 miles of ranch road repair near Van Horn, Texas (Table 3; Attachment 1). Of these 31 sites, 21 are located in Culberson County, eight are in Jeff Davis County and two are in Presidio County. The 31 recorded sites reflect a prehistoric temporal designation. Two sites yielded diagnostic material suggesting dates assigned to the Archaic and Archaic/Late Prehistoric periods. The lack of temporally diagnostic material precludes the classification of the remaining 29 sites (Table 4). Descriptions of each site are presented in the following section.

\section{Archeological Sites}

\section{Site $41 \mathrm{CU} 478$}

Site 41CU478 is a low-density prehistoric lithic concentration located in Culberson County alongside Yellow Tank Road southeast of the "Y" intersection at Balsh Gate and Yellow Tank Road. The site is situated on a slope below a ridge nose and is at an elevation of about 1,256 m (4,120 ft.) amsl. Approximately 15 percent of the site has been disturbed by an existing roadway which has cut into its eastern edge. An additional 5 percent has been affected by slopewash which has eroded part of the ridge nose. The site measures $50 \mathrm{~m}$ north-south by $25 \mathrm{~m}$ east-west, covering a total of about 1,000 square meters (Figure 3). Extant vegetation on the site consists of yucca, creosote, mesquite, cactus, and grass. Soils on the site are composed of sandy silts with some gravel. Some bedrock exposures were also noted. The nearest natural water source is an unnamed intermittent stream, located approximately $110 \mathrm{~m}$ to the east, which flows in a southwesterly direction until it reaches the Green River, $4 \mathrm{~km}$ away.

The site of site $41 C U 478$ was defined by surface observations. Artifacts were scattered over the entire site area on a deflated surface with no observable concentrations. These surface artifacts include less than 20 flakes, a few retouched flakes, and several cores and bifaces. No diagnostic tools were found and all artifacts were produced from chert. No features were observed.

\section{Summary}

Site 41CU478 appears to be a low-density open-air camp or lithic reduction site based on the kinds of artifacts found. No time period can be assigned due to the lack of diagnostic cultural materials. The current road work will not impact this site any further; however, it is recommended that the site be preserved if possible. This site is considered ineligible for nomination for the NRHP, and as a result, no further work is recommended at this time.

\section{$\underline{\text { Site } 41 \mathrm{CU} 479}$}

Site 41CU479 is a low-density, prehistoric lithic concentration located in Culberson County alongside Balsh Gate Road and west of Yellow Tank Road just east of a two track road. The site is situated on a low ridge top (some bedrock outcrops on the ridge slope) at an elevation of about 1,244 $\mathrm{m}(4,080 \mathrm{ft}$.) amsl. Approximately 15 percent of the site has been disturbed by an existing roadway while another 5 percent has been affected by slopewash that has cut into the margins of the site. The site measures approximately $60 \mathrm{~m}$ northeast-southwest by $35 \mathrm{~m}$ east-west, covering a total area of about 1,650 square meters (Figure 4). Existing vegetation on the site consists of yucca, creosote, cactus, and grass. Soils are composed of sandy silts with gravel. The nearest natural water source is an unnamed intermittent 
Table 3

GMI Field Number/Texas State Site Number Correlation JTF 6 / Van Horn, Texas Sector

\begin{tabular}{|c|c|c|}
\hline GMI Field \# & State \# & Quad \\
\hline GB 1 & $41 \mathrm{CU} 478$ & Lobo SW \\
\hline GB 2 & $41 C U 479$ & " \\
\hline GB 3 & 41CU480 & $"$ \\
\hline GB 4 & $41 C U 481$ & $"$ \\
\hline GB 5 & 41CU482 & $"$ \\
\hline GB 6 & $41 C U 483$ & $"$ \\
\hline GB 7 & $41 \mathrm{CU} 484$ & $"$ \\
\hline GB 8 & $41 C U 485$ & Lobo \\
\hline GB 9 & 41PS561 & Vieja Pass \\
\hline GB 10 & 41JD140 & Ninetysix Ranch \\
\hline GB 11 & 41JD141 & $"$ \\
\hline GB 12 & 41JD142 & $"$ \\
\hline GB 13 & $41 C U 486$ & Mesquite Spring \\
\hline GB 14 & $41 \mathrm{CU} 487$ & " 1 \\
\hline GB 15 & 41PS562 & Vieja Pass \\
\hline GB 16 & 41CU488 & Lobo SW \\
\hline GB 17 & 41CU489 & $"$ \\
\hline GB 18 & $41 C U 490$ & $"$ \\
\hline GB 19 & $41 C U 491$ & $"$ \\
\hline GB 20 & $41 C U 492$ & Ninetysix Ranch \\
\hline GB 21 & $41 C U 493$ & Lobo SW \\
\hline GB 22 & $41 C U 494$ & $"$ \\
\hline GB 23 & $41 \mathrm{CU} 495$ & Ninetysix Ranch \\
\hline GB 24 & $41 C U 496$ & Van Horn \\
\hline GB 25 & $41 \mathrm{CU} 497$ & Van Horn Well \\
\hline GB 26 & $41 J D 143$ & Vieja Pass \\
\hline GB 27 & 41JD144 & \\
\hline GB 28 & $41 \mathrm{CU} 498$ & Mesquite Spring \\
\hline GB 29 & 41JD145 & " \\
\hline GB 30 & 41JD146 & $"$ \\
\hline GB 31 & 41JD147 & $"$ \\
\hline
\end{tabular}


Table 4

Utilization and Estimated Period of Occupation of Sites Recorded during the JTF-6 Van Horn Road Repair Project, 1991

Site

Estimated Period

of Occupation

Type of Site

$41 \mathrm{CU} 478$

$41 \mathrm{CU} 479$

$41 \mathrm{CU} 480$

$41 \mathrm{CU} 481$

$41 \mathrm{CU} 482$

$41 \mathrm{CU} 483$

$41 \mathrm{CU} 484$

41CU485

$41 C U 486$

41 CU487

$41 \mathrm{CU} 488$

41 CU489

$41 C U 490$

$41 \mathrm{CU} 491$

41 CU492

41 CU493

$41 C U 494$

$41 \mathrm{CU} 495$

41CU496

$41 \mathrm{CU} 497$

41 CU498

41JD140

41JD141

41JD142

41JD143

41JD144

41JD145

41JD146

41JD147

41PS561

41PS562
Unknown prehistoric

Unknown prehistoric

Unknown prehistoric

Unknown prehistoric

Unknown prehistoric

Unknown prehistoric

Unknown prehistoric

Unknown prehistoric

Unknown prehistoric

Unknown prehistoric

Archaic

Unknown prehistoric

Unknown prehistoric

Unknown prehistoric

Unknown prehistoric

Unknown prehistoric

Unknown prehistoric

Unknown prehistoric

Archaic/Late Prehistoric

Unknown prehistoric

Unknown prehistoric

Unknown prehistoric

Unknown prehistoric

Unknown prehistoric

Unknown prehistoric

Unknown prehistoric

Unknown prehistoric

Unknown prehistoric

Unknown prehistoric

Unknown prehistoric

Unknown prehistoric
Open-air camp/lithic reduction site Open-air camp/lithic reduction site Lithic procurement site

Lithic procurement site

Lithic procurement site

Lithic procurement site

Lithic procurement site

Open-air campsite

Lithic procurement site

Open-air campsite

Open-air campsite

Lithic procurement site

Lithic procurement site

Lithic procurement site

Lithic procurement/reduction site

Lithic procurement site

Lithic procurement/reduction site

Lithic procurement/reduction site

Open-air campsite/hunting camp

Lithic procurement site

Lithic procurement site

Lithic procurement site

Lithic procurement site

Lithic procurement site

Lithic procurement site

Lithic procurement/reduction site

Lithic procurement/reduction site

Lithic procurement/reduction site

Lithic procurement/reduction site

Open-air campsite

Open-air campsite 


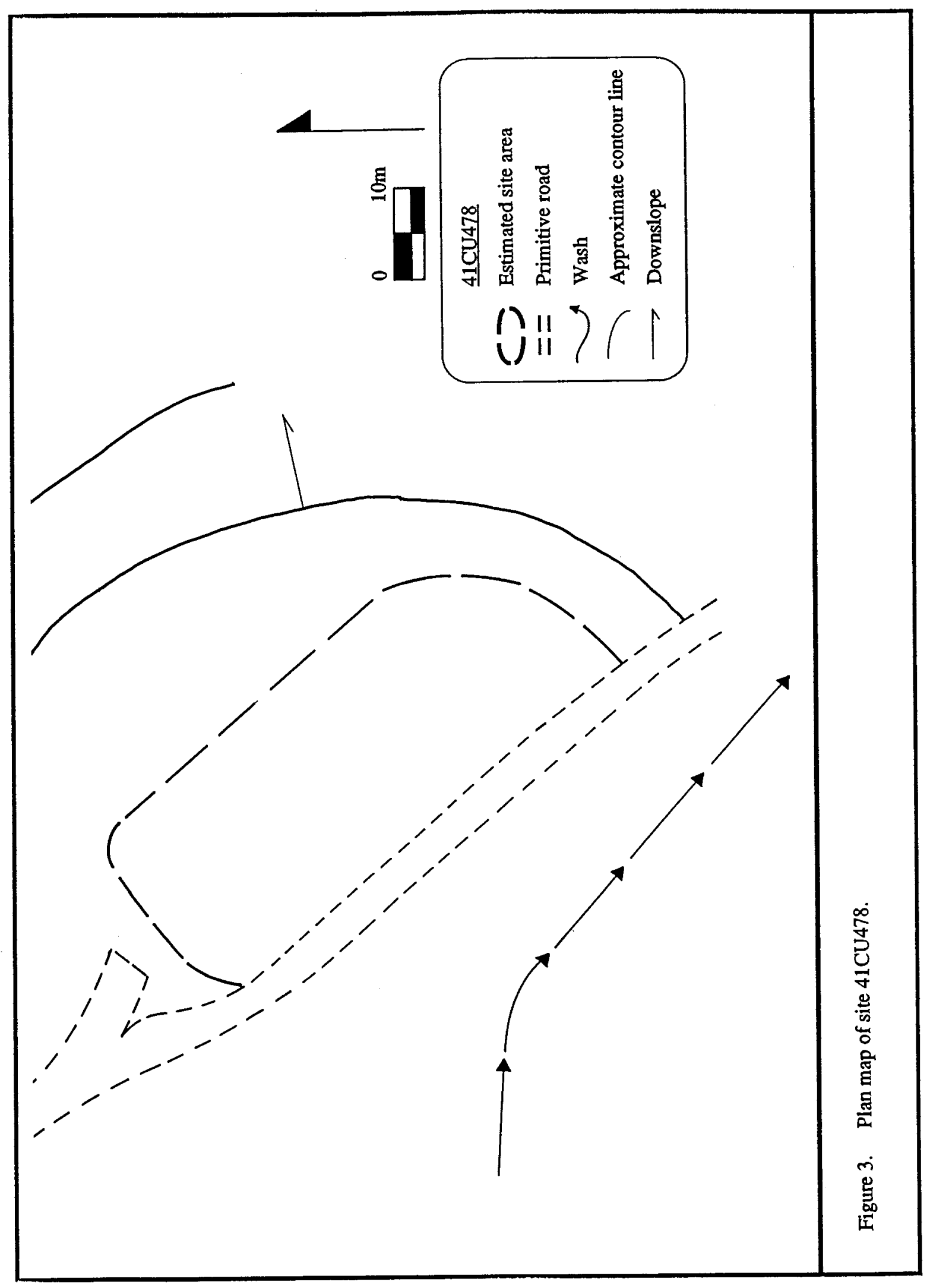




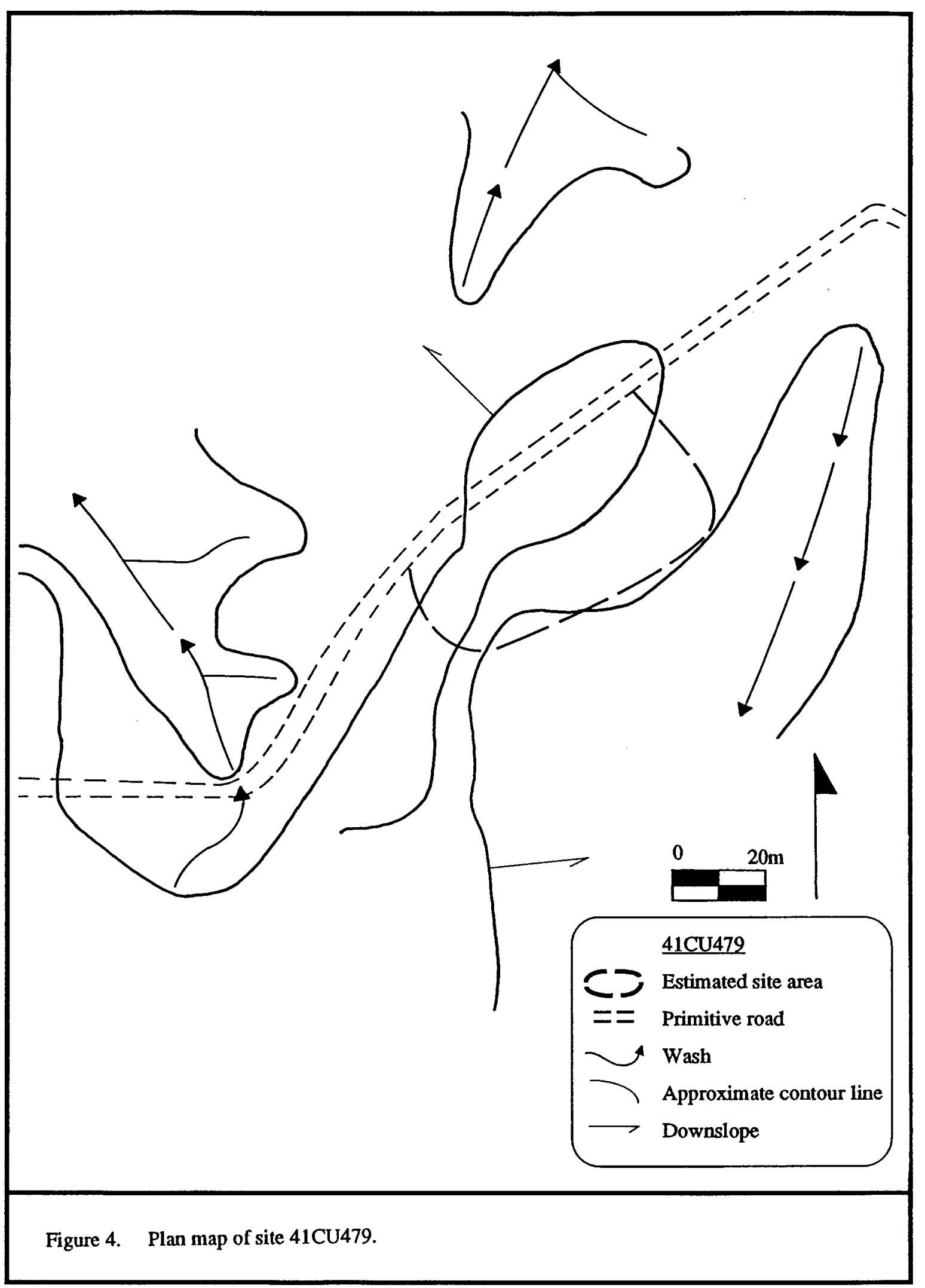


stream approximately $250 \mathrm{~m}$ to the southeast. The stream flows in a southwesterly direction for $\mathbf{3} \mathbf{~ k m}$ until it reaches the Green River.

The site was defined by surface observations. Artifacts were scattered over the entire site area on a deflated surface, with a concentration noted on the west side near the existing roadway. Surface artifacts include approximately 90 flakes, three core fragments, two biface fragments, four retouched flakes, and one endscraper. The raw materials used were chert and agate. No diagnostic tools or features were observed.

\section{Summary}

Site $41 C U 479$ appears to be a low-density, open-air camp or lithic reduction site based on the kinds of artifacts found. No time period can be assigned due to the lack of diagnostic cultural materials. The current road repair work will not impact this site any further; however, it is recommended that the site be preserved if possible. This site is considered ineligible for nomination to the NRHP, and as a result, no further work is recommended at this time.

\section{Site $41 \mathrm{CU} 480$}

Site 41 CU480 is a low-density, prehistoric lithic concentration located in Culberson County on Yellow Tank Road (east of the yellow tank) south of a small butte and quarry. The site is at an elevation of about $1,384 \mathrm{~m}(4,540 \mathrm{ft}$.) amsl and is situated on a low ridge that runs east-west. Some bedrock outcrops in several places on the site. Approximately 10 percent of the site has been disturbed by an existing graded roadway that runs through the middle of the site. An additional 5 percent has been disturbed by slopewash which has cut into the edge of the site. The site measures approximately $460 \mathrm{~m}$ east-west by $120 \mathrm{~m}$ north-south covering a total area of about 55,200 square meters (Figure 5). Existing vegetation in the vicinity consists of yucca, creosote, cactus, mesquite, and grass. Soils on the site are composed of silty sands with heavy gravel. The nearest natural water source is an unnamed intermittent stream $100 \mathrm{~m}$ to the north which flows in a southwesterly direction for $2.3 \mathrm{~km}$ until it reaches the Green River.

The site was defined by surface observations. Artifacts were scattered over the entire site area on a deflated surface and seven concentrations were noted. Surface artifacts include approximately 2,500 flakes (most being large primary flakes), 12 core fragments, six preform fragments, and 40 tested cobbles. The artifacts were knapped from chert and agate. No diagnostic tools or features were observed.

\section{Summary}

Site $41 C U 480$ is probably a lithic procurement site based on the types of artifacts found. No time period can be assigned due to the lack of diagnostic cultural materials. The current road repair work will not entail any further impact to this site; however it is recommended that the site be preserved, if possible. This site is considered ineligible for nomination to the NRHP, and as a result, no further work is recommended at this time.

\section{Site $41 \mathrm{CU} 481$}

Site 41CU481 is a low-density, prehistoric lithic concentration located on Yellow Tank Road (which runs through the site) in Culberson County. The site is slightly southwest of a small butte and quarry east of the yellow tank. Site $41 \mathrm{CU} 481$ is at an elevation of about $1,354 \mathrm{~m}(4,440 \mathrm{ft}$.) amsl and is located on a low, east-west running ridge. Bedrock outcrops in several places on the site. Approximately 10 percent of the site has been disturbed as a result of an existing graded roadway that runs through 


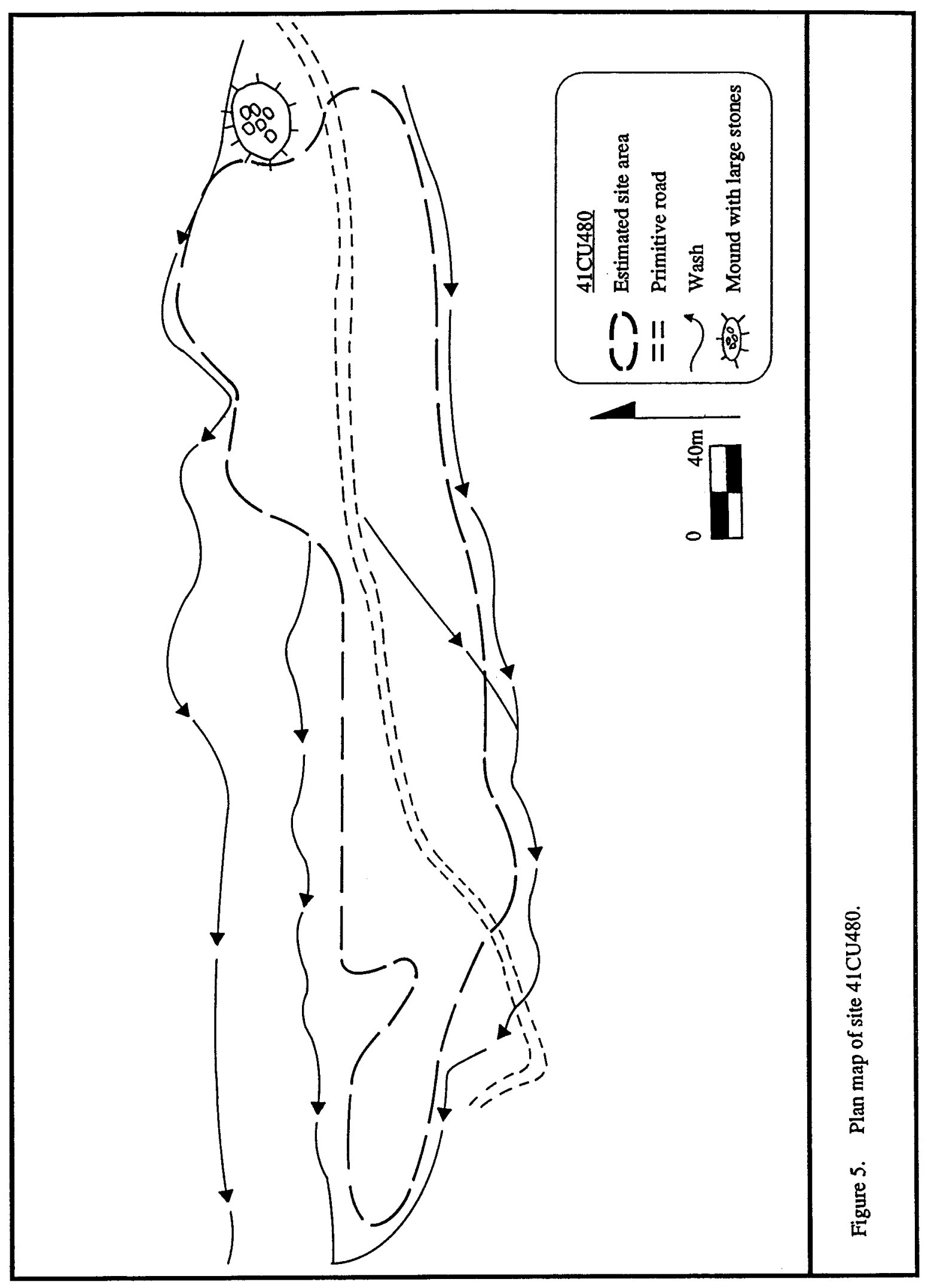


the middle of the site. Another 5 percent of the site has been affected by slopewash which has cut into the margins. The site measures approximately $360 \mathrm{~m}$ east-west by $100 \mathrm{~m}$ north-south, covering a total area of about 36,000 square meters (Figure 6). Existing vegetation on the site consists of yucca, creosote, mesquite, cactus, and grass. Soils are composed of silty sands with heavy gravel. The nearest natural water source is an unnamed intermittent stream which runs along the northern edge of the site. It flows in a southwesterly direction for $2.3 \mathrm{~km}$ until it reaches the Green River.

The site was defined by surface observations. Artifacts were scattered over the entire site area on a deflated surface and five concentrations were noted. Surface artifacts include approximately 2,000 flakes (mostly large primary flakes), eight core fragments, four preform fragments, and 30 tested cobbles. All artifacts were manufactured from chert. No diagnostic tools or features were observed.

\section{Summary}

Site 41CU481 appears to be a lithic procurement site due to the types of artifacts found. No time period can be assigned however, since no diagnostic artifacts were located. The current road repair work will not impact this site further, but it is recommended that the site be preserved, if possible. This site is considered ineligible for nomination to the NRHP, and as a result, no further work is recommended at this time.

\section{Site $41 \mathrm{CU} 482$}

Site 41CU482 is a low-density, prehistoric lithic concentration located in Culberson County east of the yellow tank along Yellow Tank Road (which runs through the site). The site is situated on an east-west running ridge at an elevation of about 1,341 $\mathrm{m}(4,400 \mathrm{ft}$.) amsl. Bedrock outcrops in several places on the site. Approximately 10 percent of the site has been disturbed by the existing graded roadway. Another 5 percent of the site has been disturbed by slopewash which has cut into the margins. The site measures approximately $480 \mathrm{~m}$ east-west by $90 \mathrm{~m}$ north-south, and covers a total area of about 38,400 square meters (Figure 7). Vegetation within the site vicinity consists of yucca, creosote, mesquite, cactus, and grass. Soils on the site are composed of silty sands with heavy gravel. The nearest natural water source is an unnamed intermittent stream approximately $100 \mathrm{~m}$ to the south, which flows in a southwesterly direction for $2.2 \mathrm{~km}$ until it reaches the Green River.

Site $41 \mathrm{CU} 482$ was identified by surface observations. Artifacts were scattered over the entire site area on a deflated surface with concentrations appearing in five areas. Surface artifacts include approximately 1,700 flakes (mostly large primary flakes), four core fragments, four preform fragments, and 25 tested cobbles. All artifacts were knapped from chert. No diagnostic tools or features were observed.

Summary

Site 41CU482 appears to be a lithic procurement site based on the types of artifacts found. No time period can be assigned due to the lack of diagnostic cultural materials. The current road repair work will not impact this site further; however, it is recommended that the site be preserved if possible. This site is considered ineligible for nomination to the NRHP, and as a result, no further work is recommended at this time.

\section{$\underline{\text { Site } 41 \mathrm{CU} 483}$}

Site $41 \mathrm{CU} 483$ is a low-density, prehistoric lithic concentration located in Culberson County east of the yellow tank on Yellow Tank Road. The site is situated on a low, east-west running ridge at an elevation of about 1,329 m (4,360 ft.) amsl. Bedrock outcrops in several areas on the site. Approximately 10 percent of the site has been disturbed by the existing graded roadway that runs through it. Another 


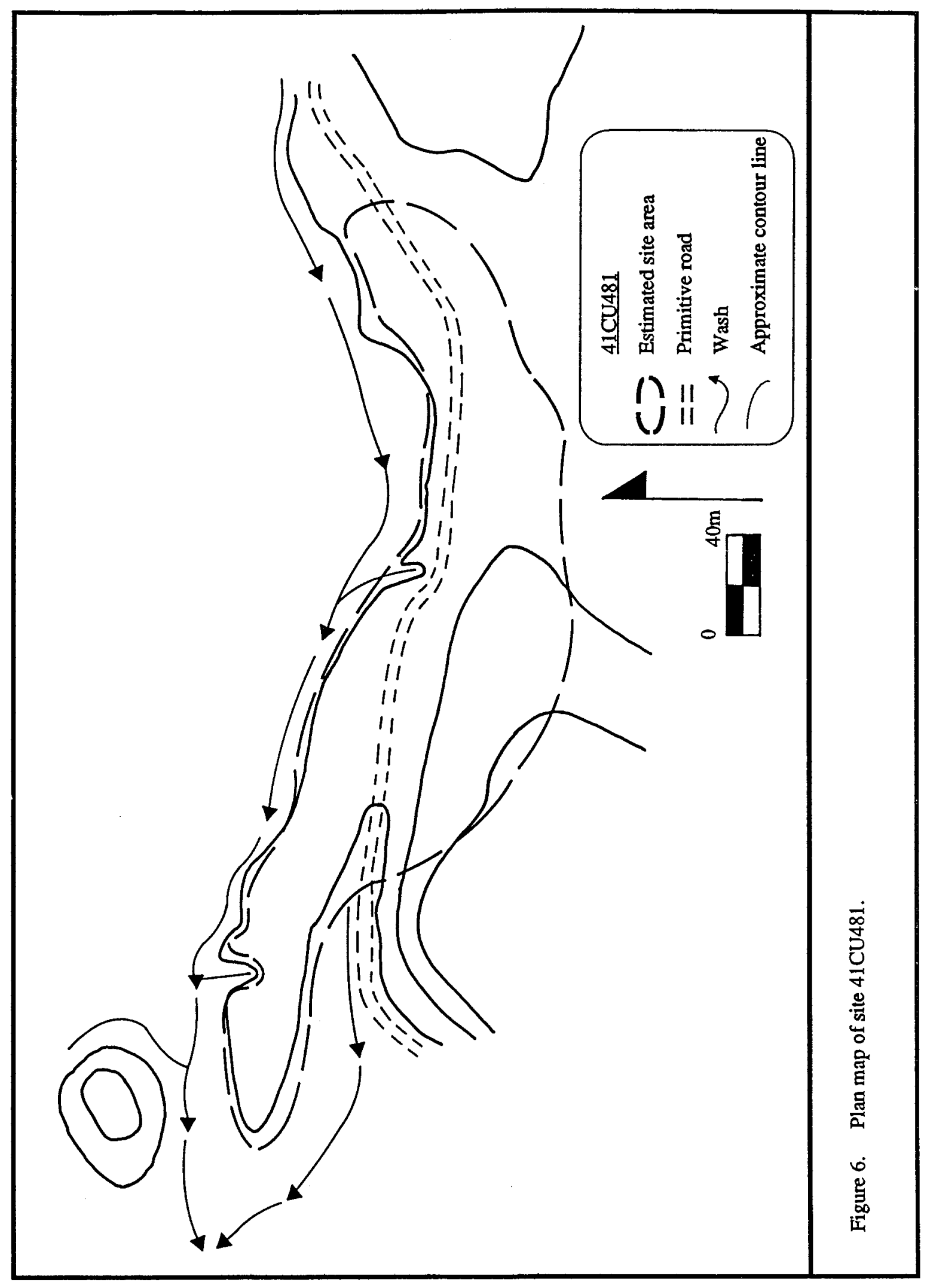




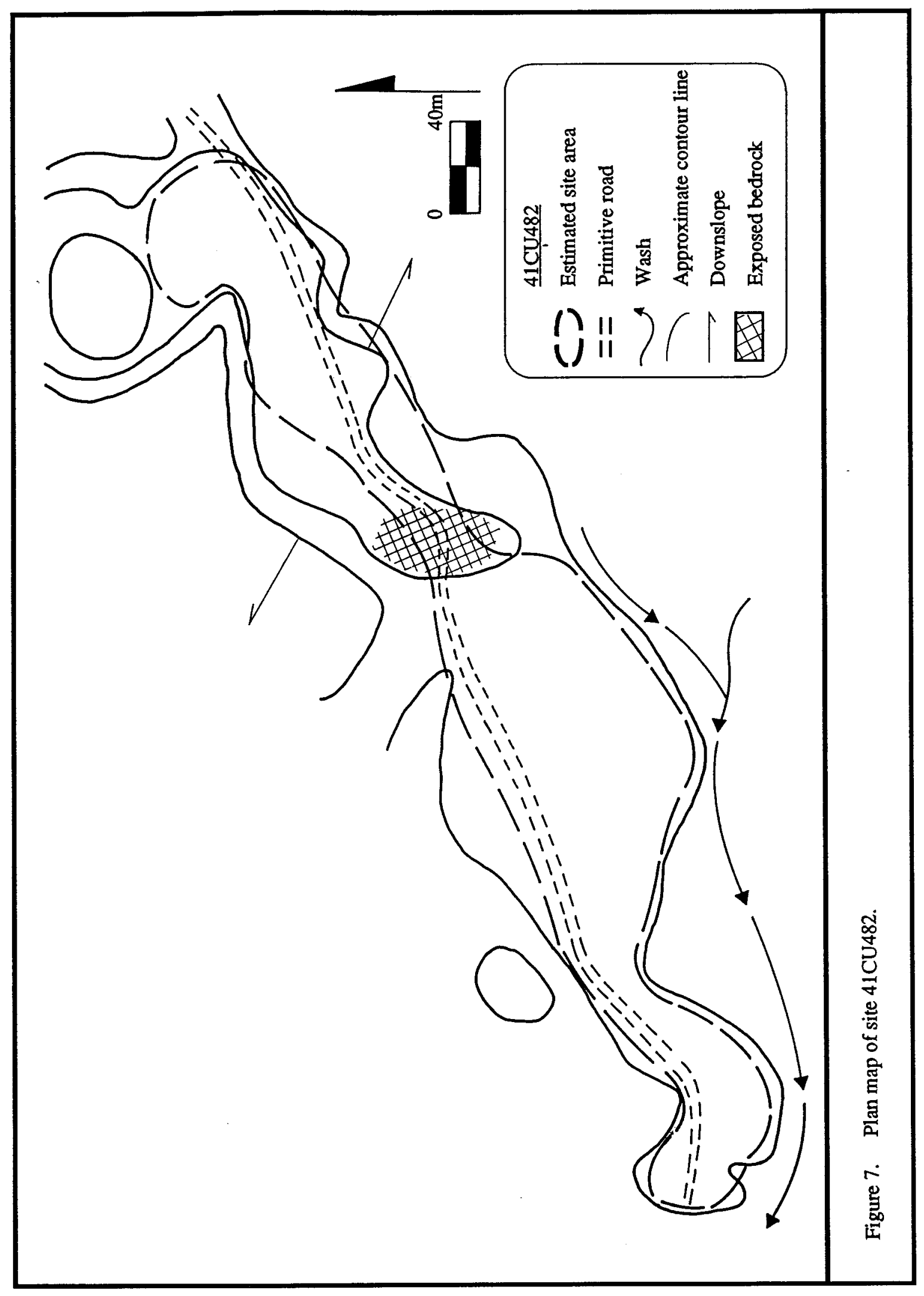


7 percent has been disturbed by slopewash which has cut into the margins of the site. The site measures approximately $15 \mathrm{~m}$ east-west by $35 \mathrm{~m}$ north-south, covering a total area of about 525 square meters (Figure 8). Vegetation within the site vicinity consists of yucca, creosote, cactus, and grass. Soils on the site are composed of sandy silts with gravel. The nearest natural water source for the site is an unnamed intermittent stream $75 \mathrm{~m}$ to the north, which flows in a southwesterly direction for $2.1 \mathrm{~km}$ until it reaches the Green River.

Site 41 CU483 was defined by surface observations. Artifacts were scattered over the entire site area on a deflated surface with no identifiable areas of concentration. Surface artifacts include approximately 45 flakes (mostly large primary flakes), two core fragments, one preform fragment, and 12 tested cobbles. All artifacts were manufactured from chert. No diagnostic artifacts or features were observed.

Summary

Site 41CU483 appears to be a lithic procurement site based on the types of artifacts found. Due to the lack of diagnostic cultural material, no time period can be assigned to the site. The current road repair work will not impact this site any further; however, it is recommended that the site be preserved if possible. This site is considered ineligible for nomination to the NRHP, and as a result, no further work is recommended at this time.

\section{$\underline{\text { Site } 41 \mathrm{CU} 484}$}

Site 41CU484 is a low-density, prehistoric lithic concentration located in Culberson County east of the yellow tank on Yellow Tank Road which runs through the site. The site is situated on a low, east-west running ridge at an elevation of about 1,323 m (4,340 ft.) amsl. Some bedrock outcrops on the site. Approximately 15 percent of the site has been disturbed by an existing graded roadway. Another 5 percent of the site has been disturbed by slopewash which has cut into its margins. The site measures approximately $75 \mathrm{~m}$ east-west by $50 \mathrm{~m}$ north-south, covering a total area of about 3,750 square meters (Figure 9). Vegetation within the site vicinity consists of yucca, creosote, mesquite, cactus, and grass. Soils on the site are composed of silty sands with gravel. The nearest natural water source for the site is an unnamed intermittent stream approximately $60 \mathrm{~m}$ to the south, which flows in a southwesterly direction for $2 \mathrm{~km}$ until it reaches the Green River.

The site was defined by surface observations. Artifacts were scattered over the entire site area on a deflated surface with no concentrations. Surface artifacts include approximately 47 flakes (mostly large primary flakes), two core fragments, one preform fragment, and 13 tested cobbles. All of the artifacts were manufactured from chert. No diagnostic cultural materials or features were found.

\section{Summary}

Site 41 CU484 appears to be a small lithic procurement site based on the types of artifacts found. Due to the lack of diagnostics, no time period can be assigned. The current road repair work will not impact this site further, but it is recommended that the site be preserved if possible. This site is considered ineligible for nomination to the NRHP, and as a result, no further work is recommended on site $41 \mathrm{CU} 484$ at this time.

\section{$\underline{\text { Site } 41 \mathrm{CU} 485}$}

Site $41 \mathrm{CU} 485$ is a moderate to medium density, prehistoric lithic concentration located in Culberson County on a high bench between two mountain ranges northeast of Elmo's Mill on Riley Ballow Road. The road runs along the southern edge of the site, and some bedrock outcrops on the northern end. The site is at an elevation of about $1,415 \mathrm{~m}(4,640 \mathrm{ft}$.) amsl. The site has been subjected to some 


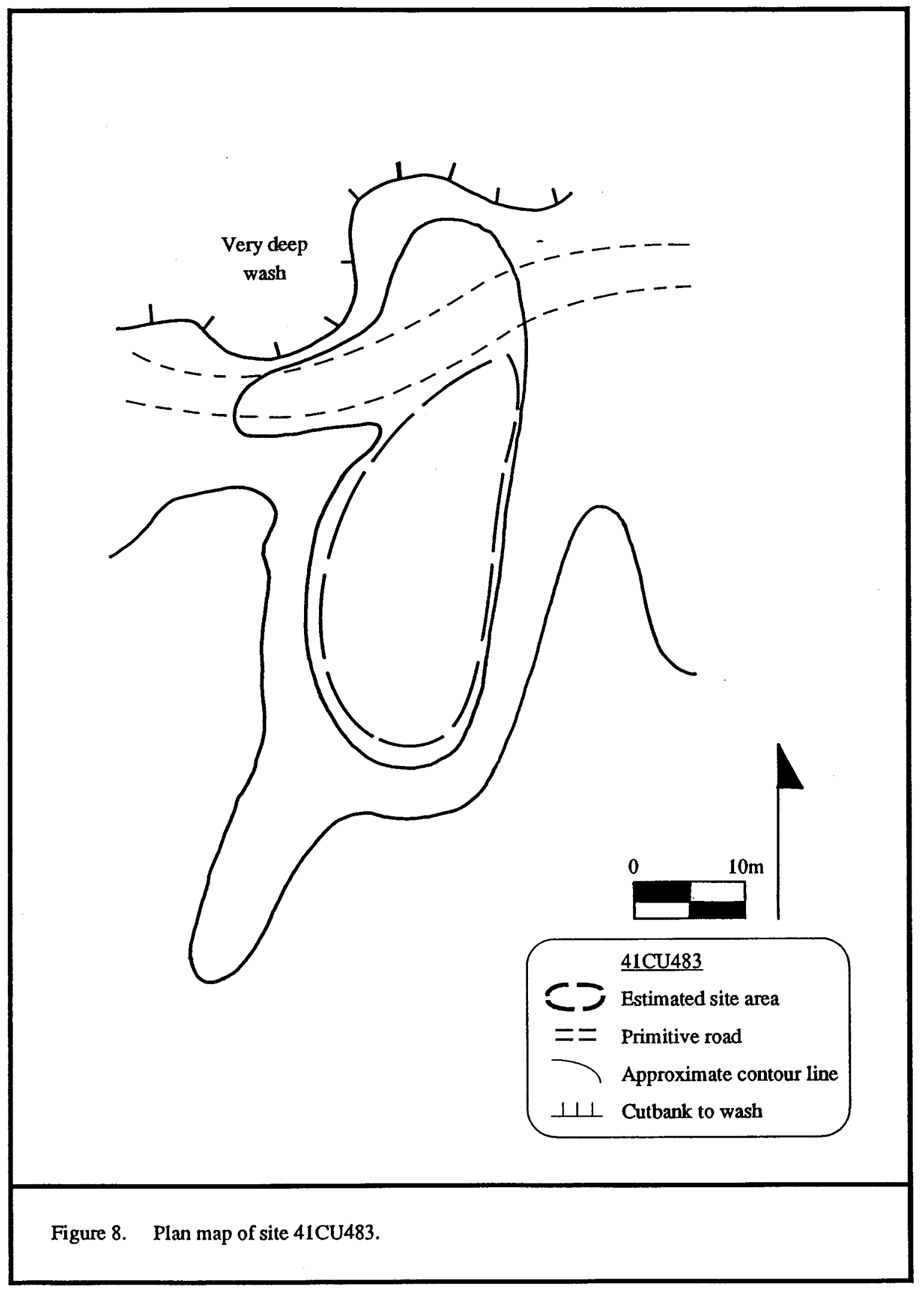




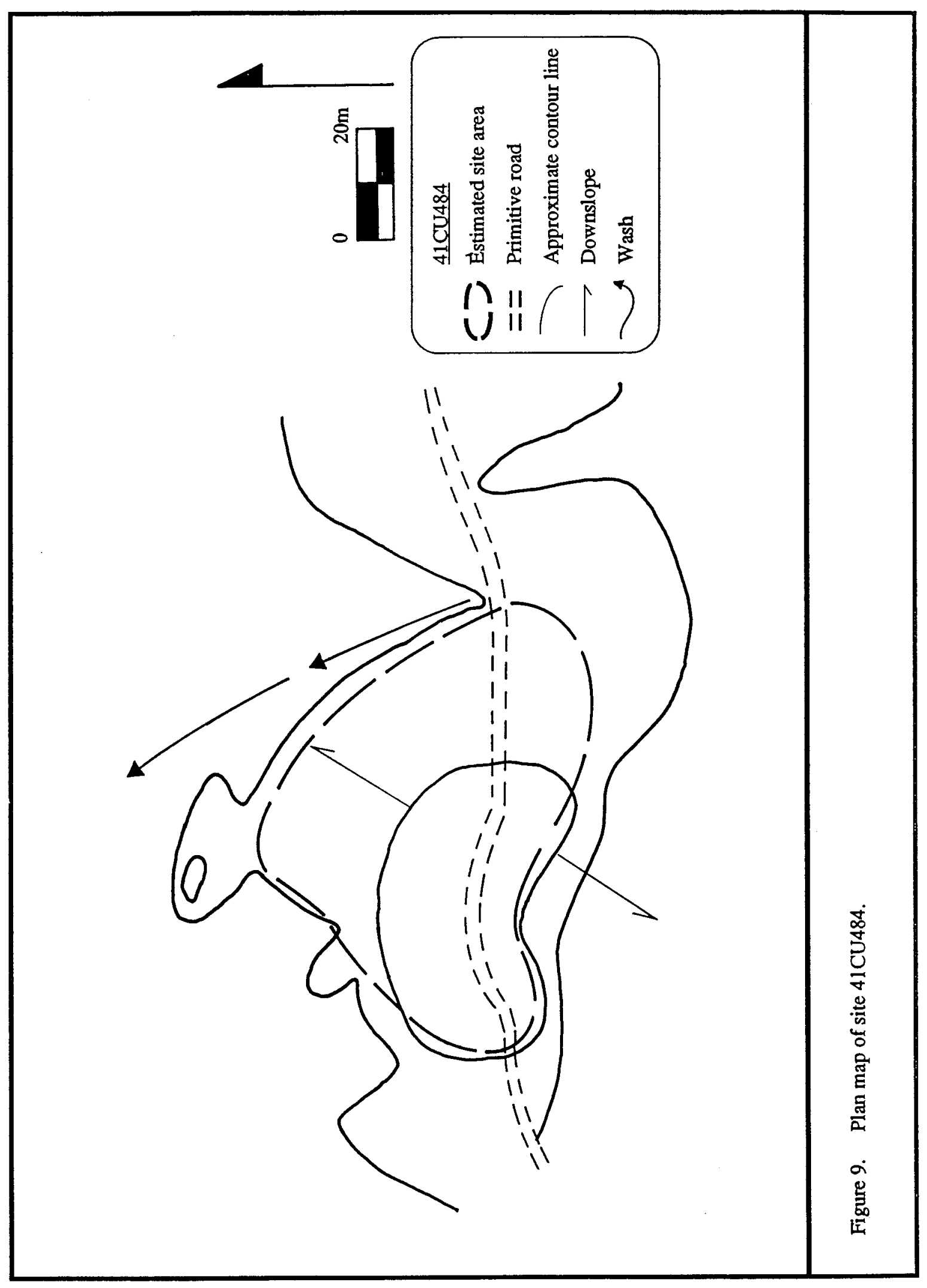


disturbance, and approximately 20 percent of the northern edge has been washed off to bedrock while an additional 10 percent of the site has been affected in the same manner elsewhere. In addition, 5 percent of the site along the southern edge has been disturbed by an existing graded roadway. A fence also runs north-south across the site area. The site measures approximately $50 \mathrm{~m}$ north-south by $120 \mathrm{~m}$ east-west, covering a total area of about 6,000 square meters (Figure 10). Vegetation on and around the site consists of yucca, sagebrush, creosote, mesquite, cactus, and grass. Soils on the site are composed of sands with gravel. The nearest natural water source for the site is an unnamed intermittent stream $70 \mathrm{~m}$ to the west which flows in a southwesterly direction for $1.7 \mathrm{~km}$ until it reaches Hammer Handle Creek.

The site was defined by surface observations. Artifacts were scattered over the entire site area on a deflated surface with a concentration noted on the southern edge of the site. Surface artifacts include approximately 200 flakes, nine biface fragments (both mid-sections and tips), and five core fragments. No diagnostics were found and all artifacts were manufactured from chert. No features were observed.

Summary

Site 41CU485 appears to be a moderate to medium density, open-air campsite based on the lack of primary flakes and the high frequency of biface fragments, secondary flakes, and pressure flakes. No time period can be assigned due to the lack of diagnostic cultural materials. The current road work will not impact this site further, but it is recommended that the site be preserved, if possible. This site is considered ineligible for nomination to the NRHP, and as a result, no further work is recommended for site $41 \mathrm{CU} 485$ at this time.

\section{Site $41 \mathrm{CU} 486$}

Site 41CU486 is a low-density, prehistoric lithic concentration located in Culberson County on a high ridge that runs north-south on a jeep trail. The Jeep trail runs from "Y" Tank Road south to White Tank Road. The jeep trail runs through the center of the site and some bedrock outcrops in the site area. The site is at an elevation of about $1,213 \mathrm{~m}(3,980 \mathrm{ft}$.) amsl. Approximately 12 percent of the site has been disturbed by the existing graded roadway that runs through the site. An additional 5 percent of the site has been disturbed by slopewash. The site measures approximately $65 \mathrm{~m}$ east-west by $40 \mathrm{~m}$ north-south, covering a total area of about 2,600 square meters (Figure 11). The vegetation within the site vicinity consists of yucca, mesquite, creosote, cactus, and grass. Soils on the site are composed of silty sands with gravel. The nearest natural water source for the site is an unnamed intermittent stream $100 \mathrm{~m}$ to the west which flows in an easterly direction for $400 \mathrm{~m}$ until it reaches Wilson Canyon.

Site 41 CU486 was defined by surface observations. Artifacts were scattered over the entire site area on a deflated surface with concentrations noted on the eastern side. Surface artifacts include approximately 65 flakes (most being large primary flakes) and eight tested cobbles. No diagnostic tools were observed and all artifacts were produced from chert. No features were found.

\section{Summary}

Site 41CU486 appears to be a small lithic procurement site based on the types of artifacts found. No time period can be assigned due to the lack of diagnostic cultural materials. The current road repair work will not impact this site further, but it is recommended that the site be preserved if possible. This site is considered ineligible for nomination to the NRHP, and as a result, no further work is recommended at this time. 


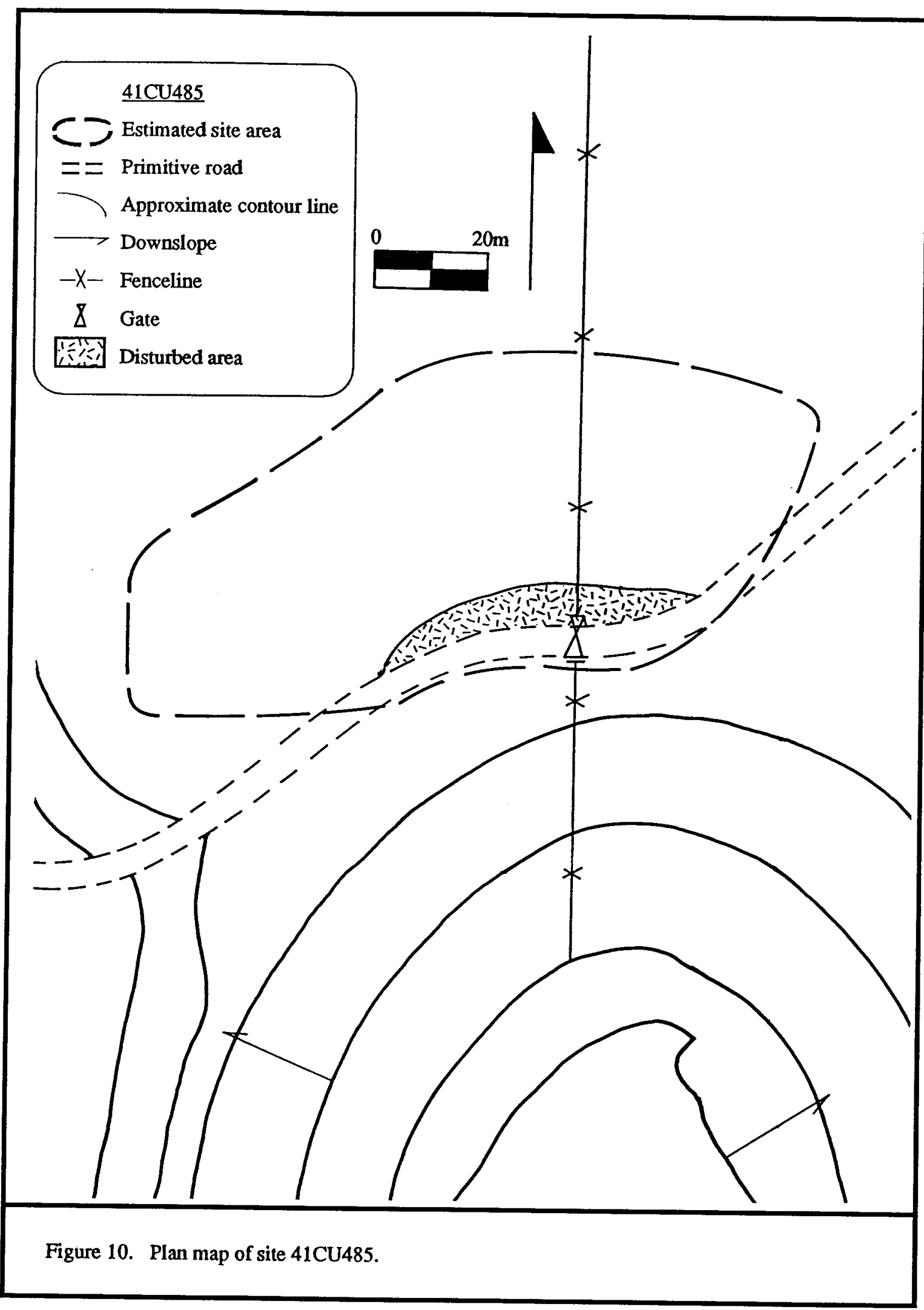




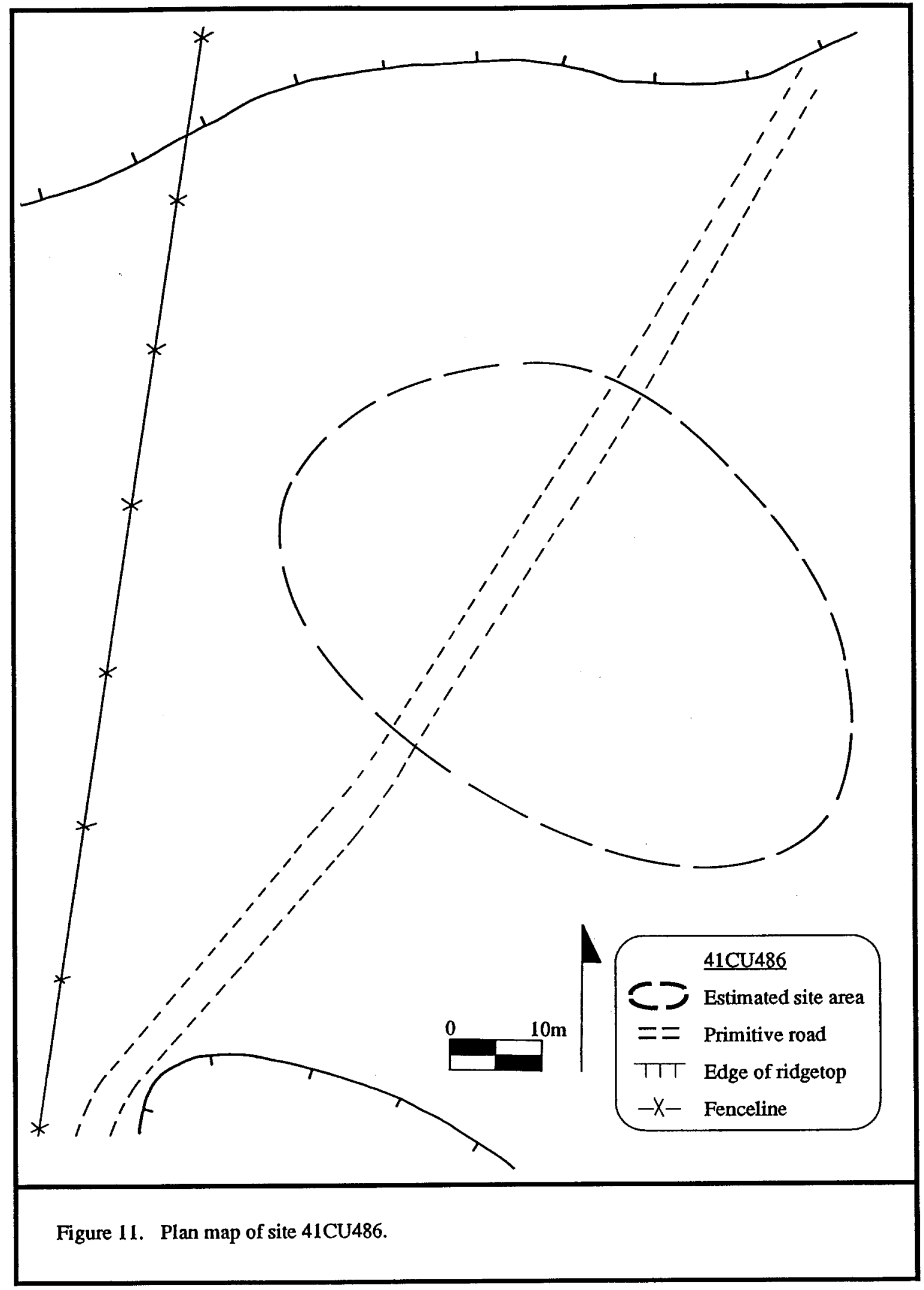




\section{Site 41CU487}

Site 41CU487 is a low-density, prehistoric lithic concentration located in Culberson County on a jeep trail that runs from "Y" Camp Road south to White Tank Road. The site is situated on a small bench south of where the jeep trail diverges from " $Y$ " Camp Road. The site is situated between two mountain ranges at an elevation of about 1,213 m (3,980 ft.) amsl. This site has been subjected to some disturbance, with approximately 5 percent of the site disturbed by slopewash and another 5 percent by previous road construction. The site measures approximately $40 \mathrm{~m}$ east-west by $35 \mathrm{~m}$ north-south, covering a total area of about 1,400 square meters (Figure 12). Vegetation on and off the site consists of yucca, mesquite, creosote, and cactus. Soils on the site are composed of silty sands with gravel. Based on observations along the road cut, some of the sediments on the site were 15 to $20 \mathrm{~cm}$ thick. The nearest marked natural water source for the site is an unnamed intermittent stream approximately $500 \mathrm{~m}$ to the south which flows in a southeasterly direction for approximately $1 \mathrm{~km}$ until it reaches Wilson Canyon.

Site 41 CU487 was defined by surface observations. Artifacts were scattered over the entire site area with a concentration noted near the center. Surface artifacts include approximately 60 flakes (some pressure flakes) and three biface fragments (one being a tip). No diagnostic tools were observed and all artifacts were made from chert. No features were found.

\section{Summary}

Site 41CU487 appears to be a small, open-air campsite based on the types of artifacts found. No time period can be assigned due to the lack of diagnostic cultural materials. The current road repair work will not impact this site; however, it is recommended that the site be preserved if possible. Eligibility for this site is unknown at present; however, no further work is recommended at this time. If this site is to be affected by future road construction activities, then testing should be implemented to see if any buried deposits exist there.

\section{Site 41CU488}

Site $41 \mathrm{CU} 488$ is a moderate to medium density, prehistoric lithic concentration located in Culberson County on a small bench overlooking an intermittent stream on Yellow Tank Road. The site is just east of the yellow tank several kilometers west of High Lonesome Mountain near where two mountain ranges

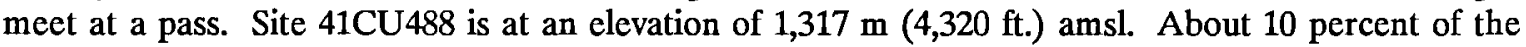
site area has been disturbed by an existing graded roadway that cuts through the eastern edge of the site, while an intermittent stream has been cutting off an additional 10 percent of the site area on the southern margin. Some bedrock is exposed across the site area. The site measures approximately $75 \mathrm{~m}$ east-west by $55 \mathrm{~m}$ north-south, covering a total area of about 3,750 square meters (Figure 13). The vegetation on the site consists of yucca, mesquite, cactus, creosote, catclaw, and grass. Soils on the site are composed of silty sands and gravel with some possible depth. The nearest natural water source for the site is an unnamed intermittent stream which runs along the southern edge of the site and flows in a southwesterly direction for $1.8 \mathrm{~km}$ until it reaches the Green River.

Site $41 \mathrm{CU} 488$ was defined by surface observations, with no shovel testing employed. Artifacts were scattered over the entire site area with a concentration noted on the southern side. Surface artifacts include approximately 300 flakes (some pressure flakes), six bifaces, and three scrapers. In addition, three projectile points from the site were observed in the collection of a local collector (Figure 14). All of these appear to dart points and all three were produced from chert. No features were observed at the site. 


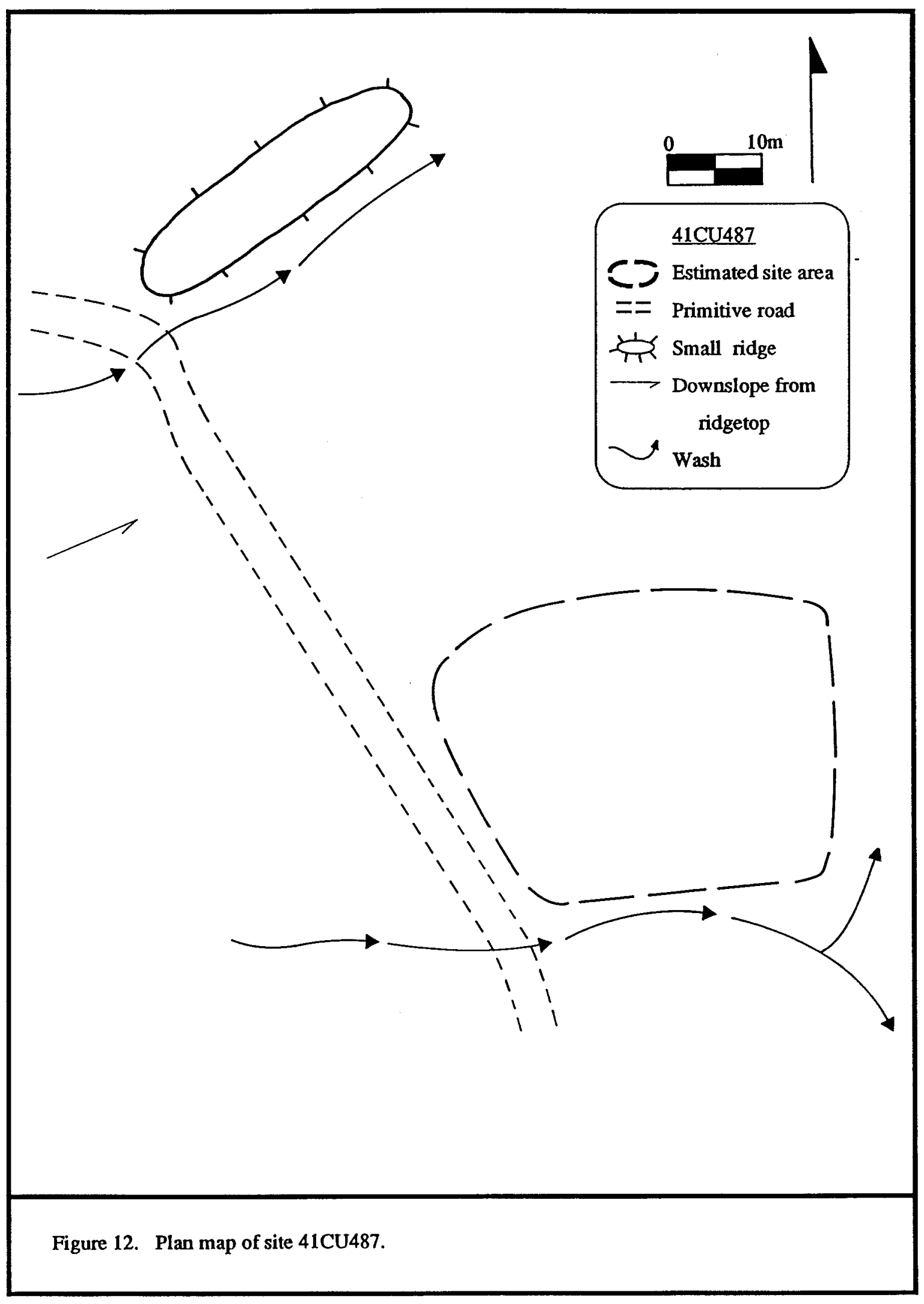




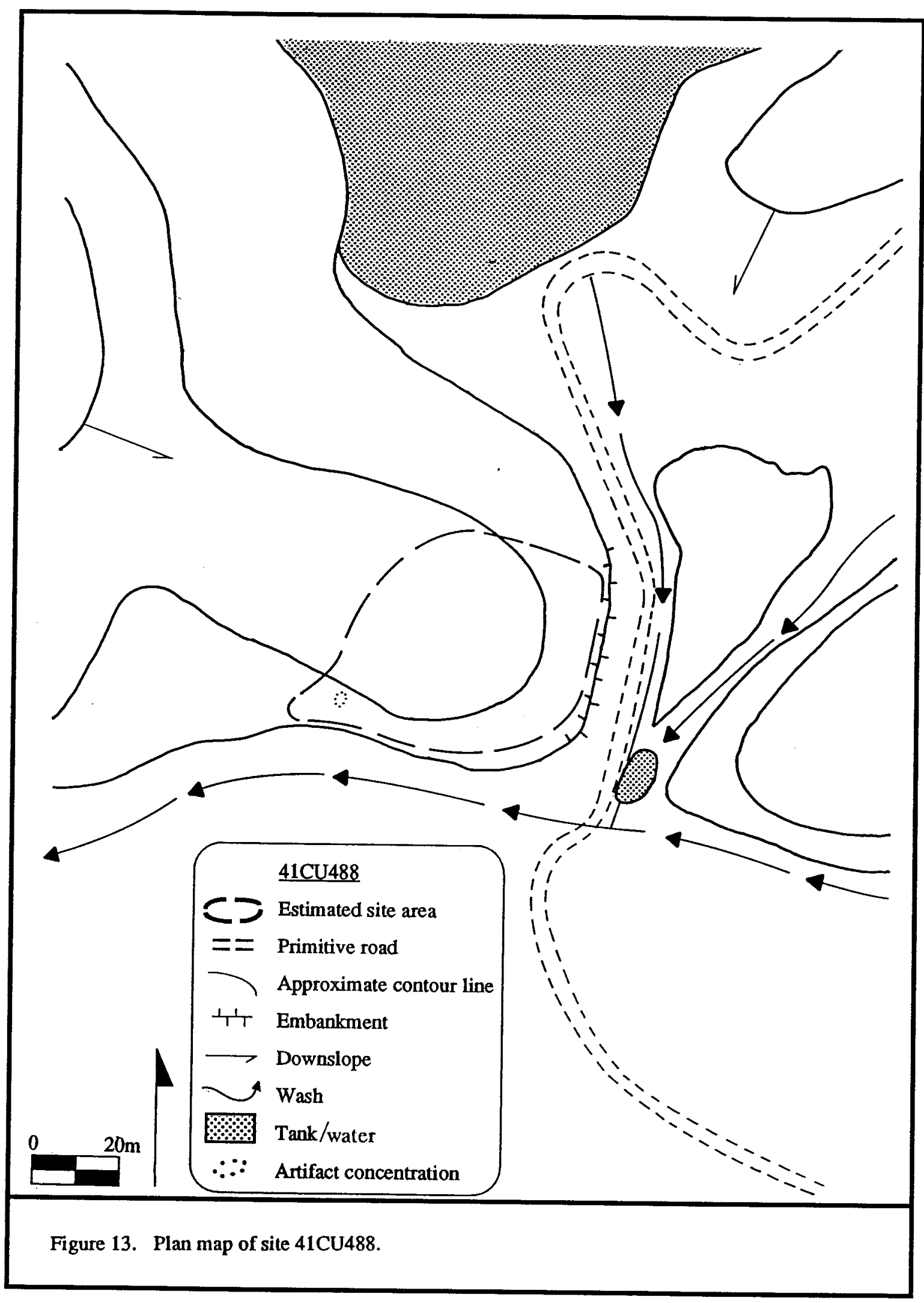




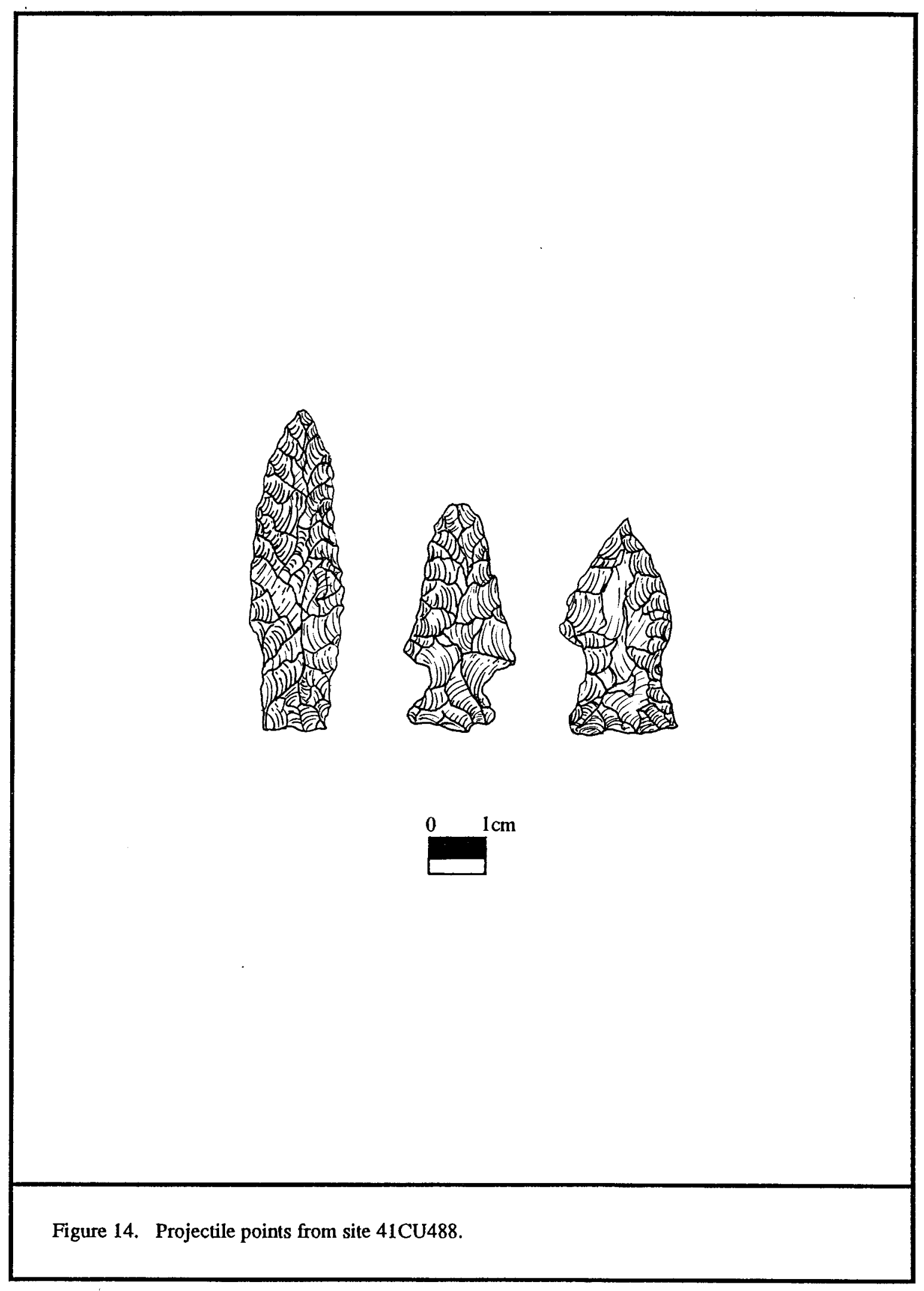


Site 41CU488 appears to be an open-air campsite based on the types of artifacts found. The site probably dates to sometime in the Archaic period, based on the three dart points collected from the surface of the site by a local collector. The current road repair work will not impact this site, but it is recommended that the site be preserved if possible. Eligibility for this site is unknown at present; however, no further work is recommended at this time. If $41 \mathrm{CU} 488$ is to be impacted by future construction activities, then testing is recommended to determine whether buried deposits or features exist.

\section{Site $41 \mathrm{CU} 489$}

Site $41 \mathrm{CU} 489$ is a moderate to medium density, prehistoric lithic concentration located in Culberson County on a small ridge nose between two unnamed intermittent streams. The site is situated just to the east of Yellow Tank Road, not far from the yellow tank, and is very close to site 41CU488. $41 \mathrm{CU} 489$ is situated in a pass between two mountain ranges at an elevation of about $1,331 \mathrm{~m}(4,365 \mathrm{ft}$.) amsl. Approximately 5 percent of the site has been disturbed by slopewash. Some bedrock outcrops on the site. The site measures approximately $90 \mathrm{~m}$ east-west by $45 \mathrm{~m}$ north-south, covering a total area of approximately 4,050 square meters (Figure 15). Vegetation within the site vicinity consists of yucca, mesquite, cactus, creosote, catclaw, and grass. Soils on the site are composed of silty sands with some gravel. The nearest natural water source for the site is an unnamed intermittent stream which runs along the western edge of the site and flows in a southwesterly direction for $1.9 \mathrm{~km}$ until it reaches the Green River.

Site $41 \mathrm{CU} 489$ was defined by surface observations. Artifacts were scattered over the entire site area on a deflated surface with no concentrations. Surface artifacts include approximately 250-300 flakes, one preform fragment, and eight tested cobbles. These artifacts were all knapped from chert. No diagnostic tools or features were found.

\section{Summary}

Site 41CU489 appears to be a lithic procurement site, based on the types of artifacts found. No time period can be assigned since no diagnostic cultural materials were located. The current road repair work will not impact this site; however, it is recommended that the site be preserved if possible. This site is considered ineligible for nomination to the NRHP, and as a result, no further work is recommended at this time.

\section{Site $41 \mathrm{CU} 490$}

Site 41CU490 is a low-density, prehistoric lithic concentration located in Culberson County on a small ridge overlooking an intermittent stream between two mountain ranges on Yellow Tank Road. The site is southeast of the yellow tank (Yellow Tank Road runs through the middle of the site) and is at an elevation of about 1,329 $\mathrm{m}(4,360 \mathrm{ft}$.) amsl. Approximately 10 percent of the site has been disturbed by the existing graded roadway that runs through the center of the site area. Another 5 percent has been disturbed by slopewash. The site measures approximately $57 \mathrm{~m}$ east-west by $30 \mathrm{~m}$ north-south, covering a total area of about 1,710 square meters (Figure 16). Vegetation on and off the site consists of yucca, creosote, mesquite, cactus, and grass. Soils on the site are composed of silty sands with gravel. Some bedrock exposures are also present. The nearest natural water source for the site is an unnamed intermittent stream, located approximately $20 \mathrm{~m}$ to the east, which flows in a southwesterly direction for $1.9 \mathrm{~km}$ until it reaches the Green River. 


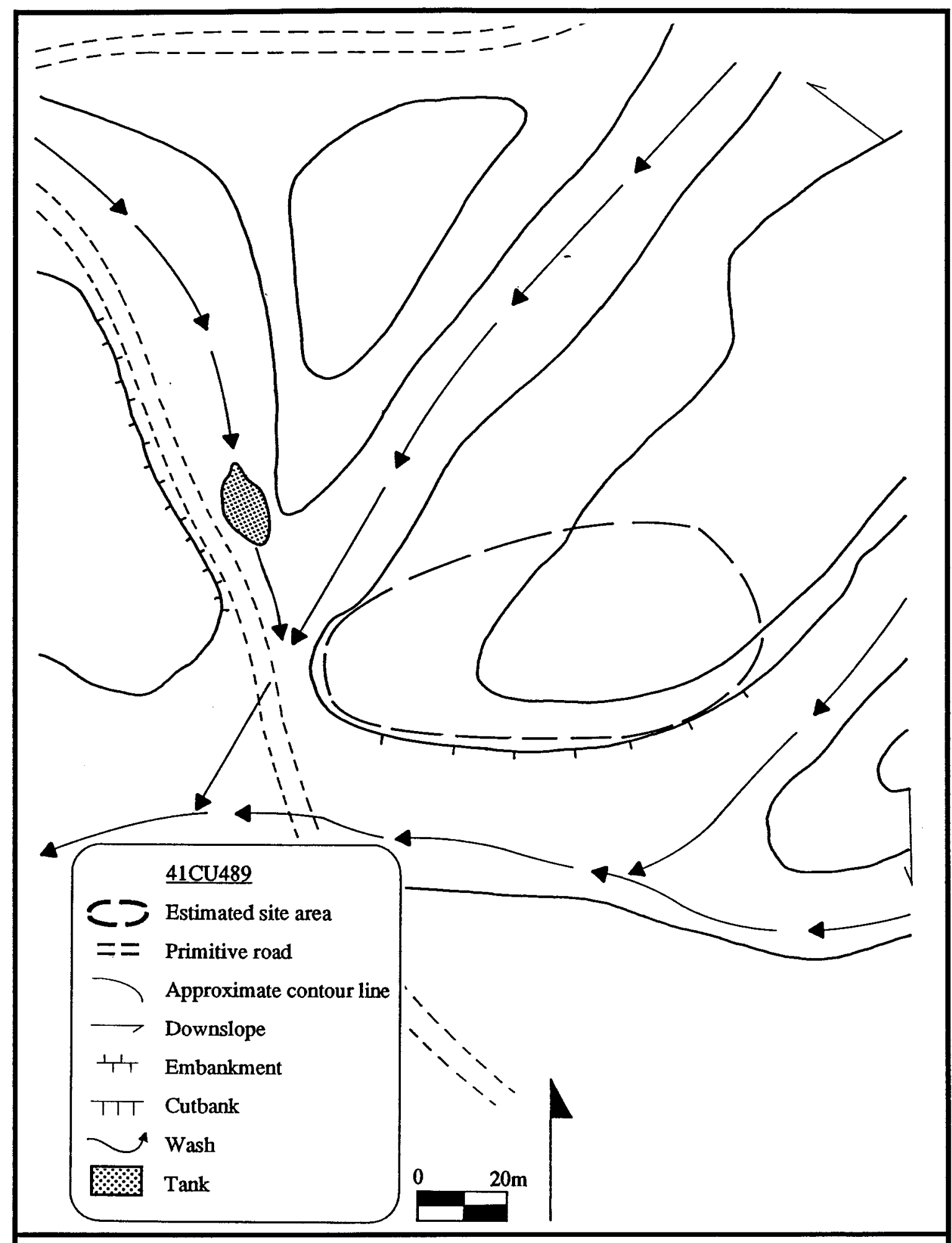

Figure 15. Plan map of site 41CU489. 


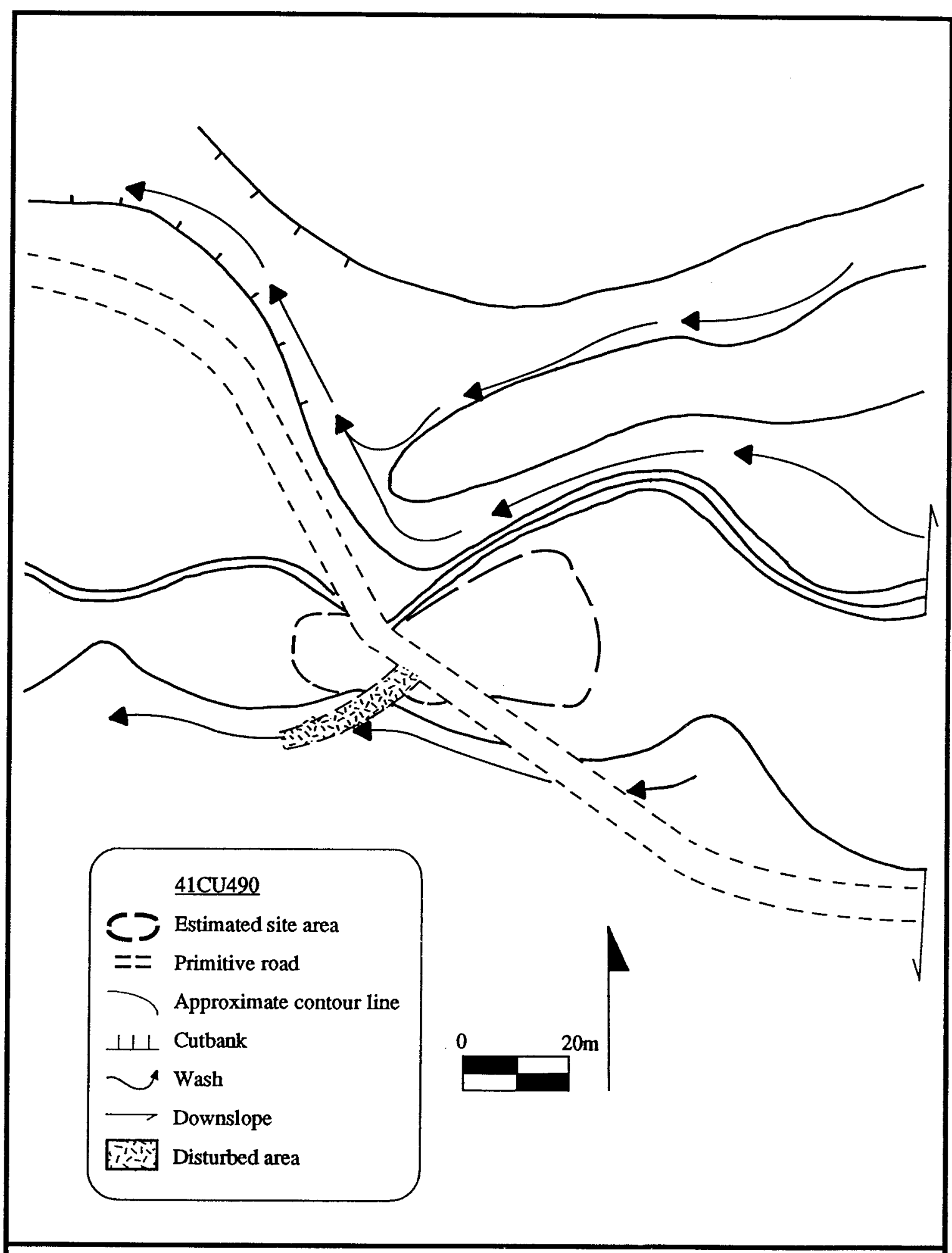

Figure 16. Plan map of site $41 \mathrm{CU} 490$. 
Site $41 \mathrm{CU} 490$ was defined by surface observations. Artifacts were scattered over the entire site area on a deflated surface with no concentrations. Surface artifacts include approximately 40 flakes, three tested cobbles, and one biface fragment. No diagnostics were observed and all artifacts were manufactured from chert. No features were found.

\section{Summary}

Site $41 \mathrm{CU} 490$ appears to be a small lithic procurement site based on the types of artifacts found. No time period can be assigned due to the lack of diagnostic cultural materials. The current road repair work will not impact this site further; however, it is recommended that the site be preserved if possible. This site is considered ineligible for nomination to the NRHP, and as a result, no further work is recommended at this time.

\section{Site $41 \mathrm{CU} 491$}

Site $41 \mathrm{CU} 491$ is a low-density, prehistoric lithic concentration located in Culberson County (southeast of the yellow tank) on a ridge nose (overlooking an unnamed intermittent stream) which is situated between two mountain ranges. The site is at an elevation of about $1,329 \mathrm{~m}(4,360 \mathrm{ft}$.) amsl and Yellow Tank Road runs through a portion of it. Approximately 15 percent of the site has been disturbed by the existing graded roadway that runs through the southwest corner. An additional 5 percent has been disturbed by slopewash. The site measures approximately $100 \mathrm{~m}$ east-west by $95 \mathrm{~m}$ north-south, covering a total area of about 9,500 square meters (Figure 17). Vegetation on and around the site consists of yucca, creosote, mesquite, cactus, and grass. Soils on the site are composed of sandy silts with gravel and some bedrock exposures are also present. The nearest natural water source for the site is an unnamed intermittent stream approximately $40 \mathrm{~m}$ to the east which flows in a southwesterly direction for $1.9 \mathrm{~km}$ until it reaches the Green River.

Site 41CU491 was defined by surface observations. Artifacts were scattered over the entire site area on a deflated surface with no concentrations. Surface artifacts include approximately 40 flakes, four tested cobbles, and three preform fragments. No diagnostic tools were found and all artifacts were manufactured from chert. No features were observed.

\section{Summary}

Site 41CU491 appears to be a small lithic procurement site based on the types of artifacts found. No time period can be assigned due to the lack of diagnostic cultural materials. The current road repair work will not impact this site further, but it is recommended that the site be preserved if possible. This site is considered ineligible for nomination to the NRHP, and as a result, no further work is recommended at this time.

\section{$\underline{\text { Site } 41 \mathrm{CU} 492}$}

Site $41 \mathrm{CU} 492$ is a low-density, prehistoric lithic concentration located in Culberson County on a terrace between two mountain ranges on "Y" Camp Road. The site is situated south-southeast of the "Y" Camp at an elevation of about $1,271 \mathrm{~m}(4,140 \mathrm{ft}$.) amsl. Approximately 5 percent of the site has been disturbed by slopewash. The site measures approximately $45 \mathrm{~m}$ east-west by $20 \mathrm{~m}$ north-south, covering a total area of about 800 square meters (Figure 18). Vegetation within the site vicinity consists of yucca, creosote, cactus, and grass. Soils on the site are composed of sandy silts with gravel. Along the road cut, sediments in some areas were $5 \mathrm{~cm}$ thick. Bedrock exposures also exist. The nearest natural water source for the site is an unnamed intermittent stream $90 \mathrm{~m}$ to the south which flows in a northwesterly direction for $1.4 \mathrm{~km}$ until it reaches Wilson Canyon. 


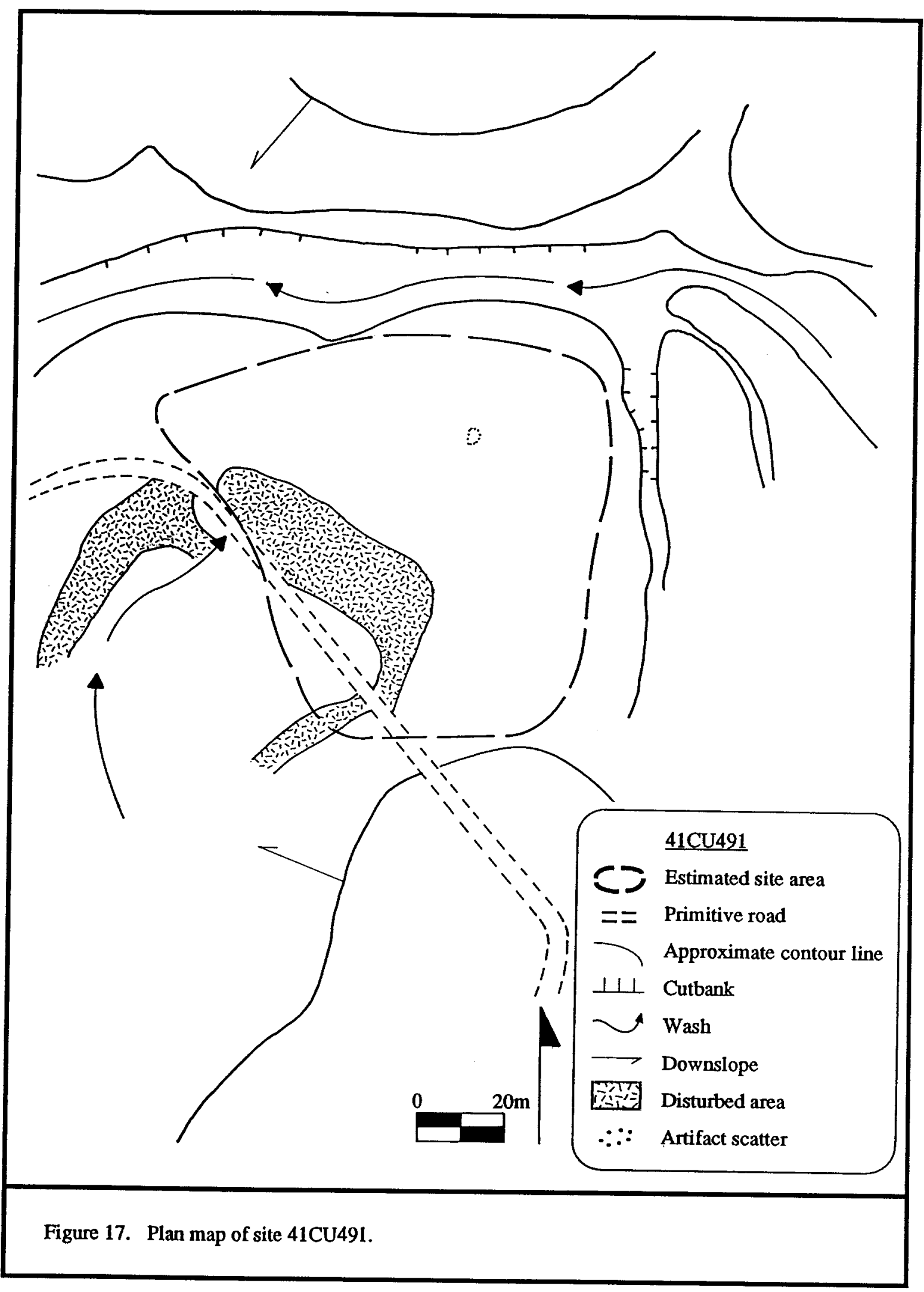




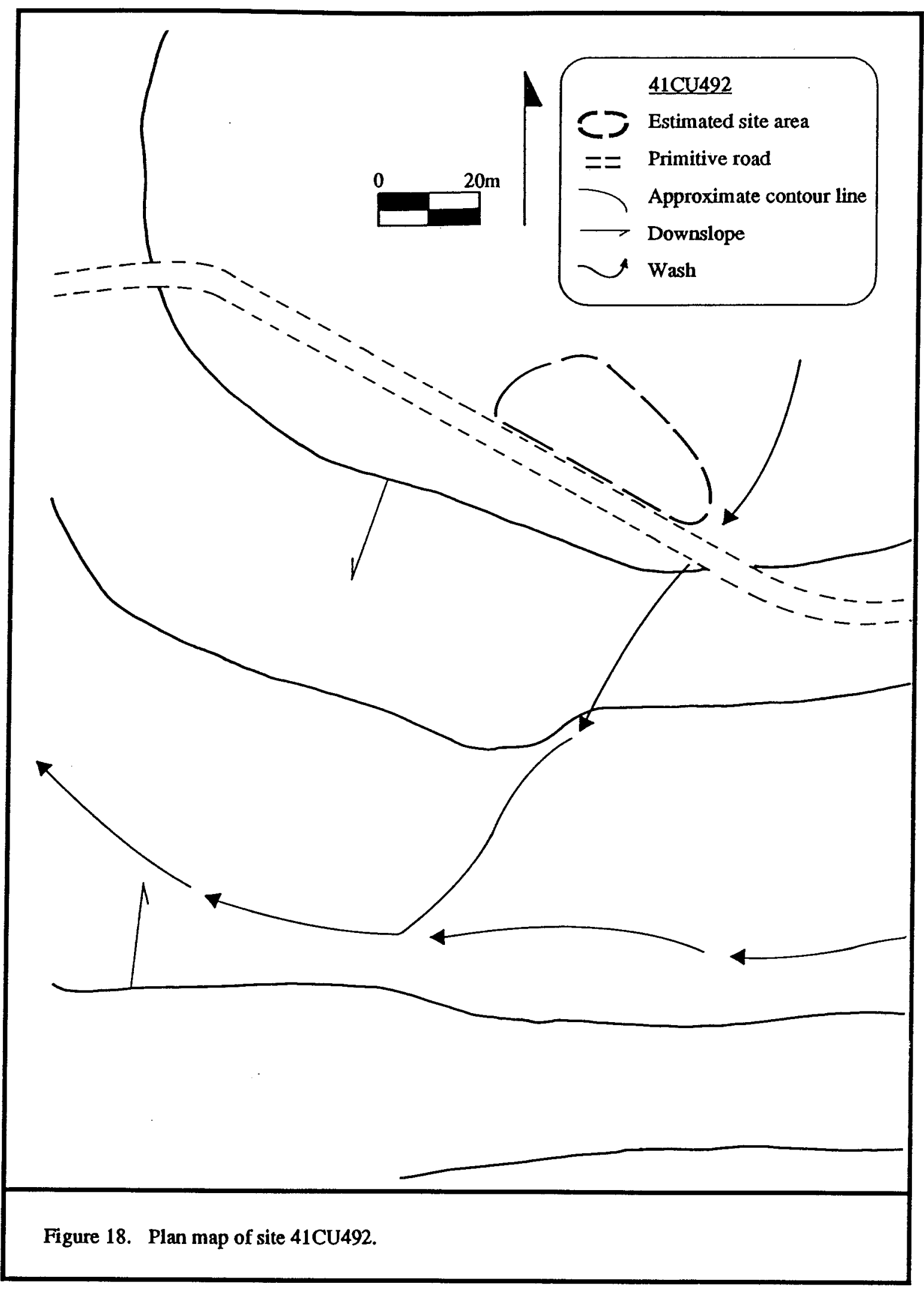


Site 41CU492 was defined by surface observations, with no shovel testing employed. Artifacts were scattered over the entire site area with no concentrations. Surface artifacts include approximately 30 flakes and six tested cobbles. No diagnostic tools were found and all artifacts were produced from chert. No features were observed.

\section{Summary}

Site 41CU492 appears to be a small lithic procurement/reduction site based on the types of artifacts found. No time period can be assigned due to the lack of diagnostic cultural materials. Although the current road repair work will not impact this site further, it is recommended that the site be preserved if possible. Eligibility for this site is presently unknown. Therefore, no further work is recommended at this time for site 41CU492. Nevertheless, if this site is to be affected by future road construction activities, it should be further tested for buried archeological material.

\section{Site $41 \mathrm{CU} 493$}

Site 41CU493 is a moderate to medium density, prehistoric lithic concentration located on top of a long ridge in Culberson County. Drainages run along each side of the ridge and a mountain is located just to the north. The site lies a distance south of the yellow tank on Yellow Tank Road (which runs

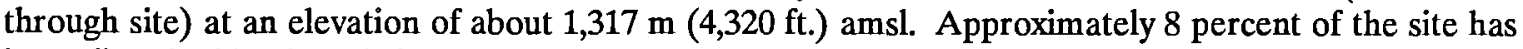
been disturbed by the existing graded roadway, while another 5 percent has been affected by slopewash. Bedrock outcrops in some areas of the site. The site measures approximately $940 \mathrm{~m}$ north-south by $150 \mathrm{~m}$ east-west, covering a total of about 140,000 square meters (Figure 19). The vegetation on the site consists of yucca, cactus, mesquite, creosote, catclaw, and grass. Soils on the site are composed of sandy silts with gravel. It is possible that in some areas of the site there may be some depth to these sediments. The nearest natural water source for the site is an unnamed intermittent stream $90 \mathrm{~m}$ to the east-southeast which flows in a southwesterly direction for $4 \mathrm{~km}$ until it reaches the Green River.

Site 41CU493 was defined by surface observations. Artifacts were scattered over the entire site area with some poorly defined concentrations noted. Surface artifacts include approximately 2,000-2,500 flakes (mostly large, primary flakes), two preform fragments, and 40 tested cobbles. No diagnostics were found and all artifacts were manufactured from chert or agate. No features were observed.

\section{Summary}

Site 41CU493 appears to be a lithic procurement site based on the types of artifacts found. No time period can be assigned due to the lack of diagnostic cultural materials. The current road repair work will not impact this site further, but it is recommended that the site be preserved if possible. Eligibility for this site is unknown at present; however, no further work is recommended at this time. If this site is to be affected by future road improvement activities, then testing should be implemented in order check for buried archeological material.

\section{$\underline{\text { Site } 41 \mathrm{CU} 494}$}

Site 41CU494 is a low-density, prehistoric lithic concentration located on Yellow Tank Road (which runs through the site) in Culberson County. The site is situated on a small ridge nose, a distance south of the yellow tank, at an elevation of about 1,303 m (4,275 ft.) amsl. Approximately 10 percent of the site has been disturbed by the existing graded roadway that runs along the eastern edge of the site area, while an additional 5 percent has been affected by slopewash which has eroded part of the ridge nose. The site measures approximately $30 \mathrm{~m}$ east-west by $45 \mathrm{~m}$ north-south, covering a total area of about 1,350 square meters (Figure 20). Vegetation within the site vicinity consists of creosote, yucca, and 


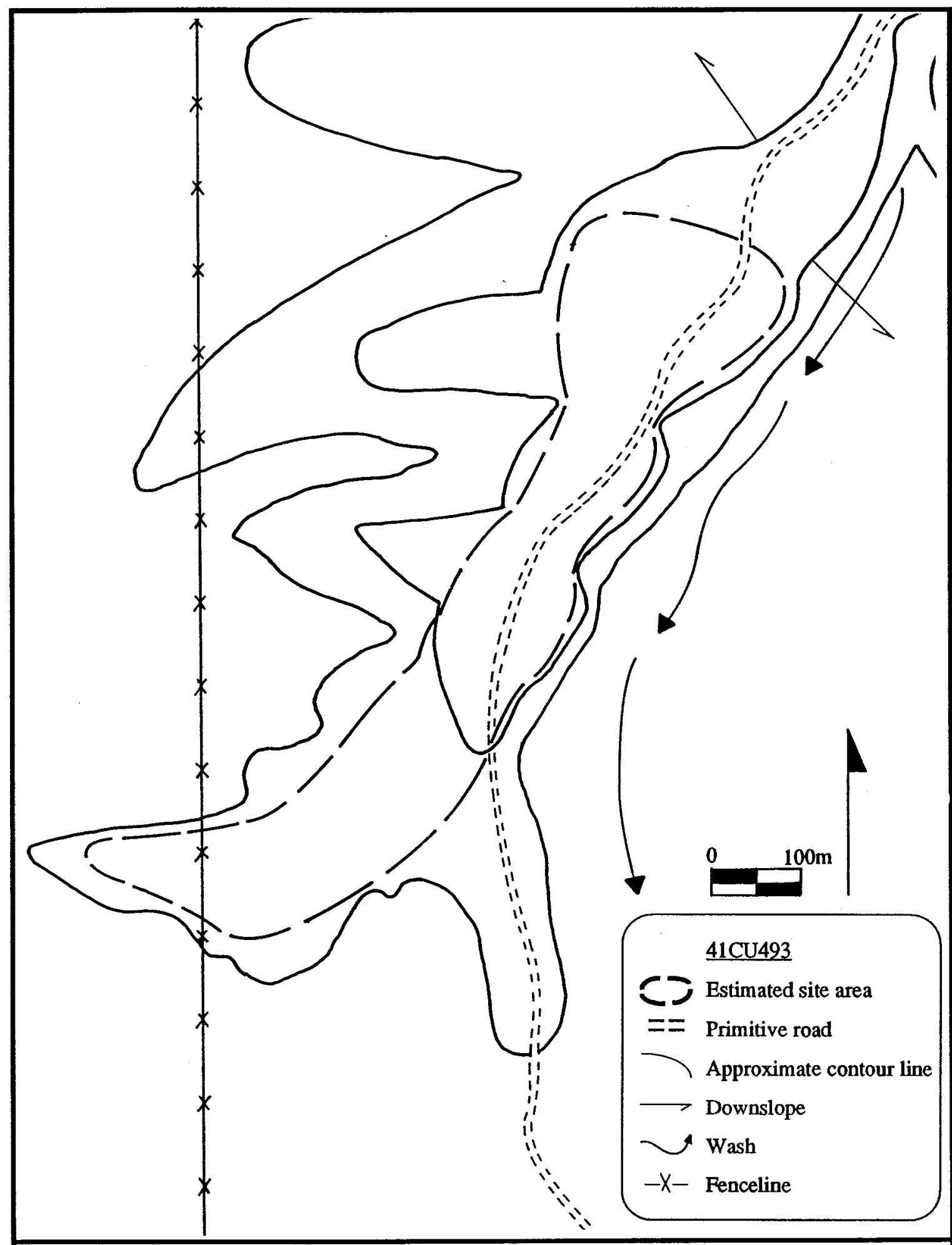

Figure 19. Plan map of site $41 \mathrm{CU} 493$. 


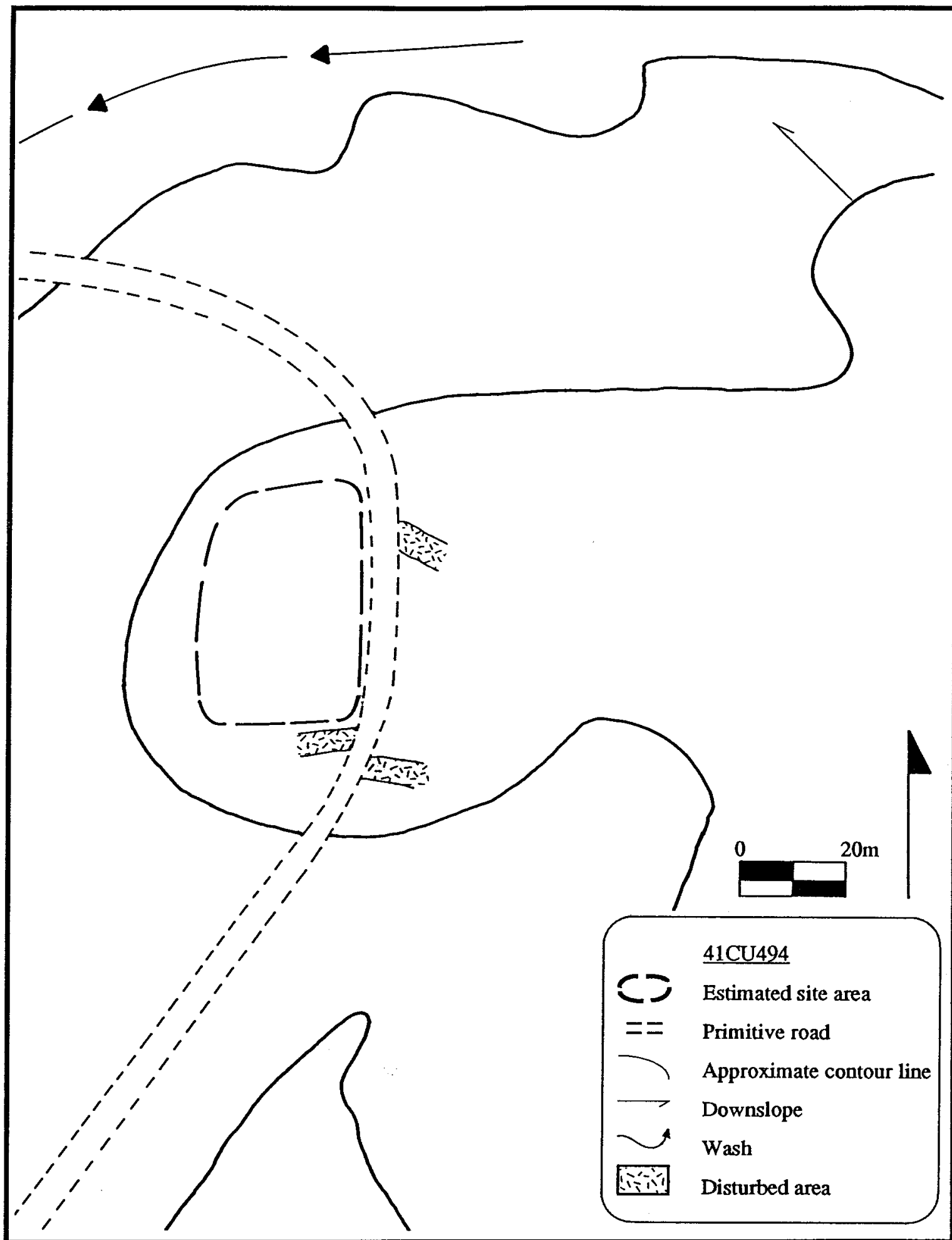

Figure 20. Plan map of site 41 CU 494. 
cactus. The soil on the site is composed of silty sand with gravel, and bedrock outcrops in several areas. The nearest natural water source for the site is an unnamed intermittent stream approximately $100 \mathrm{~m}$ to the northwest which flows in a southwesterly direction for $4 \mathrm{~km}$ until it reaches the Green River.

Site 41 CU494 was defined by surface observation. Artifacts were scattered over the entire site area on a deflated surface. Although poorly defined, a denser concentration of artifactual material was noted toward the center of the site. Approximately 35 flakes were found, of which most were primary. No other artifacts were observed and all flakes were produced from chert. No features were found.

Summary

Site 41CU494 appears to be a small lithic reduction site based on the types of artifacts found. No time period can be assigned due to the lack of diagnostic cultural materials. The current road repair work will not impact this site further, but it is recommended that the site be preserved if possible. This site is considered ineligible for nomination to the NRHP, and as a result, no further work is recommended at this time.

\section{$\underline{\text { Site 41CU495 }}$}

Site 41CU495 is a low-density, prehistoric lithic concentration located in Culberson County on a ridge below a mountain range on Pole Line Road a distance east of the red tank. An unnamed windmill and tank also are located on the site. The site is at an elevation of about 1,364 m (4,474 ft.) amsl. Approximately 10 percent of the site has been disturbed by the existing graded roadway that runs through it and an additional 15 percent has been disturbed by the windmill and tank that are located on the site. In addition, another 5 percent has been affected by slopewash. The site measures approximately $75 \mathrm{~m}$ north-south by $65 \mathrm{~m}$ east-west, covering a total area of about 4,875 square meters (Figure 21). Vegetation consists of cactus, creosote, mesquite, and grass. Soils are composed of sandy silts with gravel. Some bedrock exposures also exist on the site. The nearest natural water source for the site is an unnamed intermittent stream located approximately $100 \mathrm{~m}$ to the southwest, which flows in a southeasterly direction for $2.8 \mathrm{~km}$ until it reaches Van Horn Creek.

Site 41 CU495 was defined by surface observations. Artifacts were lightly scattered over the entire site area on a deflated surface with no concentrations. Surface artifacts include approximately 45 large primary flakes and eight tested cobbles. No diagnostics were found and all artifacts were produced from chert. No features were observed.

Summary

This site appears to be a small lithic reduction site based on the types of artifacts found. No time period can be assigned due to the lack of diagnostic cultural materials. The current road repair work will not impact this site further, but it is recommended that the site be preserved if possible. This site is considered ineligible for nomination to the NRHP, and as a result, no further work is recommended at this time.

\section{Site $41 \mathrm{CU} 496$}

Site 41 CU496 is a low-density, prehistoric lithic concentration located in Culberson County on a flat plain on Lipsey Drag Road just north of the only 90 degree turn on this road. The site is a distance east of Highway US 90 and is situated on a valley floor which runs north-south between two mountain ranges. $41 \mathrm{CU} 496$ is at an elevation of about $1,200 \mathrm{~m}(3,937 \mathrm{ft}$.) amsl. Approximately 10 percent of the site has been disturbed by an existing graded roadway that runs through its middle, while an additional 10 percent has been affected by slopewash. The site measures approximately $30 \mathrm{~m}$ north-south by $45 \mathrm{~m}$ 


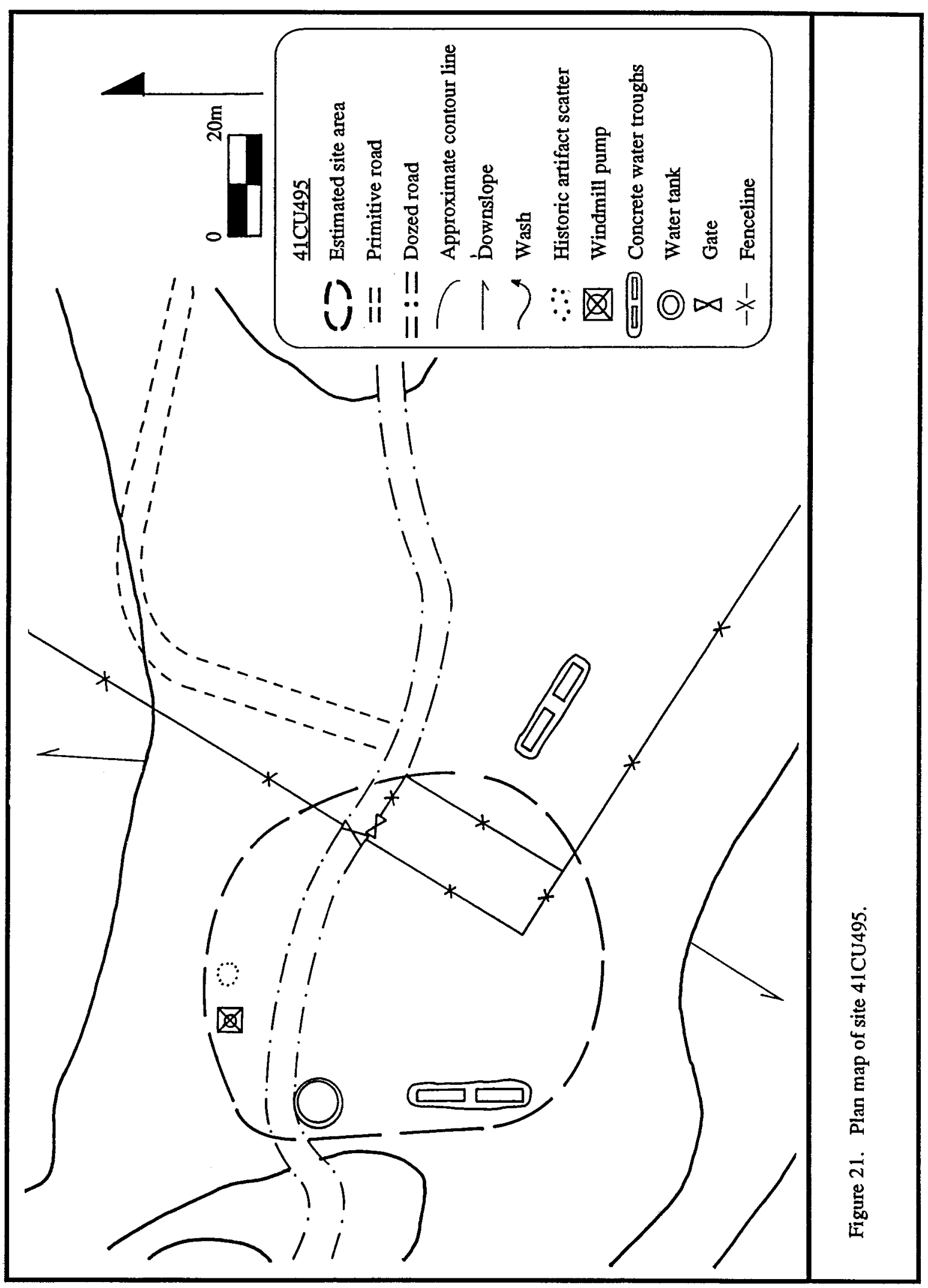


east-west, covering a total area of about 1,350 square meters (Figure 22). Vegetation on the site consists of creosote and cactus, and the soils are composed of silty sands with heavy gravel. The nearest natural water source for the site is an unnamed intermittent stream $150 \mathrm{~m}$ to the northeast which flows in a southeasterly direction for $4.1 \mathrm{~km}$ until it reaches Wild Horse Draw.

Site $41 \mathrm{CU} 496$ was defined by surface observations. Artifacts were lightly scattered over the entire site area. A concentration of artifacts towards the center of the site was noted near a feature. The feature was partially eroded and consisted of fire cracked rock and burned soil. It measured approximately $90 \mathrm{~cm}$ across and probably was a fire hearth (Figure 23). Artifacts found on the surface of site 41CU496 include approximately 45 flakes, one projectile point (which was not relocated for later illustration), one finely worked biface fragment, and one piece of prehistoric pottery. The point was a corner-notched dart point with an expanding stem made from white chert. All of the lithic artifacts were produced from chert. The potsherd was identified as El Paso brownware.

\section{Summary}

Site 41 CU496 appears to be a small, open-air campsite or hunting camp based on the types of artifacts found and the presence of a possible hearth. The dart point and pottery suggest that site $41 \mathrm{CU} 496$ is multicomponent, with an Archaic and Late Prehistoric occupation. At this time it cannot be determined with which component the hearth feature is associated. The current road repair work will not impact this site further, but it is recommended that the site be preserved if possible. Eligibility for this site is presently unknown; however, no further work is recommended at this time. If further construction activity is undertaken which will affect $41 C U 496$, it is recommended that the site be tested to see if buried deposits or features exist.

\section{Site $41 \mathrm{CU} 497$}

Site $41 C U 497$ is a low-density, prehistoric lithic concentration located in Culberson County on a ridge that runs along the side of Green River Road. Allen Ranch Drag Road, which abuts Green River Road on the east side, runs through the center of the site. Two tanks and a windmill are also on the site. Site $41 \mathrm{CU} 497$ is situated in a valley between two mountain ranges at an elevation of about $1,238 \mathrm{~m}$ (4,060 ft.) amsl. Approximately 5 percent of the site has been disturbed by the existing graded roadway that runs through it, while another 6 to 8 percent has been disturbed by the two tanks and the windmill, and an additional 3 percent has been affected by slopewash. The site measures approximately $250 \mathrm{~m}$ north-south by $110 \mathrm{~m}$ east-west, covering a total area of about 27,500 square meters (Figure 24). Vegetation on the site consists of yucca, cactus, mesquite, creosote, and grass. Soils on the site are composed of sandy silts with gravel and some exposed bedrock is also present. The nearest natural water source is an unnamed intermittent stream approximately $40 \mathrm{~m}$ to the southwest which flows in a northeasterly direction for $2.7 \mathrm{~km}$ until it reaches Wild Horse Draw.

Site 41CU497 was defined by surface observations. Artifacts were scattered over the entire site area on a deflated surface with concentrations noted near the top of the ridge along the northern margins. Surface artifacts include approximately 800-900 flakes (mostly large, primary flakes), two preform fragments, and 10 tested cobbles. No diagnostics were found and all artifacts were produced from chert. No features were observed.

\section{Summary}

Site 41CU497 appears to be a low-density lithic procurement site based on the types of artifacts found. No time period can be assigned due to the lack of diagnostic cultural materials. The current road repair work will not impact this site further, but it is recommended that the site be preserved if possible. This 


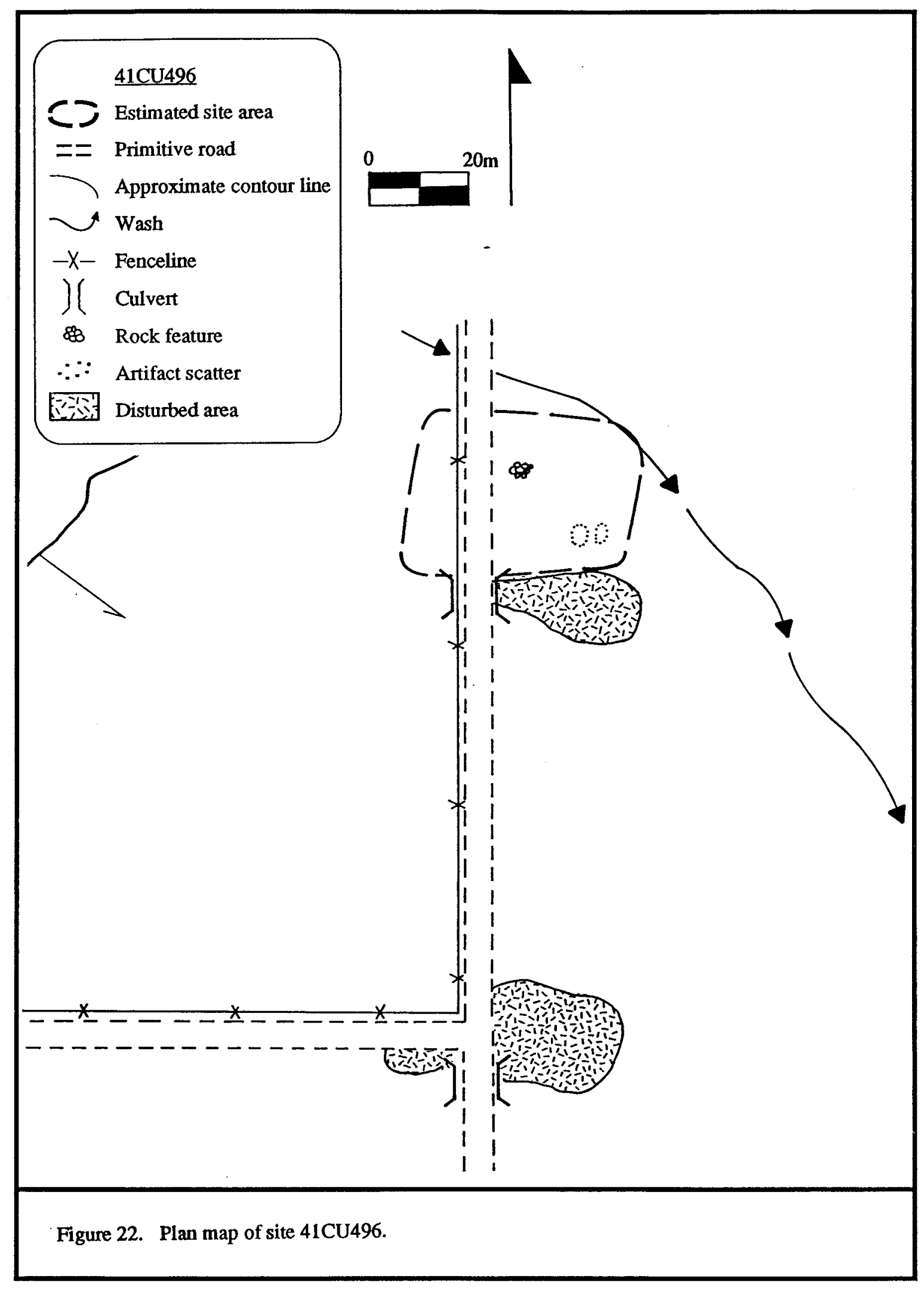




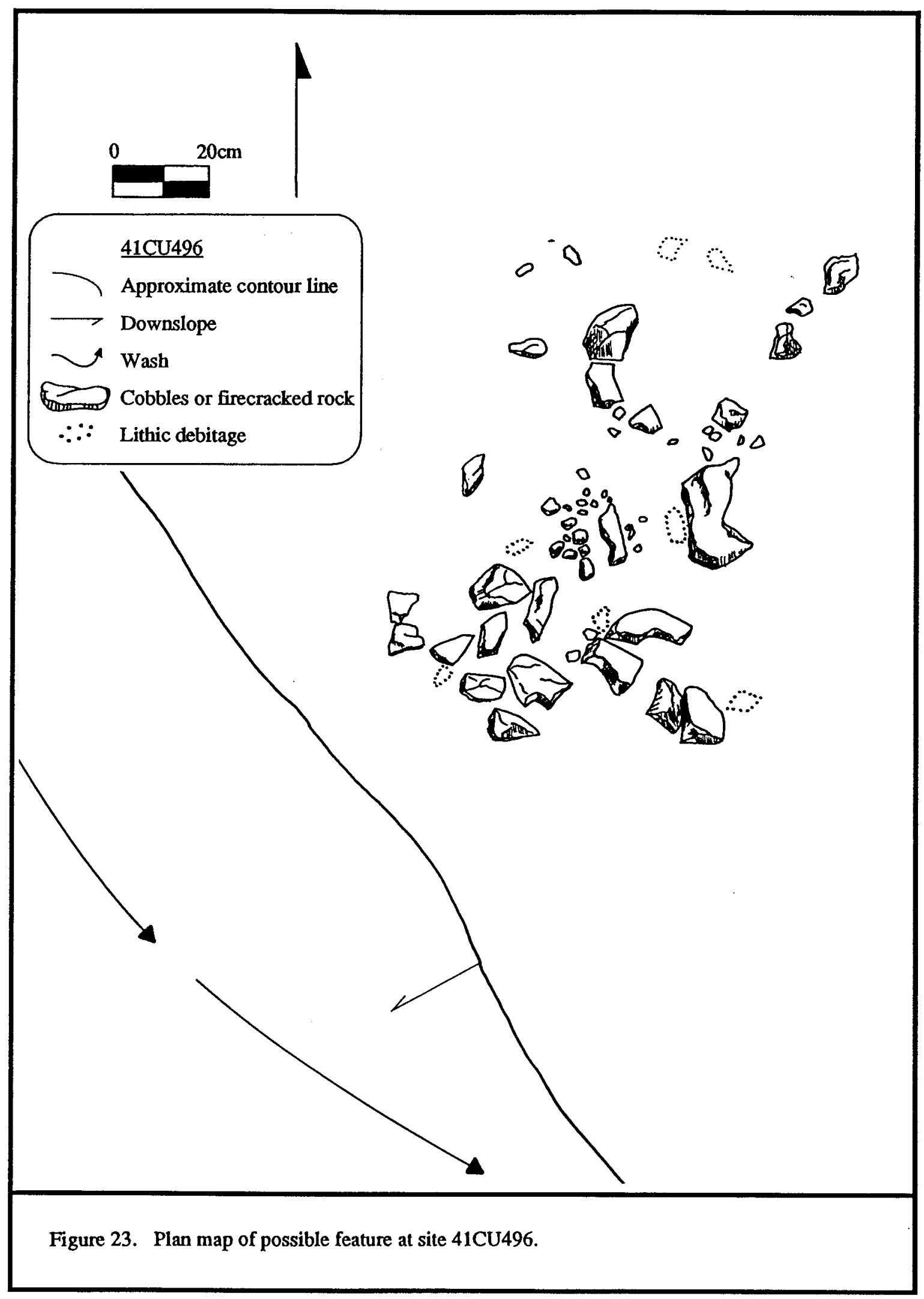




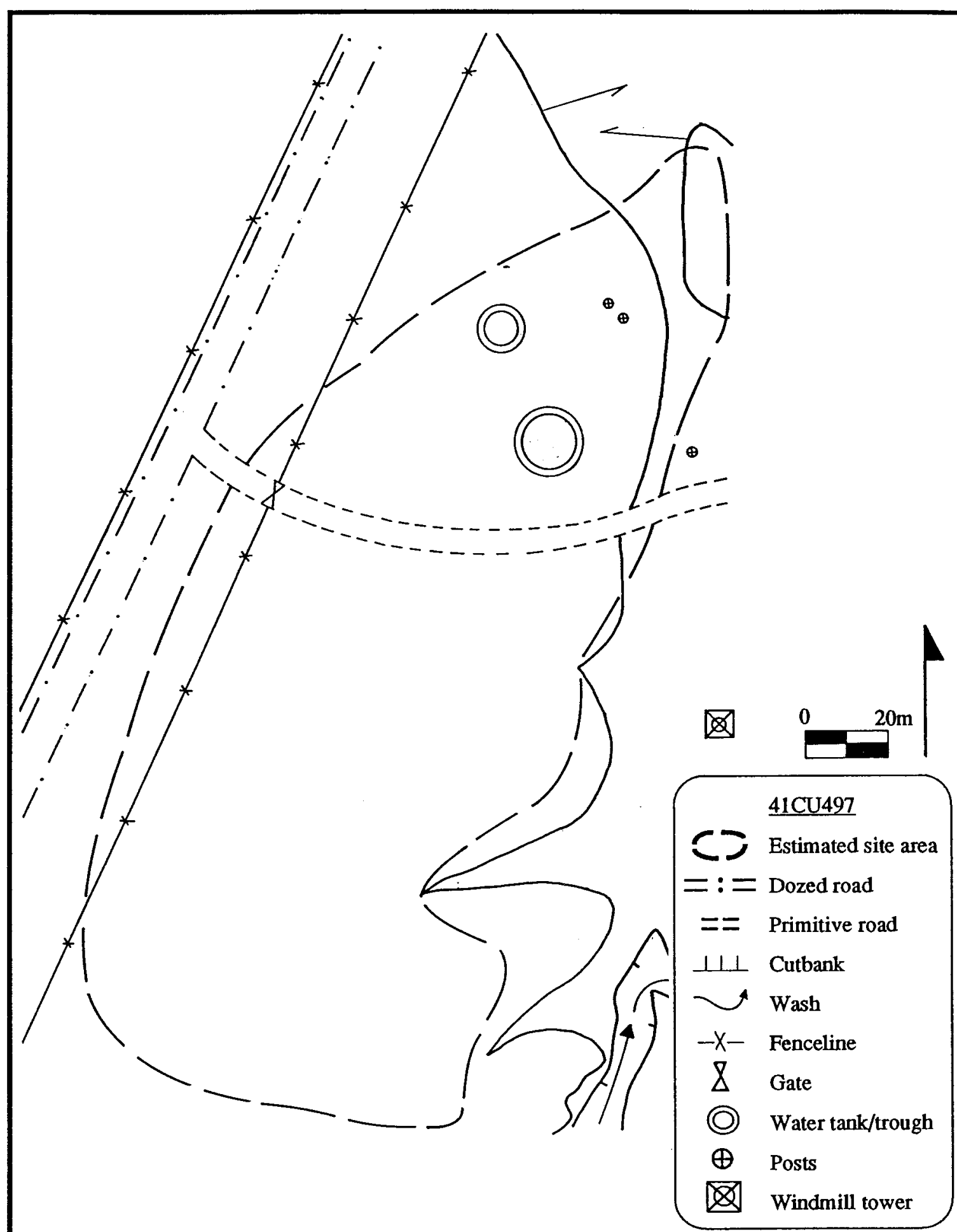

Figure 24. Plan map of site 41CU497. 
site is considered ineligible for nomination to the NRHP, and as a result, no further work is recommended at this time.

\section{Site $41 \mathrm{CU} 498$}

Site 41CU498 is a low-density, prehistoric lithic concentration located in Culberson County (several kilometers southeast of Wilson Canyon) on a long ridge that runs north-south along White Tank Road. White Tank Road runs through the center of the site, which is at an elevation of about $1,119 \mathrm{~m}$ $(3,670 \mathrm{ft}$.) amsl. Approximately 5 percent of the site has been disturbed by the existing graded roadway that runs through it while another 5 percent has been affected by rain erosion and slopewash. The site measures approximately $400 \mathrm{~m}$ north-south by $50 \mathrm{~m}$ east-west, covering a total area of about 20,000 square meters (Figure 25). Vegetation on the site consists of yucca, creosote, mesquite, cactus, and grass. Soils are composed of sandy silts with gravel and some exposed bedrock is also present. The nearest natural water source to the site is an unnamed intermittent stream approximately $20 \mathrm{~m}$ to the east which flows in a southerly direction for $1.1 \mathrm{~km}$ until it reaches Sand Creek.

This site was defined by surface observations. Artifacts were scattered over the entire site area on a deflated surface with some concentrations noted in several areas. Surface artifacts include approximately 800-900 large primary flakes, 10 core fragments, and 40 tested cobbles. All of the artifacts were produced from chert. No diagnostic cultural material or features were found.

\section{Summary}

Site 41CU498 appears to be a low-density lithic procurement site based on the type of artifacts found. No time period can be assigned due to the lack of diagnostic cultural materials. The current road repair work will not impact this site further, but it is recommended that the site be preserved if possible. This site is considered ineligible for nomination to the NRHP, and as a result, no further work is recommended at this time.

\section{$\underline{\text { Site 41JD140 }}$}

Site 41JD140 is a low-density, prehistoric lithic concentration located in Jeff Davis County on a low ridge nose between two mountains on each side of a valley. The site is on "Y" Camp Road (which runs through the site) northwest of Ninety-six Ranch near some windmills and a tank. Site 41JD140 is at an elevation of about $1,238 \mathrm{~m}(4,060 \mathrm{ft}$.) amsl. Approximately 12 percent of the site has been disturbed by an existing graded roadway that runs through it, while an additional 5 percent of the site has been affected by rain washing down sides of the ridge nose. The site measures approximately $64 \mathrm{~m}$ east-west by $17 \mathrm{~m}$ north-south, covering a total area of about 1,088 square meters (Figure 26). Vegetation on and off the site consists of yucca, creosote, cactus, and grass. Soils on the site are composed of silty sands with gravel. A few bedrock exposures also exist on the site. The nearest natural water source from the site is an unnamed intermittent stream, located approximately $60 \mathrm{~m}$ to the south, which flows in a southwesterly direction for $2.4 \mathrm{~km}$ until it reaches Hog Canyon.

Site 41JD140 was defined by surface observations. Artifacts were lightly scattered over the entire site area on a deflated surface with no concentrations. Surface artifacts include approximately 20 flakes (mostly large primary flakes), one core fragment, and three tested cobbles. No diagnostic tools were found and all artifacts were produced from chert. No features were observed.

Summary

Site 41JD140 appears to be a small lithic procurement site based on the types of artifacts found. No time period can be assigned due to the lack of diagnostic cultural materials. The current road repair 


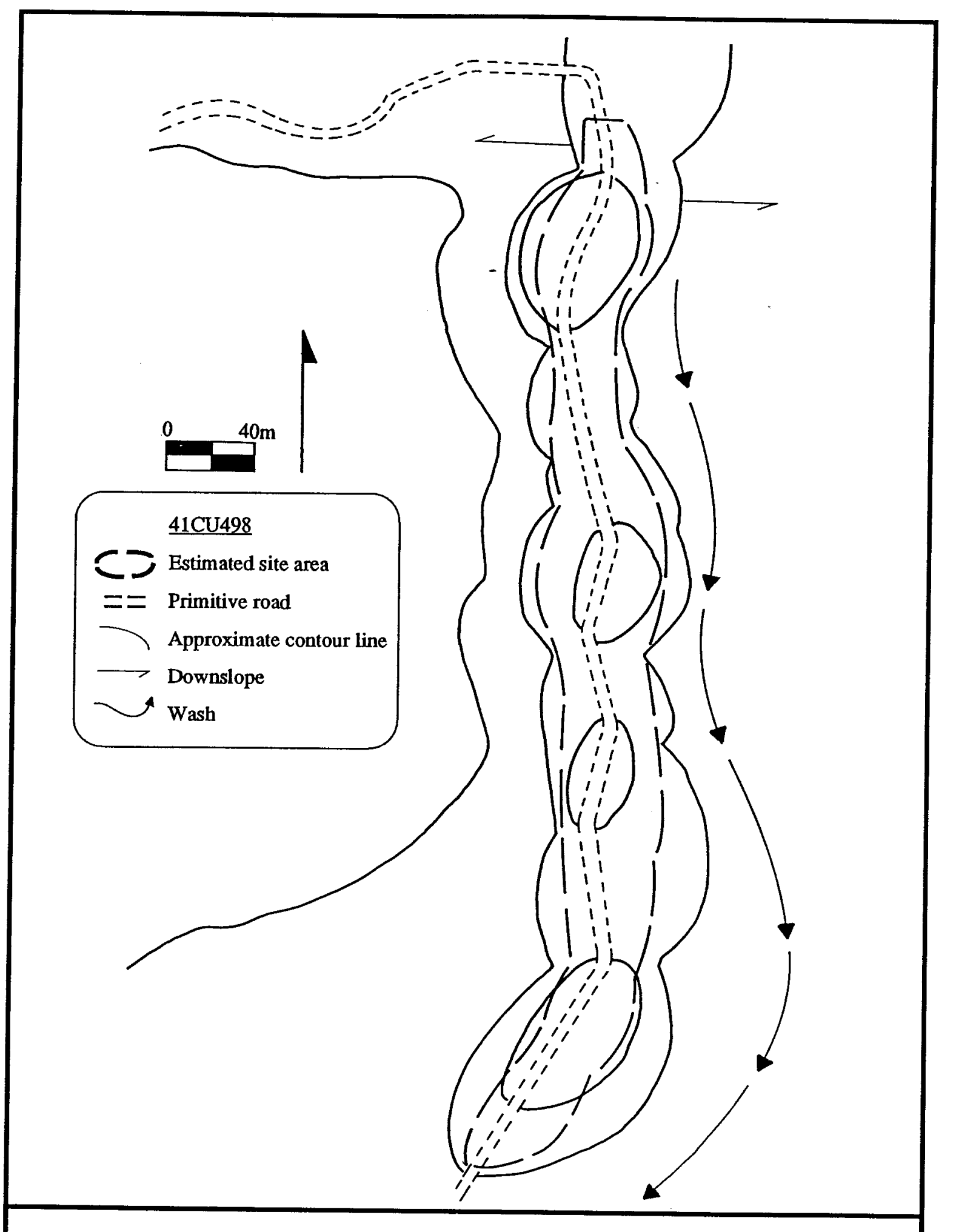

Figure 25. Plan map of site 41CU498. 


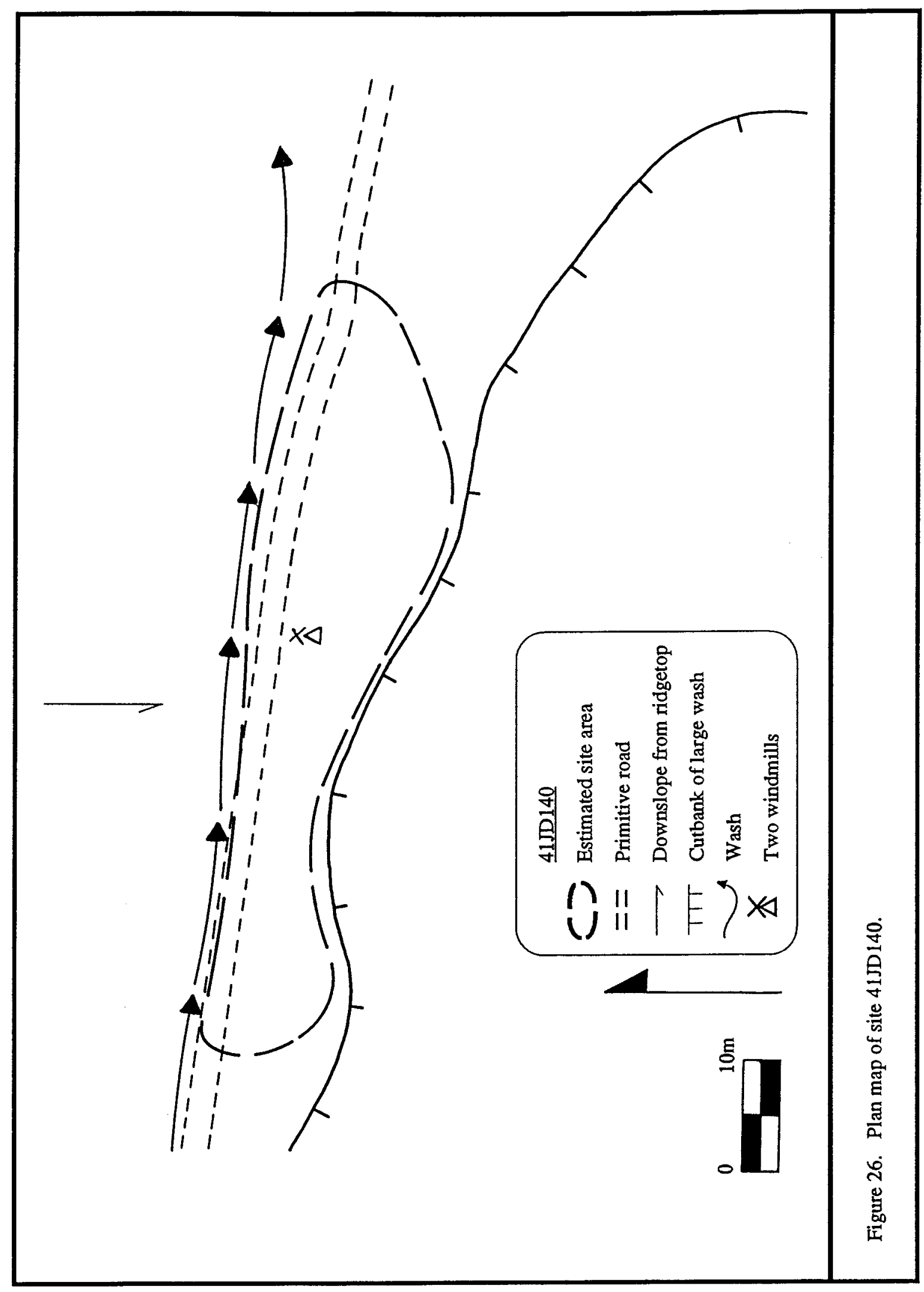


work will not impact this site any further; however, it is recommended that the site be preserved if possible. This site is considered ineligible for nomination to the NRHP, and as a result, no further work is recommended at this time.

\section{$\underline{\text { Site 41JD141 }}$}

Site 41JD141 is a low-density, prehistoric lithic concentration located on a low ridge, northwest of Ninety-six Ranch on "Y" Camp Road in Jeff Davis County. The site overlooks a stream at an elevation of about $1,274 \mathrm{~m}(4,180 \mathrm{ft}$.) amsl with mountains to the north and south. Approximately 15 percent of the site has been disturbed by an existing graded road that runs through the site area. Another 5 percent of the site has been disturbed by slopewash which has cut into the margins of the site. The site measures approximately $90 \mathrm{~m}$ east-west by $65 \mathrm{~m}$ north-south, covering a total area of about 5,850 square meters (Figure 27). Vegetation within the vicinity of site 41JD141 consists of yucca, creosote, mesquite, cactus, and grass. Soils on the site are composed of silty sands with gravel. Bedrock is exposed on the sides of the ridge on which the site is situated. The nearest natural water source for site 41JD141 is an unnamed intermittent stream $50 \mathrm{~m}$ to the south which flows in a southwesterly direction for 1.5 kilometers until it reaches Hog Canyon.

Site 41JD141 was defined by surface observations. Artifacts were scattered over the entire site area on a deflated surface with no apparent concentrations. Surface artifacts include approximately 45 flakes (mostly large primary flakes), one core fragment, and four tested cobbles. No diagnostic tools were found and all artifacts were made from chert. No features were observed.

Summary

Site 41JD141 appears to be a small lithic procurement site based on the types of artifacts found on the site. No time period can be assigned due to the lack of diagnostic cultural materials. The current road repair work will not impact this site further; however, it is recommended that the site be preserved if possible. This site is considered ineligible for nomination to the NRHP, and as a result, no further work is recommended at this time.

\section{Site 41JD142}

Site 41JD142 is a low-density, prehistoric lithic concentration located on a small ridge northwest of Ninety-six Ranch on "Y" Camp Road (which runs through the site) in Jeff Davis County. The site overlooks a small stream that runs between site 41JD141 and this site. Mountains are located to the north and south and some bedrock exposures outcrop on the slopes of the site area. The site is located at an elevation of about 1,274 m (4,180 ft.) amsl. Approximately 15 percent of site $41 \mathrm{JD} 142$ has been disturbed by the existing graded roadway that runs through the site. Another 5 percent has been affected by rain washing down the sides of the ridge which has cut into the site margins. The site measures approximately $40 \mathrm{~m}$ north-south by $45 \mathrm{~m}$ east-west, covering a total area of about 1,800 square meters (Figure 28). Vegetation on and off the site consists of yucca, creosote, mesquite, cactus, and grass. Soils on the site are composed of silty sands with gravel and some bedrock exposures are present. The nearest natural water source for the site is an unnamed intermittent stream $25 \mathrm{~m}$ to the east which flows in a southwesterly direction for $1.5 \mathrm{~km}$ until it reaches Hog Canyon.

Site 41JD142 was defined by surface observations. Artifacts were scattered over the entire site area on a deflated surface with no concentrations. Surface artifacts include approximately 60 flakes (mostly large primary flakes) and five tested cobbles. All artifacts were manufactured from chert. No diagnostic artifacts or features were found. 


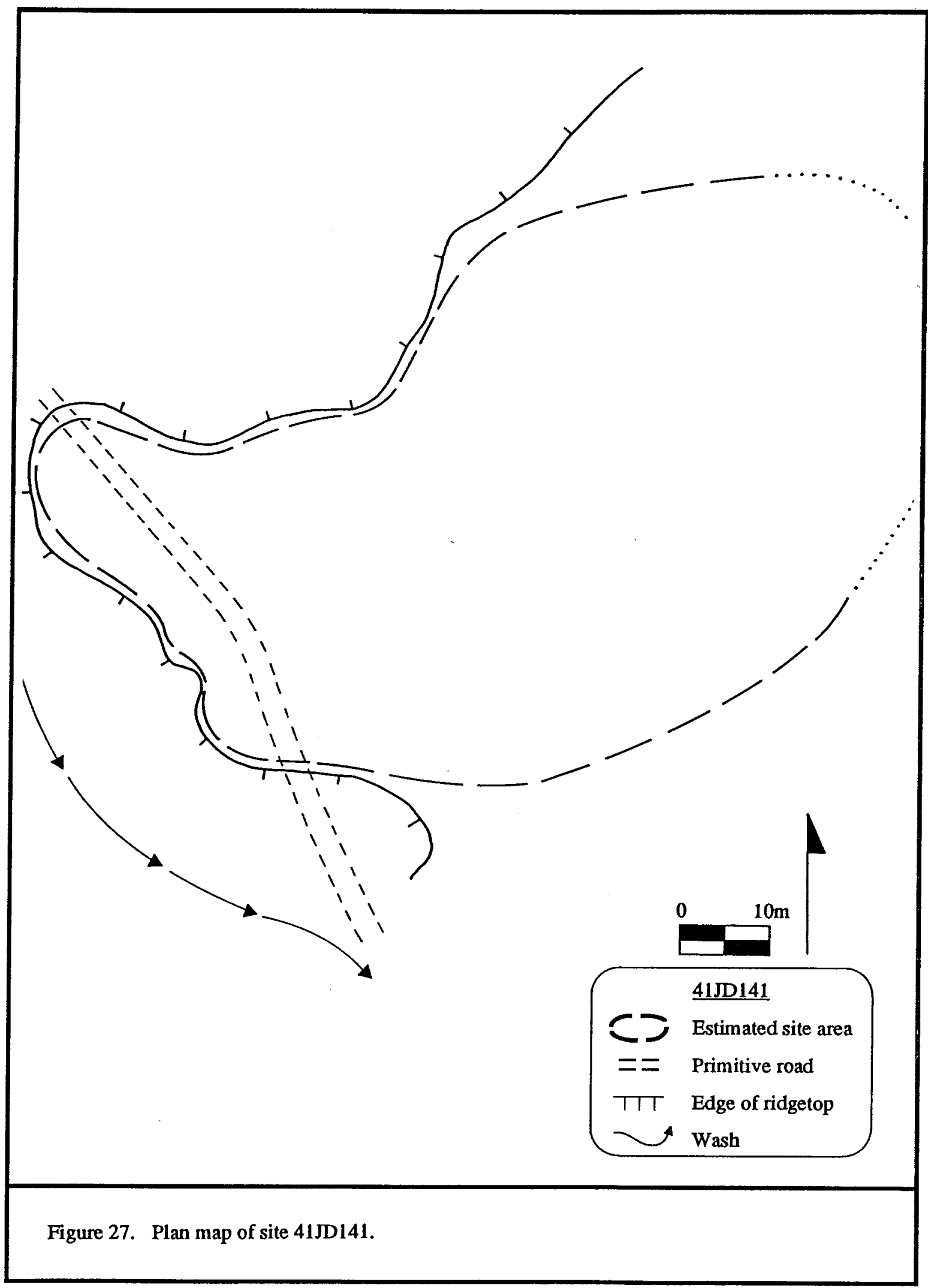




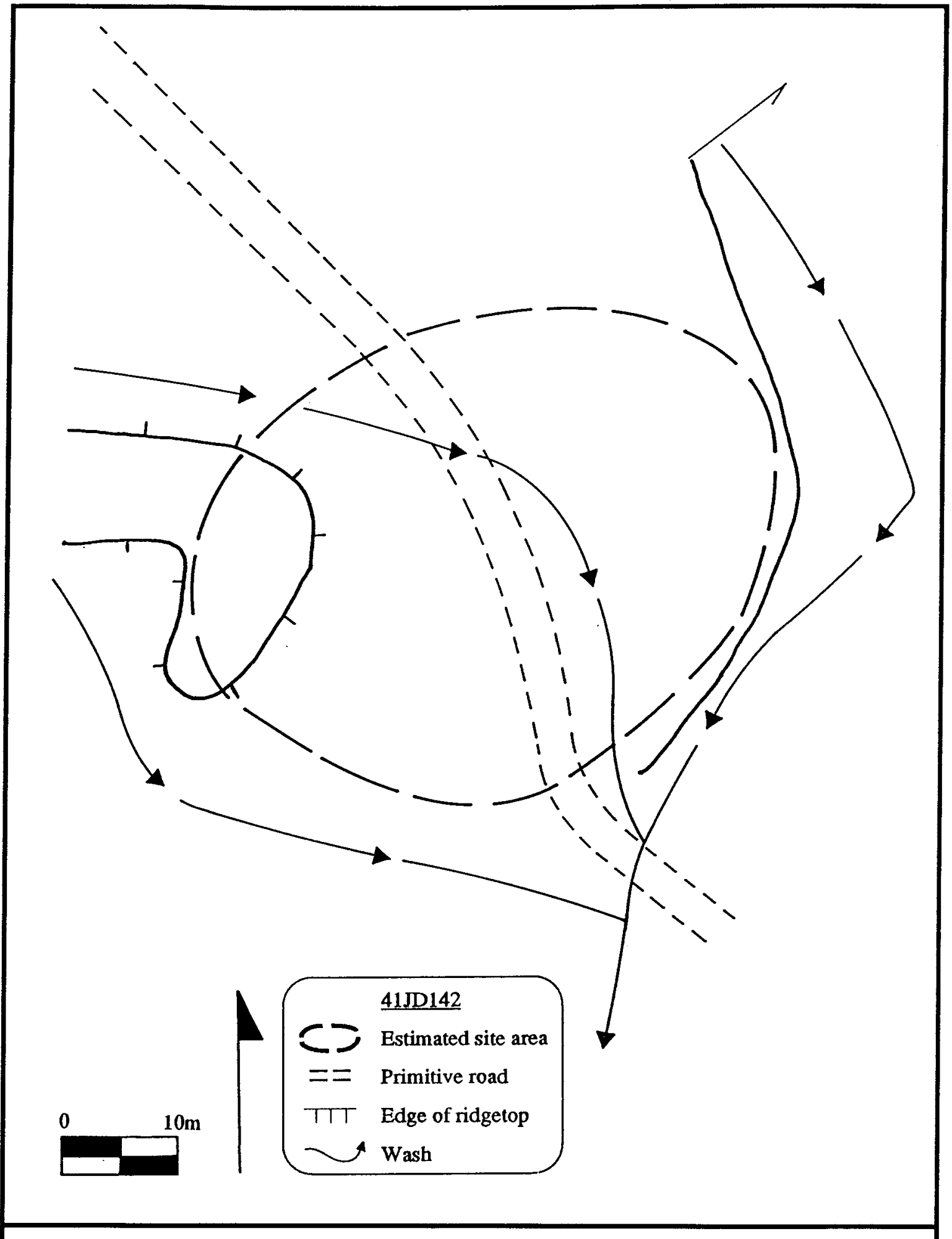

Figure 28. Plan map of site 41JD142. 
Summary

Site 41JD142 appears to be a small lithic procurement site based on the types of artifacts found. No time period can be assigned due to the lack of diagnostic cultural materials. The current road repair work will not impact this site further, but it is recommended that the site be preserved if possible. This site is considered ineligible for nomination to the NRHP, and as a result, no further work is recommended at this time.

\section{Site 41JD143}

Site 41JD143 is a low-density, prehistoric lithic concentration located in Jeff Davis County on an eastwest trending bench on the eastern slopes of the Sierra Vieja Mountains overlooking a valley. The site is a distance northwest of Miller's Ranch on Sierra Vieja Road (the road runs through the site) and is at an elevation of about $1,341 \mathrm{~m}(4,400 \mathrm{ft}$.) amsl. Approximately 10 percent of the site has been disturbed by the existing graded roadway that runs through it, while an additional 3 to 4 percent has been affected by slopewash. The site measures approximately $215 \mathrm{~m}$ east-west by $85 \mathrm{~m}$ north-south, covering a total area of about 18,275 square meters (Figure 29). Vegetation on the site consists of yucca, creosote, cactus, and grass. Site soils are composed of sandy silts with gravel. The nearest natural water source for the site is an unnamed intermittent stream $180 \mathrm{~m}$ to the north which flows in a northeasterly direction for $4.0 \mathrm{~km}$ until it reaches Wild Horse Draw.

Site 41JD143 was defined by surface observations. Artifacts were scattered over the entire site area on a deflated surface with no concentrations. Surface artifacts include approximately 200 flakes (mostly large, primary flakes), one biface fragment, and several tested cobbles. No diagnostic tools were found and all artifacts were knapped from chert. No features were observed.

\section{Summary}

Site 41JD143 appears to be a low-density lithic procurement site based on the types of artifacts found. No time period can be assigned due to the lack of diagnostic cultural materials. The current road repair work will not impact this site further, but it is recommended that the site be preserved if possible. This site is considered ineligible for nomination to the NRHP, and as a result, no further work is recommended at this time.

\section{Site 41JD144}

Site 41JD144 is a low-density, prehistoric lithic concentration located alongside Sierra Vieja Road in Jeff Davis County on a valley floor. The site is a moderate distance east of $41 \mathrm{JD} 143$ at an elevation of about

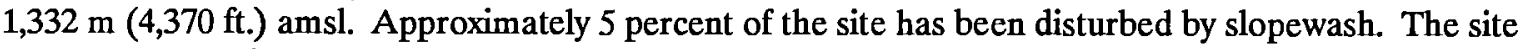
measures approximately $40 \mathrm{~m}$ north-south by $30 \mathrm{~m}$ east-west, covering a total area of about 1,140 square meters (Figure 30). Vegetation within the site vicinity consists of yucca, creosote, and grass. Soils on the site are composed of sandy silts with gravel. Bedrock exposures are also present. The nearest natural water source for the site is an unnamed intermittent stream approximately $500 \mathrm{~m}$ to the north which flows to the northeast and then spreads out over the valley floor of Wild Horse Draw.

Site 41JD144 was defined by surface observations. Artifacts were scattered over the entire site area on a deflated surface with no concentrations. Surface artifacts include approximately $\mathbf{4 0}$ flakes, consisting mostly of secondary and pressure flakes. All flakes were produced from chert. No features were observed. 


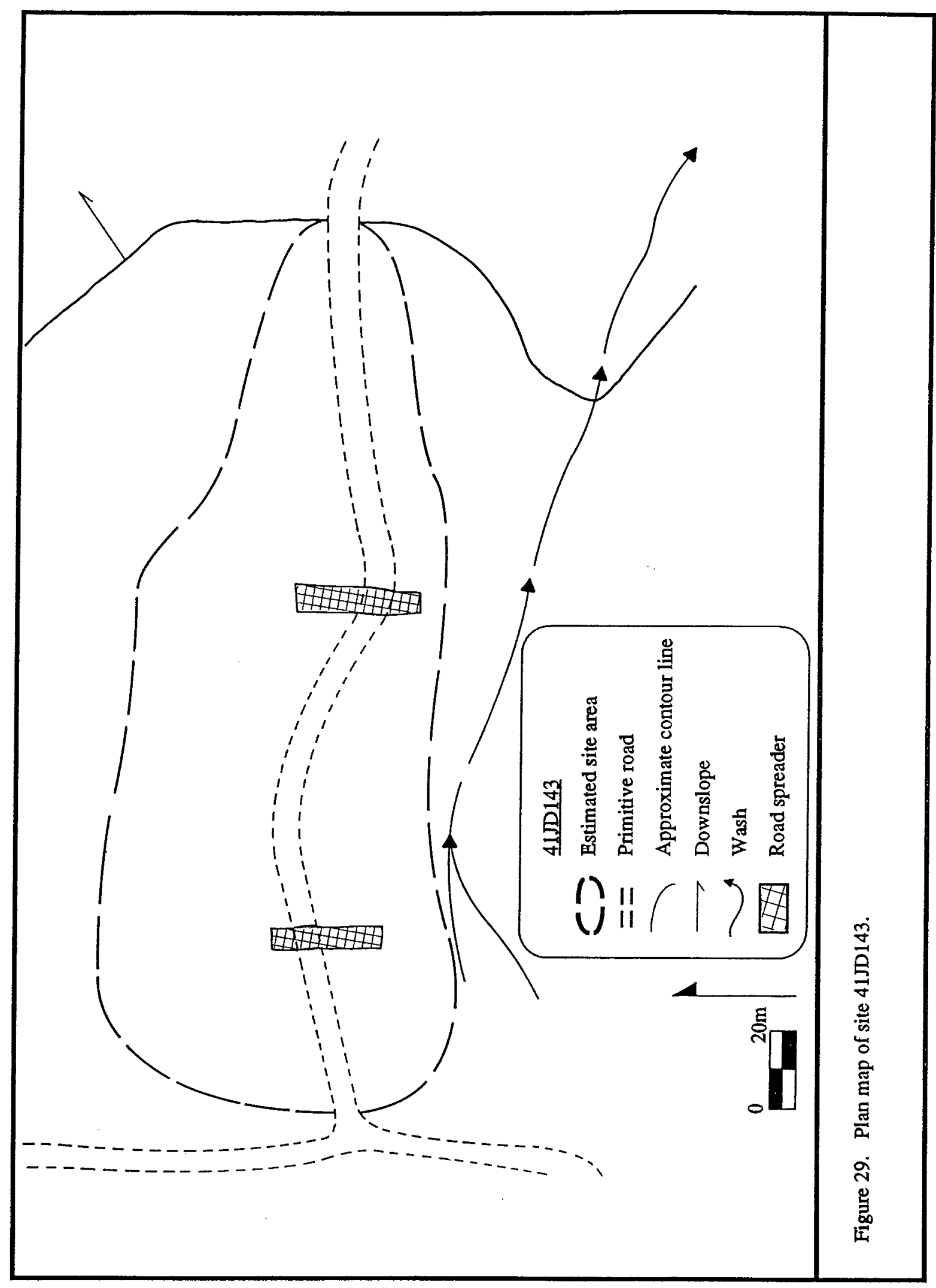




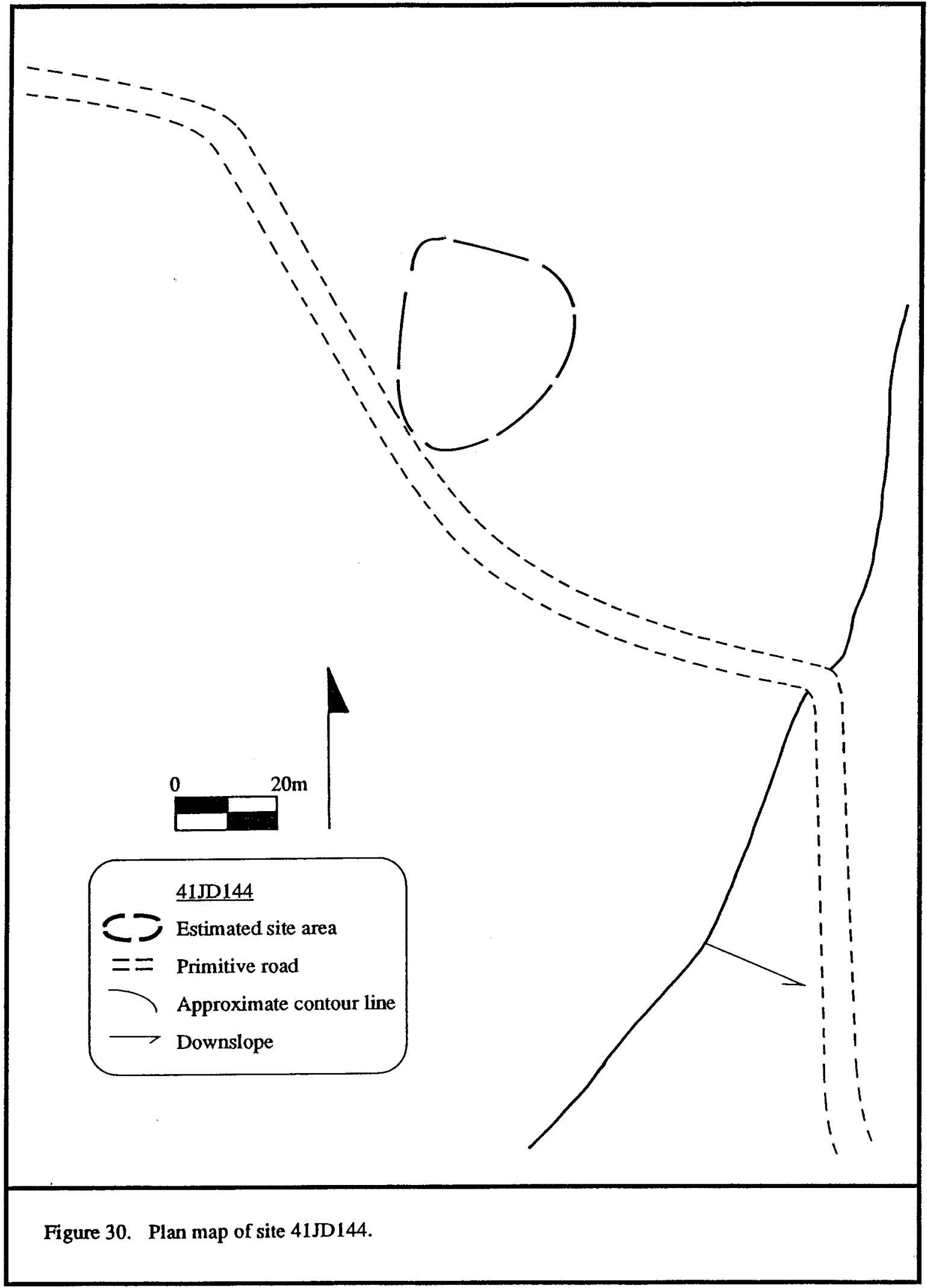




\section{Summary}

Site 41JD144 appears to be a small lithic reduction or open-air campsite based on the types of artifacts found. No time period can be assigned due to the lack of diagnostic cultural materials. The current road repair work will not impact this site further, but it is recommended that the site be preserved if possible. This site is considered ineligible for nomination to the NRHP, and as a result, no further work is recommended at this time.

\section{Site 41JD145}

Site 41JD145 is a low-density, prehistoric lithic concentration located in Jeff Davis County on White Tank Road on a ridge approximately $5 \mathrm{~km}$ southeast of Wilson Canyon. The site is surrounded by mountains and is at an elevation of about $1,097 \mathrm{~m}(3,600 \mathrm{ft}$.) amsl. White Tank Road runs through the middle of the site. Approximately 10 percent of the site has been disturbed by the existing graded roadway and another 3 to 4 percent has been disturbed by slopewash. The site measures approximately $85 \mathrm{~m}$ east-west by $30 \mathrm{~m}$ north-south, covering a total area of about 3,150 square meters (Figure 31). Vegetation on the site consists of yucca, creosote, cactus, and grass. Soils on the site are composed of sandy silts with heavy gravel and some bedrock exposures are also present. The nearest natural water source to the site is an unnamed intermittent stream approximately $40 \mathrm{~m}$ to the south which flows in a southwesterly direction for $2 \mathrm{~km}$ until it reaches Sand Creek.

This site was defined by surface observations. Artifacts were scattered over the entire site area on a deflated surface with no concentrations. Surface artifacts include approximately 30 large primary flakes, two core fragments, and 10 tested cobbles. All of the artifacts were produced from chert. No diagnostic tools or features were found.

\section{Summary}

Site 41JD145 appears to be a low-density lithic procurement/reduction site based on the types of artifacts found. No time period can be assigned due to the lack of diagnostic cultural materials. The current road repair work will not impact this site further, but it is recommended that the site be preserved if possible. This site is considered ineligible for nomination to the NRHP, and as a result, no further work is recommended at this time.

\section{Site 41JD146}

Site 41JD146 is a low-density, prehistoric lithic concentration located in Jeff Davis County on White Tank Road on a north-south running ridge which is surrounded by mountains. The site is situated east a short distance from site 41JD145 at an elevation of about 1,138 m (3,734 ft.) amsl. Approximately 10 percent of the site has been disturbed by the existing graded roadway and an additional 5 percent has been affected by slopewash. The site measures approximately $230 \mathrm{~m}$ north-south by $40 \mathrm{~m}$ east-west, covering a total area of about 9,200 square meters (Figure 32). The vegetation within the site vicinity consists of yucca, cactus, mesquite, creosote, and grass. Soils on the site are composed of sandy silts with gravel and some bedrock exposures are also present. The nearest natural water source to the site is an unnamed intermittent stream located approximately $100 \mathrm{~m}$ to the north, which flows in a southwesterly direction for $2.1 \mathrm{~km}$ until it reaches Sand Creek.

This site was defined by surface observations. Artifacts were scattered over the entire site area on a deflated surface with a concentration noted on the northern end. Surface artifacts include approximately 25 large primary flakes, two core fragments, and five tested cobbles. No diagnostic tools were found and all artifacts were manufactured from chert. No features were observed. 


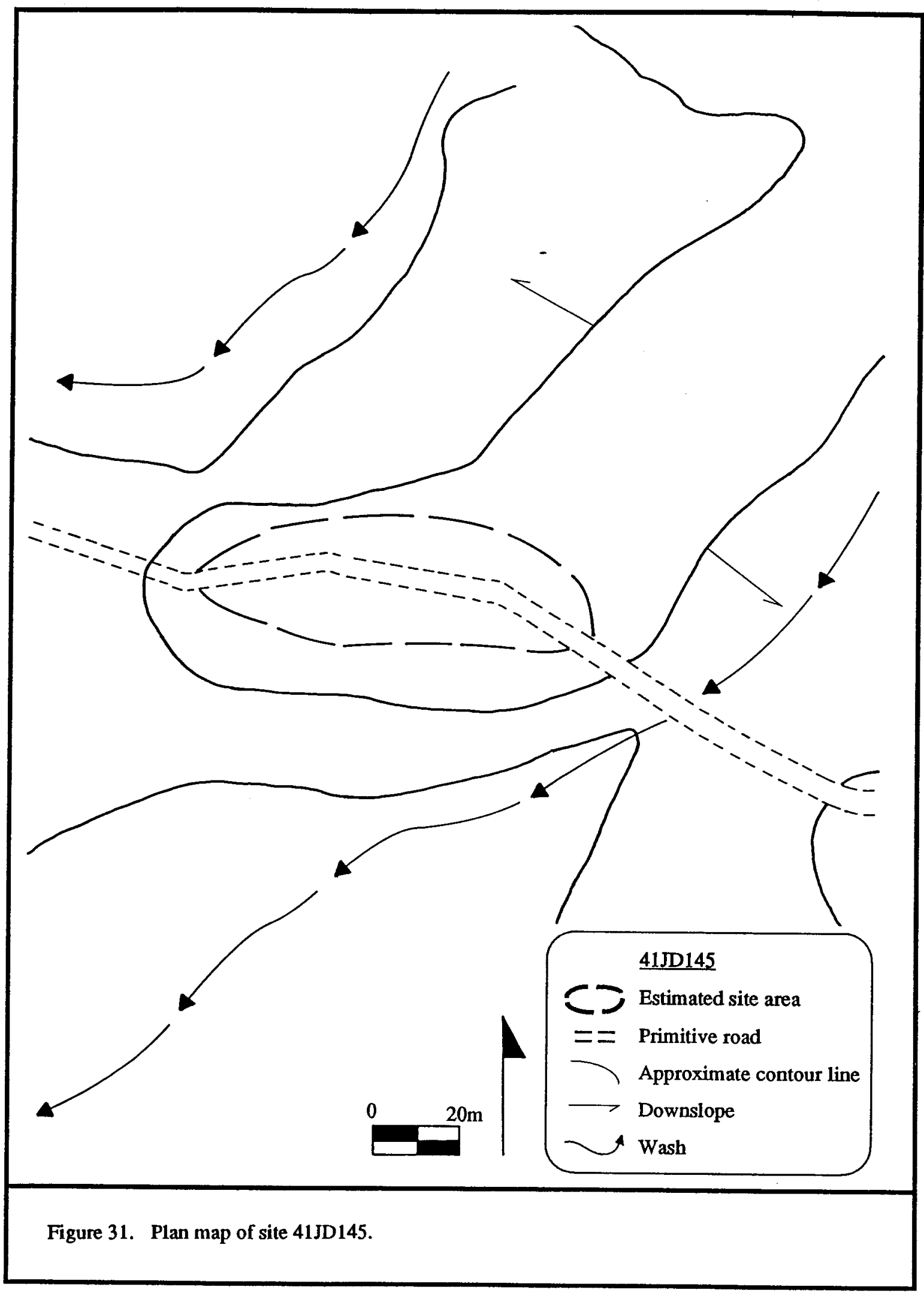




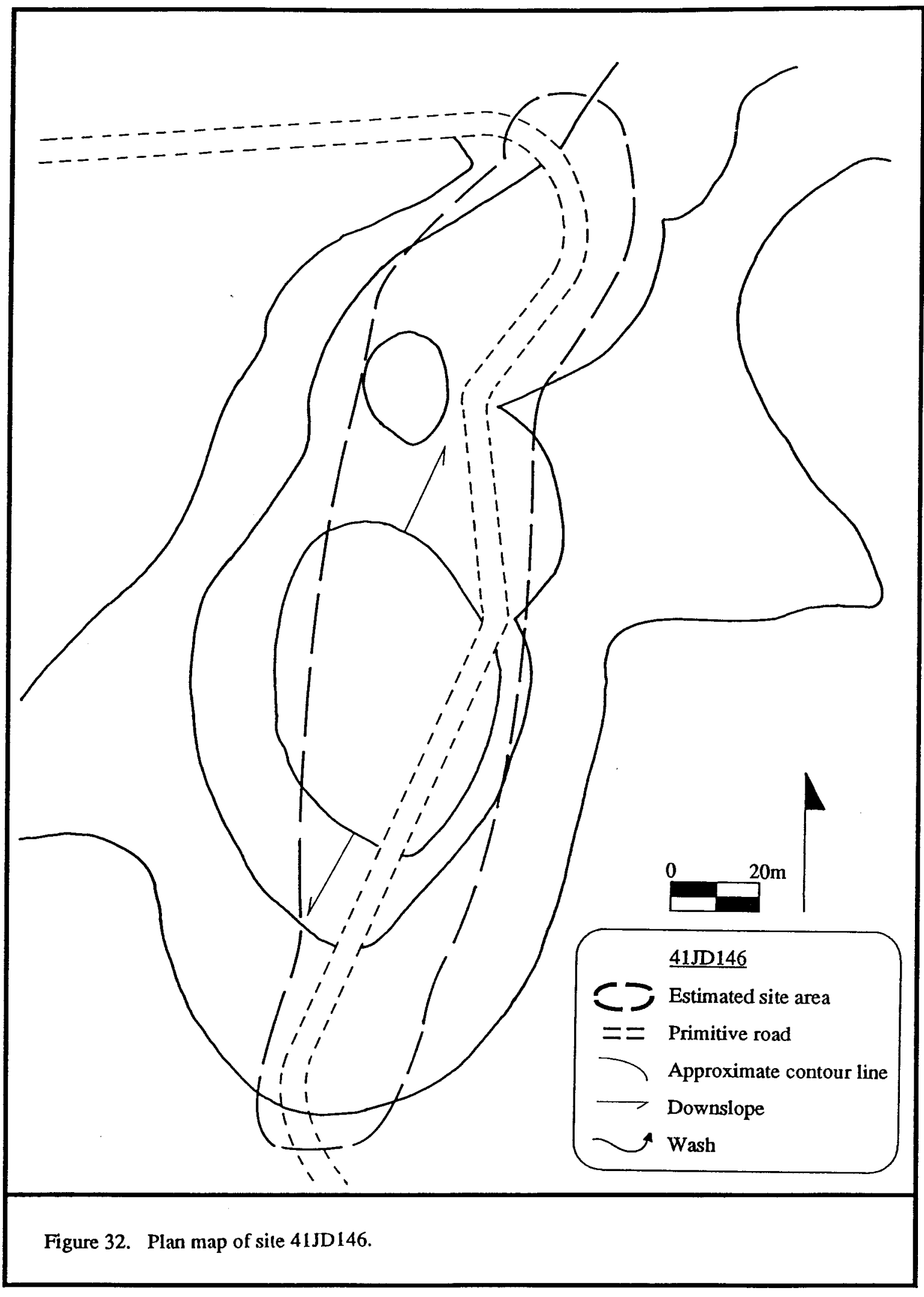


Site 41JD146 appears to be a low-density lithic procurement/reduction site based on the types of artifacts found. No time period can be assigned due to the lack of diagnostic cultural materials. The current road repair work will not impact this site further, but it is recommended that the site be preserved if possible. This site is considered ineligible for nomination to the NRHP, and as a result, no further work is recommended at this time.

\section{$\underline{\text { Site 41JD147 }}$}

Site 41JD147 is a low-density, prehistoric lithic concentration located in Jeff Davis County on a ridge nose which overlooks a drainage. The site is on White Tank Road several hundred meters southeast of site 41JD146 at an elevation of about 1,091 m (3,580 ft.) amsl. White Tank Road runs through the middle of the site. Approximately 10 percent of the site has been disturbed from the existing graded roadway that runs through its center, while another 3 to 4 percent has been affected by slopewash which has eroded part of the ridge nose. The site measures approximately $145 \mathrm{~m}$ north-south by $30 \mathrm{~m}$ eastwest, covering a total area of about 4,350 square meters (Figure 33). Vegetation on and off the site consists of yucca, creosote, mesquite, cactus, and grass. Soils on the site are composed of sandy silts with gravel. The nearest natural water source for the site is an unnamed intermittent stream $20 \mathrm{~m}$ to the east which flows in a southerly direction for $3 \mathrm{~km}$ until it reaches $\mathrm{Hog}$ Canyon.

This site was defined by surface observations. Artifacts were lightly scattered over the entire site area on a deflated surface with no concentrations. Surface artifacts include approximately 30 large primary flakes, two core fragments, and five tested cobbles. All artifacts were knapped from chert. No diagnostic tools or features were observed.

\section{Summary}

Site 41JD147 appears to be a low-density lithic procurement/reduction site based on the kinds of artifacts found. No time period can be assigned due to the lack of diagnostic cultural materials. The current road repair work will not impact this site further; however, it is recommended that the site be preserved if possible. This site is considered ineligible for nomination to the NRHP, and as a result, no further work is recommended at this time.

\section{Site 41PS561}

Site 41PS561 is a moderate to medium density, prehistoric lithic concentration located in Presidio County on a small bench above a flowing stream (to the southeast of the bench) not far from a twotrack road that leads to Camp Holland. The site is on Sierra Vieja Road (which runs through the middle of the site) east from Miller's Ranch at an elevation of about 1,366 m (4,480 ft) amsl. Approximately 15 percent of the site has been disturbed by a graded road which cuts through the center, and an additional 5 percent has been affected by slopewash which has cut into the edge of the site. The site measures approximately $120 \mathrm{~m}$ north-south by $55 \mathrm{~m}$ east-west, covering a total area of about 6,600 square meters (Figure 34). Vegetation within the site vicinity consists of yucca, cactus, and grass. Soils on the site are composed of sands with heavy gravel and some bedrock exposures are also present. The nearest natural water source for the site is an unnamed stream, located approximately $80 \mathrm{~m}$ to the south, which feeds out from Z H Canyon located immediately southwest of the site.

Site 41PS561 was defined by surface observations. Based on general surface observations, some of the archeological deposits on this site may have some depth. Artifacts were scattered over the entire site area with a poorly defined concentration noted toward the center of the site. Artifacts include 


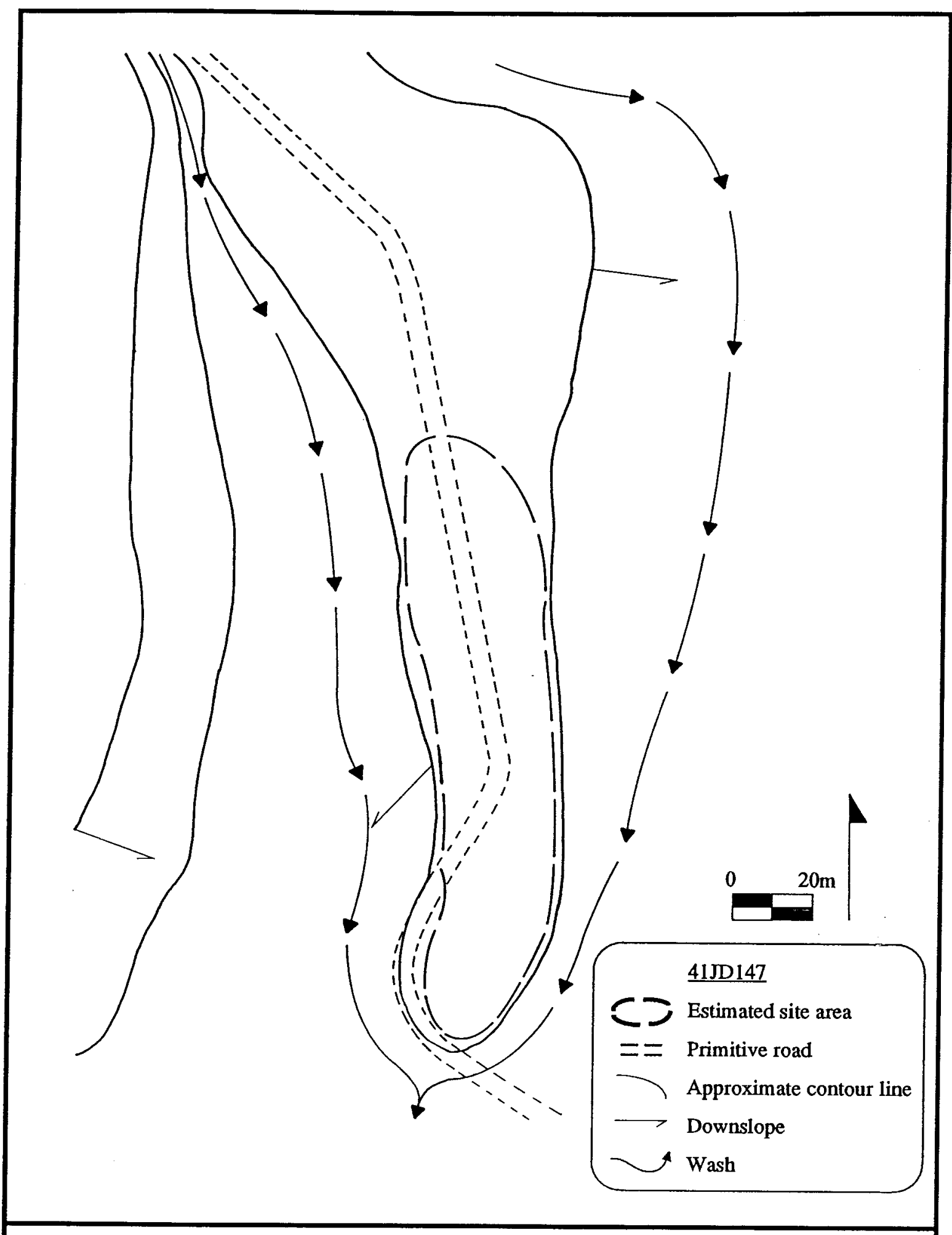

Figure 33. Plan map of site 41JD147. 


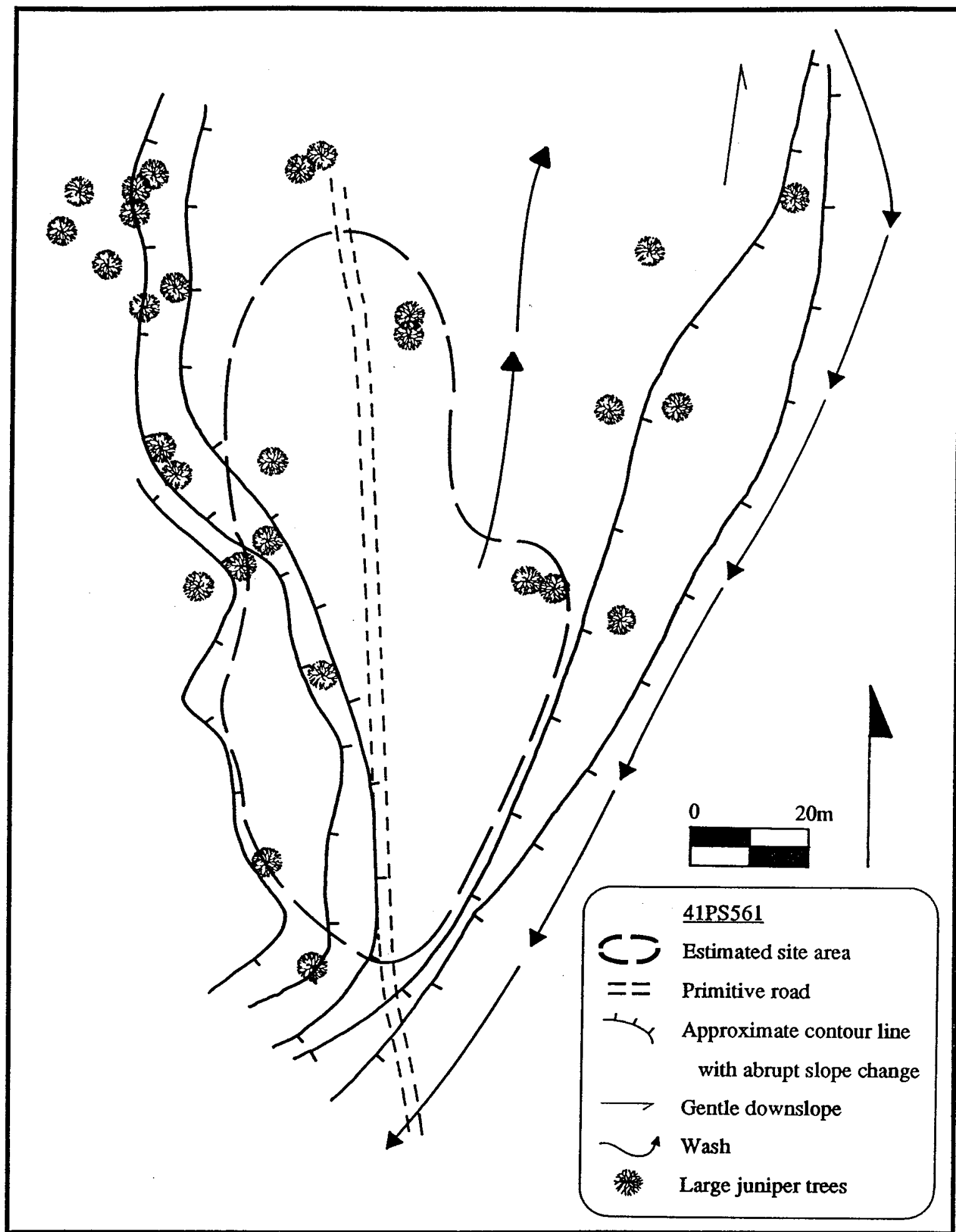

Figure 34. Plan map of site 41PS561. 
approximately 225 flakes, 10 biface fragments (both mid-sections and tips), and six core fragments. All artifacts were produced from chert. No diagnostic tools or features were found.

Summary

Site 41PS561 appears to be a moderate to medium density, open-air campsite based on the types of artifacts found. No time period can be assigned due to the lack of diagnostic artifacts. The current road work will not impact this site further; however, it is recommended that site 41PS561 be preserved if possible. Eligibility for this site is presently unknown; however, no further work is advised at this time. If further construction activity occurs, it is recommended that this site be tested to determine whether buried deposits exist.

\section{Site 41PS562}

Site 41PS562 is a moderate to medium density, prehistoric lithic concentration located in Presidio County on a low ridge just below a mountain range on Sierra Vieja Road southwest of Miller's Ranch.

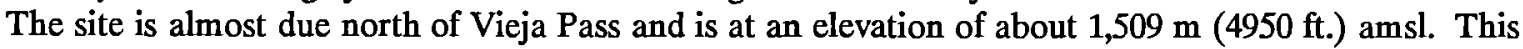
site has been subjected to some disturbance, with 7 percent of the area affected by an existing graded roadway that runs through the middle of the site. Another 5 percent of the site has been disturbed by slopewash. The site measures approximately $240 \mathrm{~m}$ north-south by $70 \mathrm{~m}$ east-west, covering a total area of about 16,800 square meters (Figure 35). The vegetation on the site consists of creosote, mesquite, cactus, and grass. Soils on the site are composed of silty sands and silty sands with gravel. Based on observations along the road cut, some of the sediments on the site were $10 \mathrm{~cm}$ thick. The nearest natural water source for the site is an unnamed intermittent steam approximately $60 \mathrm{~m}$ to the southwest which flows a short distance south into Cottonwood Canyon.

Site 41PS562 was located by surface observations. Artifacts were scattered over the entire site area with a slight concentration noted on the southern side. Surface artifacts include approximately 250 to 350 flakes (some pressure flakes), 10 biface fragments (including both mid-sections and tips), and four scrapers (two endscrapers and two sidescrapers). No diagnostic tools were observed and all artifacts were manufactured from chert. No features were found.

\section{Summary}

Site 41PS562 appears to be an open-air campsite based on the types of artifacts found. No time period can be assigned due to the lack of diagnostic cultural materials. The current road repair work will not impact this site, but it is recommended that the site be preserved if possible. Eligibility for this site is presently unknown; however, no further work is recommended at this time. If the site is to be impacted by future road construction, then testing is recommended to determine whether buried deposits or features exist. 


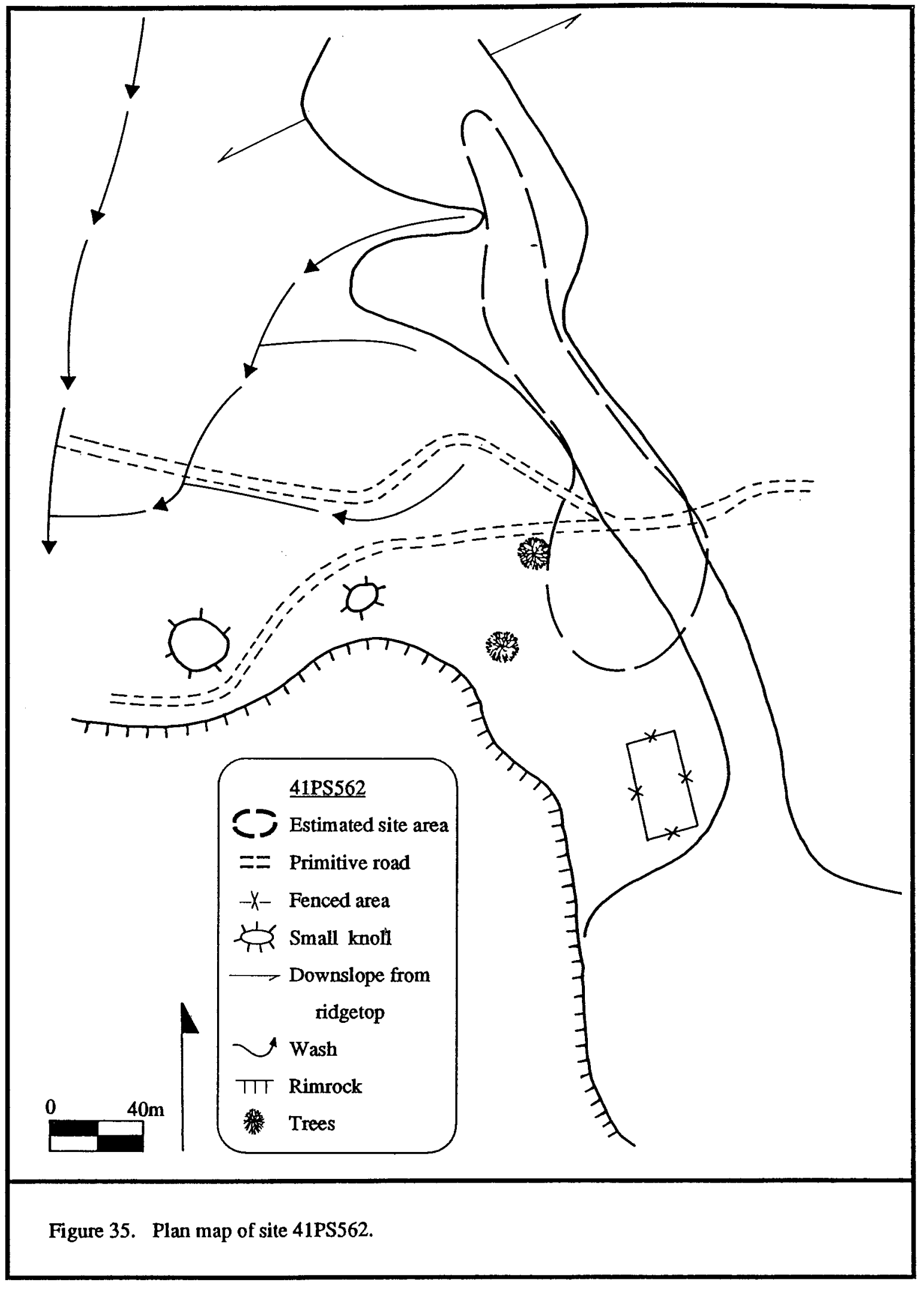




\title{
CHAPTER 5
}

\section{SITE ASSESSMENT AND RECOMMENDATIONS}

\author{
Site Assessment
}

An initial assessment of the National Register of Historic Places (NRHP) eligibility of each cultural property recorded during this survey was presented along with the description of the property in Chapter 4. This chapter is intended to present a more detailed discussion of the NRHP criteria and a summary of the assessments of each identified cultural resource property in relation to its potential for fulfilling these criteria.

Although full assessment of NRHP potential cannot be completed for all properties during this phase of investigation, each property may be evaluated in relation to the criteria set forth in 36 CFR 60.4. Of particular importance is the requirement that an archeological property nominated to the National Register of Historic Places be capable of yielding information important to our understanding of prehistory or history. In order to identify the types of information which may be considered important for this purpose, Alan Simmons (1989) lists a number of major research issues important for the archeology of central and western New Mexico and Trans-Pecos, Texas. While some of these are methodological in nature and others are specific to New Mexico, many are valid research topics for the Trans-Pecos area:

$\begin{array}{ll}\text { 1. } & \text { Pre-Paleo-Indian } \\ \text { 2. } & \text { Economy } \\ \text { 3. } & \text { The introduction of cultigens } \\ \text { 4. } & \text { The late bison hunters } \\ \text { 5. } & \text { Late Archaic/Early Formative } \\ \text { 6. } & \text { Archaic } \\ 7 . & \text { Chronology } \\ \text { 8. } & \text { Nontangible aspects of culture } \\ \text { 9. } & \text { Paleoenvironment } \\ \text { 10. } & \text { Small site archeology } \\ \text { 11. } & \text { Amount and nature of trade } \\ \text { 12. } & \text { Early Athabaskans } \\ \text { 13. } & \text { Contact period } \\ \text { 14. } & \text { Effects of introduced disease }\end{array}$

Thus, the first criteria of significance for any archeological property in the project area is its capability to yield information relevant to one of these research topics (Simmons 1989:213-214). In addition, the following criteria can also be applied to facilitate the evaluation of archeological resources:

1. potential for interpretation of culture history or local sequences;

2. potential for interpretation of intersite or intrasite patterning;

3. potential for interpretation of technology or primitive industries; and/or,

4. existence as a unique example of a site type.

In determining significance for archeological sites in the Van Horn project area, a number of criteria can be established for possible NRHP nomination based on the 14 research topics outlined above. The research topic of chronology is of primary importance since there has been very little work done in developing a local archeological sequence for the Van Horn area. Since Paleo-Indian occupations have been discovered near Van Horn, any site found during survey or monitoring containing artifacts dating to this period would be considered as having some significance. In general, sites within the project area 
which can be dated securely to any of the other following prehistoric periods would have the potential for being significant, as well. Early to Middle Archaic occupations would be considered initially important since very few sites dating to this time have been found in the Van Horn area overall. In the following Late Archaic and Late Prehistoric Periods, it is expected that many more sites dating to this time would be found in the project area. Therefore, other factors such as the integrity of the site deposit, quantity and quality of material, etc., would have to be taken into consideration in determining significance for these later kinds of prehistoric sites. In the historic era, there is very little chance of locating Spanish Exploration or Colonial Period sites in the project area. Nevertheless, there is the possibility that proto-historic or historic Native American occupations may be found in the project area. Since very little information is known about these particular kinds of occupations (especially in the interior Trans-Pecos area) such sites, if found, would be considered significant. Finally, there is always the chance of locating significant nineteenth or early twentieth century occupations and/or structures which might shed some additional light on the local history of the Van Horn area.

Other than chronology, issues concerning economy and technology would also be relevant topics since a majority of the prehistoric sites found seem to relate to primary lithic procurement activities such as quarrying and core reduction. This would, of course, be due to the availability of good quality chert which is plentiful in the project area. Nevertheless, more specific questions on intra or inter-site variability could be addressed based on different lithic reduction strategies which may be dependent on a number of factors including time period, location, quality and diversity of raw material, intensity of occupation, etc.

Whether or not specific properties exhibit such potential or contain data relevant to any particular research theme is dependent upon a precondition of contextual integrity of the archeological deposits. For example, a prehistoric site located close to an arroyo or a talus slope and buried by alluvial or colluvial sediments has a far greater potential for containing undisturbed deposits than one located on a stable, non-aggrading surface where the deposit has been heavily deflated. However, the nature of contextual integrity, as it affects research potential of a property, must also be viewed as being relative. That is to say, a property dating to the Paleo-Indian period need not demonstrate the same level of contextual integrity as one dating to the Late Prehistoric period in order to have the same, or greater, research potential and NRHP significance.

The survey and monitoring of the project area was designed to provide a preliminary assessment of:

1. the content (i.e., the range of artifactual and feature information available) of the cultural deposits;

2. the integrity of the deposits (i.e., is the site undisturbed, bioturbated, deflated, on bedrock, etc.); and,

3. the context of the cultural deposits in relation to both the natural and cultural environment of the appropriate time period.

\section{Results and Assessments}

The present survey resulted in the identification and recording of 31 previously unknown cultural resource sites, as well as noting the location of several recorded sites in the area (i.e., $41 \mathrm{HZ} 280$, 41CU9). The previously recorded sites, $41 \mathrm{HZ280}$ and 41CU9, are outside the area of impact of the road construction. Site 41CU9 is a National Register petroglyph site which is located well beyond the area of impact. Site 41HZ280, on the other hand, is immediately adjacent to the western end of White Tank Road. Unfortunately, the history of investigation and recordation of this site is unclear. Records at the Centennial Museum of the University of Texas at El Paso and the Texas Archeological Research Laboratory at the University of Texas at Austin are very limited and present no clear indications of the 
history of investigation or of the extent of the site. The most definitive records concerning the Mesquite Springs site (41HZ280) have been provided by Mr. Jack Hedrick of the El Paso Archeological Society.

Examination of the site area, which is located upslope from the western end of White Tank Road, indicated that test excavations (perhaps looter's holes) have been dug at some time in the past. However, neither Mr. Hedrick nor any of the universities in the area were aware of who had conducted such investigations. However, disturbance of the site is minimal and site $41 \mathrm{HZ} 280$ remains a significant prehistoric site within this region. Site $41 \mathrm{HZ} 280$ is a large multicomponent site with significant burned rock midden deposits. Diagnostic elements include two small triangular points, as well as El Paso Brownware, Jornada Brownware, and Mimbres Classic Black/White ceramics. Any future maintenance or construction activities should avoid this site.

All of the newly recorded sites date to the prehistoric era. Unfortunately, the majority of these sites also appear to be either surficial or have very shallow, deflated deposits. Establishment of a temporal association for these sites is extremely risky, since in most cases, no temporally diagnostic artifacts were observed during the survey. In only two cases could any estimate of site age be made. In the first instance, perusal of a local avocationalist's collection from site $41 \mathrm{CU} 488$ revealed four dart points, indicating an Archaic occupation. In the second case, one dart point (which was not relocated for later illustration) and one piece of El Paso Brownware were noted during survey on the surface of site 41CU496, indicating a Late Prehistoric and a possible Archaic occupation. However, even in these cases, there is no presently available means of determining how many other temporal periods are also represented at the sites, while the ages of the remaining 29 sites are totally unknown.

On the basis of what is presently known regarding the contexts of the 31 sites, 24 are considered to be unworthy of any further investigation and ineligible for nomination to the NRHP (Table 5). This evaluation was made because all but one of these sites were characterized by exposures of bedrock, indicating only shallow archeological deposits at best, while in most cases the material appeared to be entirely confined to the surface. The exception was 41JD147 which did not have any bedrock exposures; nevertheless, this site had an extremely thin archeological deposit with very few artifacts. The remaining seven sites (41CU487, 41CU488, 41CU492, 41CU493, 41CU496, 41PS561, 41PS562) are presently considered to be of "unknown eligibility" based on the field observations that they may contain areas with non-deflated archeological deposits. One site within this group (41CU496) also contained a feature.

In conclusion, it is recommended that all of the sites recorded in the Van Horn project area be protected from any further destruction caused by earth moving activities involving the road improvement plan initiated by the U.S. Border Patrol. If any of the sites with the status of unknown eligibility are to be affected by future road construction activities, then these particular sites should be tested to determine NRHP significance. 
Table 5

NRHP Assessment of Cultural Resource Sites for the JTF-6 Van Horn Road Repair Project, 1991

\begin{tabular}{|c|c|c|c|c|}
\hline Site & $\begin{array}{l}\text { Estimated } \\
\text { Average } \\
\text { Artifact } \\
\text { Density }^{1}\end{array}$ & $\begin{array}{l}\text { Contextual } \\
\text { Integrity }^{2}\end{array}$ & $\begin{array}{l}\text { NRHP } \\
\text { Assessment }\end{array}$ & Recommendations $^{3}$ \\
\hline $41 \mathrm{CU} 478$ & Low & Poor & Ineligible & No further work \\
\hline $41 \mathrm{CU} 479$ & Low & Poor & Ineligible & No further work \\
\hline $41 \mathrm{CU} 480$ & Low & Poor & Ineligible & No further work \\
\hline $41 \mathrm{CU} 481$ & Low & Poor & Ineligible & No further work \\
\hline $41 \mathrm{CU} 482$ & Low & Poor & Ineligible & No further work \\
\hline $41 \mathrm{CU} 483$ & Low & Poor & Ineligible & No further work \\
\hline $41 \mathrm{CU} 484$ & Very low & Poor & Ineligible & No further work \\
\hline $41 \mathrm{CU} 485$ & Low & Poor & Ineligible & No further work \\
\hline $41 \mathrm{CU} 486$ & Very low & Poor & Ineligible & No further work \\
\hline $41 \mathrm{CU} 487$ & Low & Good & Eligibility unknown & Testing \\
\hline $41 \mathrm{CU} 488$ & Low & Good & Eligibility unknown & Testing \\
\hline $41 C U 489$ & Low & Poor & Ineligible & No further work \\
\hline $41 \mathrm{CU} 490$ & Low & Poor & Ineligible & No further work \\
\hline $41 \mathrm{CU} 491$ & Extremely low & Poor & Ineligible & No further work \\
\hline 41CU492 & Low & Fair & Eligibility unknown & Testing \\
\hline 41CU493 & Very low & Fair & Eligibility unknown & Testing \\
\hline 41CU494 & Low & Poor & Ineligible & No further work \\
\hline 41CU495 & Very low & Poor & Ineligible & No further work \\
\hline $41 \mathrm{CU} 496$ & Low & Fair & Eligibility unknown & Testing \\
\hline $41 \mathrm{CU} 497$ & Low & Very poor & Ineligible & No further work \\
\hline 41CU498 & Low & Poor & Ineligible & No further work \\
\hline 41JD140 & Very low & Poor & Ineligible & No further work \\
\hline 41JD141 & Extremely low & Poor & Ineligible & No further work \\
\hline 41JD142 & Low & Poor & Ineligible & No further work \\
\hline 41JD143 & Very low & Poor & Ineligible & No further work \\
\hline 41.JD144 & Low & Poor & Ineligible & No further work \\
\hline 41JD145 & Very low & Poor & Ineligible & No further work \\
\hline 41JD146 & Extremely low & Poor & Ineligible & No further work \\
\hline 41JD147 & Extremely low & Poor & Ineligible & No further work \\
\hline 41PS561 & Low & Fair & Eligibility unknown & Testing \\
\hline 41PS562 & Very low & Good & Eligibility unknown & Testing \\
\hline
\end{tabular}


Table 5

(cont'd)

Key:

1. Criteria for density estimates:

$\underline{\text { Low }}=$ Average surface artifact density within the site area is one artifact per $5-40$ square meters.

Very Low $=$ Average surface artifact density within the site area is one artifact per 41100 square meters.

Extremely Low $=$ Average surface artifact density within the site area is one artifact per more than 100 square meters.

2. Criteria for levels of contextual integrity:

Good $=$ Moderate amount of human disturbance (i.e., road) with more than half of site intact. Although depth of deposit unknown, possibility does exist for buried material (based on lack of bedrock or location in aggrading environment). Features may also be present. Site subjected to wind and rain erosion.

$\underline{\text { Fair }}=$ Moderate amount of human disturbance (i.e., road) with less than half of site intact, or heavy amount of human disturbance (i.e., road and additional constructing and dozing) with more than half of site intact. Although depth of deposit unknown, possibility does exist for buried material (based on lack of bedrock or location in aggrading environment). Features may also be present. Site subjected to wind and rain erosion.

Poor $=$ Moderate to heavy amount of human disturbance (i.e., road), with more than half of site intact. Site has shallow or no depth to cultural deposits (based primarily on presence of bedrock exposures within site area). No features present. Site subjected to wind and rain erosion.

Very Poor $=$ Heavy amount of human disturbance (i.e., road), with more than half of site intact. Site has shallow or no depth to cultural deposits (based on presence of bedrock exposures within site area). No features present. Site subjected to wind and rain erosion.

3. Recommendations:

It should be noted that these recommendations only hold for the current Van Horn JTF- 6 Road Repair Project and are based on a finding of no additional effect to the sites from the current project. Additional activity in the area by JTF- 6 or any other agency may require testing of those sites to which the status "Eligibility unknown" has been assigned if those sites are to be impacted during subsequent activities. 



\section{REFERENCES}

Anderson, D.C. and E.S. Carter

1981 Archeological Investigations at Four Open Air Sites in Eastern El Paso, Texas. Paper presented to the second Jornada Mogollon Conference, Portales, New Mexico.

Andretta, A.A.

1976 A Single Site Complex on Alpine Creek and Its Implications: A Preliminary Report. In Transactions of the Eleventh Regional Archeological Symposium for Southeastern New Mexico and Western Texas, pp.35-51. Midland Archeological Society. Midland, Texas.

Banks, K.B.

1975 Prehistoric Settlement in the Three-Mile and Sulphur Draw Watersheds. Southern Methodist University, Archaeological Research Program, Research Report 82.

Bearden, S.

1977 Unpublished Notes on Evans Heans, an Old Timer Resident of Van Horn, Texas. Van Horn, Texas. Notes on file in Van Horn Project Files, Geo-Marine, Inc., Plano, Texas.

Betancourt, J.L.

1981 Preliminary Reconnaissance of Archeological Resources in the Southern Quitman Mountains. In Five Archeological Investigations in the Trans-Pecos Region of Texas, pp. 27-82. Texas Antiquities Permit Series No. 6. Texas Antiquities Committee, Austin.

Bousman, C.B. and M. Rohrt

1974 Archeological Reconnaissance of Big Bend National Park. Report prepared for the National Park Service. Archeology Research Program, Southern Methodist University. Dallas.

Bradford, J.E.

1980 Upper Dog Canyon Archeology, Guadalupe Mountains National Park, Texas. Southwest Cultural Resources Center, National Park Service, Santa Fe.

Campbell, T.N.

$1988 \quad$ Indians of Southern Texas and Northeastern Mexico, Selected Writings of Thomas Nolan Campbell. Texas Archeological Research Laboratory. University of Texas, Austin.

Cliff, M. and T. Fifield

1980 An Archeological Evaluation of the Floodwater Diversion in the Three-Mile and Sulphur Draw Watershed, Culberson County, Texas. Environmental Consultants, Inc., Dallas.

Coffin, E.F. 1932

Archeological Exploration of a Rock Shelter in Brewster County, Texas. Indian Notes and Monographs 48. Museum of the American Indian, Heye Foundation, New York.

Ford, R.I.

1977 Appendix E. Archeobotony of the Fort Bliss Maneuver Area II, Texas. In Settlement Patterns of the Eastern Hueco Bolson, by Michael E. Whalen, pp. 199-206. Report for the Corps of Engineers, Albuquerque District, by the El Paso Centennial Museum. Publications in Anthropology No. 4. El Paso Centennial Museum, University of Texas, Austin. 
Foster, M.S and J.C. Kelley

1987 Archeological Investigations of Portions of Eight Sites Within the Proposed Floodwater Diversion Three-Mile and Sulphur Draw, Three-Mile and Sulphur Draw Watershed. Culberson County, Texas. Jornada Anthropological Research Association, El Paso.

Fox, D.E.

1983 Traces of Texas History: Archeological Evidence of the Past 450 Years. Corona Publishing Company, San Antonio.

Gates, J.S., D.E. White, W.D. Stanley, and H.D. Ackermann

1980 Availability of Fresh and Slightly Saline Groundwater in the Basins of Westernmost Texas. Texas Department of Water Resources, Report 256.

Geo-Marine, Inc.

1989 Final Environmental Assessment Valentine Military Operations Area, Texas. Prepared for Tactical Air Command. Geo-Marine, Inc., Plano, Texas.

Gerald, R.E.

1978 Report on a Preliminary Archeological Survey of the Revised Location of a Floodwater Diversion in Three-Mile and Sulphur Creeks Watersheds, Culberson County, Texas. Report submitted to Soil Conservation Service, U.S. Department of Agriculture, Temple, Texas.

Gould, F.W.

1969 Texas Plants--A Checklist of Ecological Survey. Texas A\&M Agr. Ext. Stat. DUBL. MP-585.

Hedrick, J.A.

1968 Plateau Station Area Survey (EPAS-68). The Artifact 6(1):1-16.

1975 Archeology of the Plateau Site, Culberson County. The Artifact 13(4):45-82.

1986 Five Arrowpoint Types from the Plateau Complex, Van Horn, Texas. Transactions of the Twenty-Second Regional Archeological Symposium for Southeastern New Mexico and Western Texas:15-27.

1988 A Preliminary Report on Archeological Resources in Southern Culberson County in the Vicinity of Van Horn, Texas. Bulletin of the Texas Archeological Society, Vol. 59:129156.

Hicks, P.A.

1989 Environmental Context,Trans-Pecos; Regional Discussion, Trans-Pecos; Early Man in the Southwest, Trans-Pecos; The Unknown Archeology of the Southwest, Trans-Pecos; The Formative Period, Trans-Pecos, Archeological Considerations of the Historic Period, Trans-Pecos. In Human Adaptation and Cultural Change in the Greater Southwest, by A.H. Simmons, A.L. Wiener Stodder, D.D. Dykeman, and P.A. Hicks, pp. 35-38, 69-74, 113-118, 139-140. Arkansas Archeology Survey Research Series No. 32, Wrightsville.

Hinojosa, G.M.

1991 The Religious-Indian Communities: The Goals of the Friars. In Tejano Origins in Eighteenth-Century San Antonio, edited by G.E. Poyo and G.M. Hinojosa, pp. 61-84. University of Texas Press, Austin. 
Holden, W.C.

1938 Blue Mountain Rock Shelter. Bulletin of the Texas Archeological and Paleontological Society 10:208-221.

1941 Mackenzie Cave and Adjacent Sites in Pecos County. Bulletin of the Texas Archeological and Paleontological Society 13:46-57.

Howard, E.B.

1932 Caves Along the Slopes of the Guadalupe Mountains. Bulletin of the Texas Archeological and Paleontological Society 4:7-19.

Jackson, A.T.

1938 Picture-Writing of Texas Indians. Anthropological Papers Vol. II, and Study No. 27 of the Bureau of Research in the Social Sciences. University of Texas, Austin.

Jenkins, M.E. and A.H. Schroeder

1974 A Brief History of New Mexico. University of New Mexico Press, Albuquerque.

Katz, P.R.

1978 An Inventory and Assessment of Archeological Sites in the High Country of Guadalupe Mountains National Park, Texas. Center for Archeological Research, Archeological Survey Report 36. University of Texas, San Antonio.

Katz, P.R. and P.D. Lukowski

1981 Results of Archeological Survey in the Salt Flat Locality of Northern Hudspeth County, Texas. In Five Archeological Investigations in the Trans-Pecos Region of Texas, Texas Antiquities Committee, pp. 1-26. Texas Antiquities Committee Permit Series No. 6. Texas Antiquities Committee, Austin.

Kelley, J.C.

1952a Factors Involved in the Abandonment of Ceratin Peripheral Southwestern Settlements. American Anthropologist 54(3):356-387.

1952b The Historic Indian Pueblos of La Hunta de los Rios. New Mexico Historical Review 27(4):257-295.

1955 Juan Sabeata and Diffusion in Aboriginal Texas. American Anthropologist 57(5):981995.

1957 The Livermore Focus: A Clarification. El Palacio 64(1-2):44-52.

1986 Jumano and Patarabueye: Relations at La Hunta de los Rios. Anthropological Papers No. 77. Museum of Anthropology, University of Michigan, Ann Arbor.

Kelley, J.C., T.N. Campbell, and D.J. Lehmer

1940 The Association of Archeological Materials with Geological Deposits in the Big Bend Region of Texas. West Texas Historical and Scientific Society Publication 10:1-173.

Kirkland, F.

1937 A Study of Indian Pictures in Texas. Bulletin of the Texas Archeological and Paleontological Society 9:89-119. 
Lehmer, D.J.

1958 A Review of Trans-Pecos Texas Archeology. Bulletin of the Texas Archeological Society 29:109-144.

Lindsay, A.J.

1969 Current Research: Texas. American Antiquity 34(1):103.

Mallouf, R.J.

1981 Observations Concerning Environmental and Cultural Interactions During the Terminal Pleistocene and Early Holocene in the Big Bend of Texas and Adjoining Regions. Bulletin of the Texas Archeological Society 52:121-146.

1985 A Synthesis of Eastern Trans-Pecos Prehistory. Unpublished Master's Thesis. University of Texas, Austin.

1986 Prehistoric Cultures of the Northern Chihuahuan Desert. In Invited Papers from the Second Symposium on Resources of the Chihuahuan Desert Region, edited by J.C. Barlow, A.M Powell, and B.A. Timmermann, pp. 69-78. Chihuahuan Desert Research Institute, Sul Ross State University, Alpine, Texas.

Marmaduke, W.

1978 Prehistoric Cultures in Trans-Pecos Texas: An Ecological Explanation. Unpublished Ph.D. dissertation, Department of Anthropology, University of Texas, Austin.

Marmaduke, W. and H. Whitsett

1975 An Archeological Reconnaissance in the Central Davis Mountains, Texas. Natural Area Survey. Supplement of Part III of IV. Lyndon B. Johnson School of Public Affairs, University of Texas, Austin.

McMahan, C.A., R.G. Frye, and K.L. Brown

1984 The Vegetation Types of Texas, Including Cropland. (Illustrated Synopsis and Map). Wildlife Division, Texas Parks and Wildlife Department, Austin.

McNatt, L.

1981 An Archeological Reconnaissance of the Lower Pecos River. In Five Archeological Investigations in the Trans-Pecos Region of Texas, by the Texas Antiquities Committee, pp. 115-167. Texas Antiquities Committee Permit Series No. 6. Texas Antiquities Committee, Austin.

Mera, H.P

1938 Reconnaissance and Excavations in Southeastern New Mexico. Memoirs No. 51. American Anthropological Association, Washington, D.C.

Peter, D.E.

n.d. Archeological Background of Trans-Pecos Area Affected by the Valentine Military Operations Area. Ms. on file, Geo-Marine, Inc., Plano, Texas.

Pool, W.C., E. Triggs, and L. Wren

1975 A Historical Atlas of Texas. The Encino Press, Austin.

Poyo, G.E. and G.M. Hinojosa (eds.)

1991 Tejano Origins in Eighteenth-Century San Antonio. University of Texas Press, Austin. 
Quimby, B. and V.R. Brooks

1967 A Folsom Site Near El Paso, Texas. The Artifact 5(4):31-47. El Paso Archeological Society, El Paso.

Riley, C.L.

1987 The Frontier People: The Greater Southwest in the Protohistoric Period. Unpublished Ph.D. dissertation, University of Washington, Seattle.

Ruecking, F.

1953 The Economic System of the Coahuiltecans of Southern Texas and Northeastern New Mexico. Texas Journal of Science 6(3):480-497.

1955 The Social Organization of the Coahuiltecan Indians of Southern Texas and Northeastern New Mexico. Texas Journal of Science 7(4):357-388.

Sayles, E.B.

1935 An Archeological Survey of Texas. Medallion Papers No. 17. Gila Pueblo. Globe, Arizona.

1941 Infant Burial in Carrying Basket. Bulletin of the Texas Archeological and Paleontological Society 1:77-87.

Schmidly, D.J.

1977 Mammals of Trans-Pecos Texas. Texas A\&M Press, College Station and London.

Shackelford, W.J.

1955 Excavations at the Polvo Site in Western Texas. American Antiquity 20(3):256-262.

Shafer, H.J.

1977 Art and Territoriality in the Lower Pecos Region, Texas. Plains Anthropologist 22(75):13-22.

Simmons, A.H, A.L. Wiener Stodder, D.D. Dykeman, and P.A. Hicks

1989 Human Adaptation and Cultural Change in the Greater Southwest. Arkansas Archeological Survey Research Series No. 32, Wrightsville.

Skeels, L.L.M.

1972 An Ethnohistorical Survey of Texas Indians. Texas Historical Survey Committee, Archeological Report, No. 22.

Skinner, S.A. and C.B. Bousman

1973 Prehistoric Archeology in the Three-Mile and Sulphur Draw Watershed. Research Report 26, Archeological Research Program, Southern Methodist University, Dallas.

Smith, V.J.

1932 The Relation of the Southwestern Basketmaker to the Dry Shelter Culture of the Big

Bend. Bulletin of the Texas Archeological and Paleontological Society 4:55-62

1933 Sandals of the Big Bend Culture with Additional Notes Concerning Basketmaker Evidence. Bulletin of the Texas Archeological and Paleontological Society 5:57-65. 
1934 Hord Rock Shelter. Bulletin of the Texas Archeological and Paleontological Society 6:97-106.

1938 Carved Rock Shelter. Bulletin of the Texas Archeological and Paleontological Society 10:222-233.

Smith, V.J. and J.C. Kelley

1933 The Meriwether Rock Shelter, A Report on a Rock Shelter Excavation in the Big Bend of Texas. West Texas Historical and Scientific Society Circular 3.

Sommer, A.

19741973 SWFAS Early Man Conference. Transactions of the Ninth Regional Archeological Symposium for Southeastern New Mexico and West Texas, pp. 109-141. Midland Archeological Society. Midland, Texas.

Suhm, D.A., A.D. Krieger, and E.P Jelks

1954 An Introductory Handbook of Texas Archeology. Bulletin of the Texas Archeological Society 20 .

Taylor, W.W.

1964 Tethered Nomadism and Water Territoriality: An Hypothesis. Actas y Memorias del XXXV Congreso Internacional de Americanistas, 1962:197-203.

Tyler, R.C.

1975

The Big Bend: A History of the Last Texas Frontier. U.S. Department of the Interior, Washington, D.C.

Whalen, M.E.

1981. An Investigation of Pithouse Village Structure in Western Texas. Journal of Field Archeology 8(3):303-311.

Wylie, R.L.

1973 History of Van Horn and Culberson County, Texas. Pioneer Book Publishers, Inc. Hereford, Texas. 
APPENDIX A

Curated Material from JTF-6 Van Horn 

The materials from this investigation are to be curated at the Texas Archeological Research Laboratory, The University of Texas at Austin. The following list of items enumerates the materials to be curated at this facility under Delivery Order No. 12 of Contract No. DACA63-90-D-0061.

1. One copy of the Scope of Work.

2. Two copies of the Final Report.

3. Original field and laboratory notes, maps, and records.

4. Two copies of each site form.

5. Black-and-white photographs and catalog.

6. Color slides and catalog. 

JTF-6 Van Horn Attachment 1

Access to this data is limited. Please contact U.S. Army Corps of Engineers, Fort Worth District for further information. 



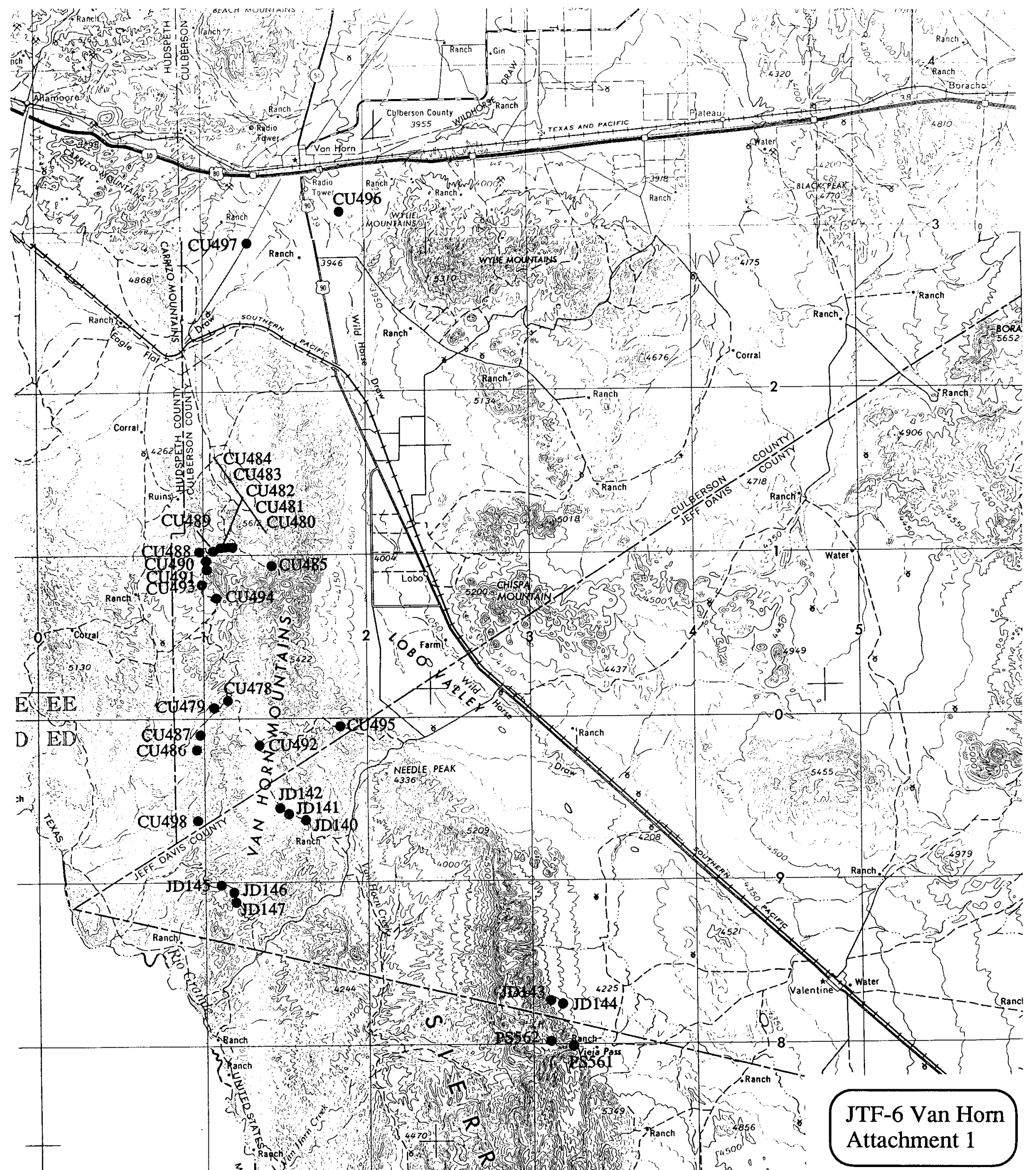

Scale 1:250,000 
